UNIVERSIDADE DE SÃO PAULO

FFCLRP - DEPARTAMENTO DE FÍSICA

PROGRAMA DE PÓS-GRADUAÇÃO EM FÍSICA APLICADA À MEDICINA E BIOLOGIA

\title{
Desenvolvimento de um aptassensor para detecção de Dengue
}

Bassam Bachour Júnior

Dissertação apresentada à Faculdade de Filosofia, Ciências e Letras de Ribeirão Preto da USP, como parte das exigências para a obtenção do título de Mestre em Ciências, Área: Física aplicada à Medicina e Biologia

Ribeirão Preto - SP 


\author{
Universidade de SÃo Paulo \\ FFCLRP - DEPARTAMENTO DE FÍsica
}

BASSAM BACHOUR JÚNIOR

Desenvolvimento de um aptassensor para detecção de Dengue

Ribeirão Preto - SP

2020 


\section{BASSAM BACHOUR JÚNIOR}

\section{Desenvolvimento de um aptassensor para detecção de Dengue}

Dissertação apresentada à Faculdade de Filosofia, Ciências e Letras de Ribeirão Preto da Universidade de São Paulo, como parte das exigências para a obtenção do título de Mestre em Ciências.

Área de Concentração:

Física Aplicada à Medicina e Biologia.

Orientador:

Prof. Dr. Marcelo Mulato.

Versão corrigida

Versão original disponível na FFCLRP-

Ribeirão Preto - SP

2020 
Autorizo a reprodução e divulgação total ou parcial deste trabalho, por qualquer meio convencional ou eletrônico, para fins de estudo e pesquisa, desde que citada a fonte.

\title{
FICHA CATALOGRÁFICA
}

\author{
Bachour Júnior, Bassam \\ Desenvolvimento de um aptassensor para detecção de \\ Dengue / Bassam Bachour Júnior; orientador Prof. Dr. Marcelo \\ Mulato. Ribeirão Preto - SP, 2020. \\ 113 f.:il. \\ Dissertação (Mestrado - Programa de Pós-graduação em Física \\ Aplicada à Medicina e Biologia) - Faculdade de Filosofia, Ciências \\ e Letras de Ribeirão Preto da Universidade de São Paulo, 2020. \\ 1. Biossensor. 2. Dengue. 3. Aptâmero. 4. Espectroscopia de \\ Impedância Eletroquímica.
}


Nome: Bachour Júnior, Bassam

Título: Desenvolvimento de um aptassensor para detecção de Dengue

Dissertação apresentada à Faculdade de Filosofia, Ciências e Letras de Ribeirão Preto da Universidade de São Paulo, como parte das exigências para a obtenção do título de Mestre em Ciências.

Aprovado em:

\section{Banca Examinadora}

Prof. Dr. :

Instituição:

Julgamento:

Assinatura:

Prof. Dr. :

Instituição:

Julgamento:

Assinatura:

Prof. Dr. :

Instituição:

Julgamento:

Assinatura: 
Dedicado de todo meu coração à memória de minha querida avó

\section{Maria Martins Cardoso Claro}

que sempre acreditou que seus netos conseguiriam seguir a carreira do ensino superior mas não pode nos agraciar com sua presença neste momento.

Sua ausência sempre será sentida. 


\section{AGRADECIMENTOS}

Todos que participaram deste projeto de forma individual dando sugestões ou ajudando, sempre terão minha gratidão.

Não tenho palavras para agradecer ao meu orientador Prof. Dr. Marcelo Mulato, que depositou em mim sua confiança. Principalmente pelos conselhos e dádivas de sua vasta experiência e sabedoria.

Eu agradeço profundamente à Profa. Dra. Marina Ribeiro Batistuti que sempre acompanhou comigo minha carreira acadêmica, desde à iniciação científica até hoje e nunca desistiu de mim, sempre com aquela paciência e perseverança para ensinar e falar aquela frase: "Bassam, vamos ter que voltar para a bancada!"

Não posso deixar de agradecer à minha amada Raquel Pantojo de Souza por todo apoio emocional e todo encorajamento para atingir meus sonhos da vida acadêmica. Sem você, não teria descoberto minha verdadeira paixão pela pesquisa.

A todos os meus amigos e colegas de laboratório em Ribeirão Preto, Murilo Callil Faleiros, Hugo José Nogueira Pedroza Dias Mello, Ricardo Estéfani França Rocha, Gustavo Daniel Martinez Madeira e Lucas Matiola de Souza que sempre tiveram aquela paciência comigo, principalmente "Bassam, o cronômetro!!". Dentre os que já passaram pelo grupo, minha gratidão para Guilherme de Oliveira Silva e Fernando Mano. Meus agradecimentos especiais à minha irmãzinha de laboratório Daísy Ferreira Camargo, por aceitar batalhar conosco na busca pela pesquisa e conhecimento. Todos vocês contribuíram imensamente para meu crescimento, de forma que me tornei o que sou hoje.

À Profa. Dra. Elisa Maria de Sousa Russo e à Mestra Aline Sanches Pereira da Faculdade de Ciências Farmacêuticas de Ribeirão Preto pela excelente contribuição intelectual e o empenho na tentativa de expressar as proteínas a serem 
utilizadas neste trabalho, meus mais sinceros agradecimentos.

Aos técnicos Jaqueline Passaglia, Marcílio Mano e Carlos Renato, agradeço por sua colaboração e paciência no decorrer deste projeto. A secretária do programa FAMB Nilza Marina Leone Marino agradeço por todo o auxílio e paciência ao longos desses anos.

Gostaria de expressar minha gratidão pela CAPES e pela FAPESP pelo todo suporte financeiro no projeto.

Do Curso de Física Médica da Faculdade de Filosofia, ciências e Letras de ribeirão preto, meus agradecimentos aos docentes e amigos, especialmente Guilherme Pilotto Fernandes, Jaqueline Ramos, Matheus Telka Golçalves e a todos que fizeram minha vida mais feliz nesses anos.

Minha mais profunda e eterna gratidão aos meus pais Bassam Bachour e Áurea Cardoso Claro Bachour que passaram o seu sonho do ensino superior para seus filhos e deram todo seu sangue e apoio para essa realização. Ao meu irmão Rhamy Salim Bachour e meus familiares, saibam que todos possuem um lugar eterno em meu coração.

Por fim e se não o mais importante, todas as honras e glória à Deus. 


\section{RESUMO}

\section{BACHOUR JR., B. Desenvolvimento de um aptassensor para detecção de}

Dengue. 2020. 113 f. Dissertação (Mestrado - Programa de Pós-graduação em Física Aplicada à Medicina e Biologia) - Faculdade de Filosofia, Ciências e Letras de Ribeirão Preto, Universidade de São Paulo, Ribeirão Preto - SP, 2020.

Entre as doenças negligenciadas estão as transmitidas pelo vírus pertencentes à família Flaviviridae, do gênero Flavivírus, causador da Dengue. Este é responsável pela produção de 7 proteínas, dentre elas a proteína não estrutural 1 (NS1), a única secretada e encontrada nos estágios iniciais da doença em fluidos biológicos, o que a transformou em um interessante biomarcador. Neste trabalho será abordado o desenvolvimento de um biossensor para detecção de NS1 utilizando, para isto, aptâmeros de DNA como elementos de reconhecimento biológico. Os aptâmeros são cadeias de DNA artificiais, quimicamente estáveis, com grande flexibilidade e com habilidade de "folding", para interagirem com alvos específicos. Para tanto, eletrodos de ouro foram funcionalizados por meio da co-imobilização de aptâmeros e 6-mercapto-1-hexanol (MCH), para análises impedânciométricas e aptâmeros com 6-ferrocenyl-hexanethiol (FCC), para as capacitivas, formando em ambos casos uma monocamada auto-organizada (SAM). A caracterização e deteç̧ão foram realizadas por meio das técnicas de espectroscopia de impedância eletroquímica (EIE) e da espectroscopia de capacitância eletroquímica (ECE), bem como de análises morfológicas via microscopia de força atômica (AFM). A plataforma sensível foi otimizada em função da densidade de recobrimento dos aptâmeros, assim como as soluções utilizadas. O limite de detecção foi obtido a partir da curva analítica para diferentes soluções contendo NS1 pelas técnicas: EIE, 1,29 e 1,22 pg/mL, e ECE, 121,8 e 6,24 pg/mL, em tampão e soro humano comercial sem diluição, 
respectivamente. Estas medidas apresentaram uma boa sensibilidade para ambas técnicas de: EIE, 2,9 e 2,7 \% por década, e ECE, 3 e 4 nF por década, em tampão e soro comercial, respectivamente; bem como um alto grau de seletividade da NS1 em comparação com outras biomoléculas da Dengue como a DENV-E. Com isso, o aptassensor é capaz de detectar NS1 na faixa clínica e apresenta potencial para o desenvolvimento de uma nova classe de dispositivos miniaturizados point-in-care.

Palavras-chave: 1. Biossensor. 2. Dengue. 3. Aptâmero. 4. Espectroscopia de Impedância Eletroquímica. 


\section{ABSTRACT}

BACHOUR JR., B. Development of an aptasensor for Dengue detection. 2020. 113 f. Dissertation (M.Sc. - Postgraduate program in Physics Applied to Medicine and Biology) - Faculty of Philosophy, Sciences and Literature, University of São Paulo, Ribeirão Preto - SP, 2020.

Among neglected diseases there is the one transmitted by Flaviviridae virus family, at gender Flavivírus, responsible for Dengue disease. This virus is responsible for 7 proteins production, including the non-structural (NS1), only secreted in the early stages of the disease on biological fluids, what makes it an interesting biomarker. In this work be report the develop of a biosensor for NS1 detection, using DNA aptamers as biological recognition element. Aptamers are an artificial DNA sequence, chemically stable, with high flexibility and ability to folding for connection with specific target. Gold electrodes were functionalized by co-immobilization of aptamers and 6-mercapto-1-hexanol (MCH) for impedimetric analysis and aptamers with 6-ferrocenyl-hexanethiol (FCC) for the capacitive, making a self -assembly monolayer (SAM) in both cases. The characterization and detection were performed by electrochemical impedance spectroscopy (EIS), electrochemical capacitance spectroscopy (ECS), and atomic force microscopy (AFM). The platform was optimized as a function of the coating density of the aptamers and the solutions. The limit of detection was derived from the analytical curve for different NS1 solutions by: EIS, 1.29 and $1.22 \mathrm{pg} / \mathrm{mL}$, and ECS, 121.8 and $6.24 \mathrm{pg} / \mathrm{mL}$, in buffer and undiluted commercial human serum, respectively. These measurements presented a good sensibility for the both techniques: EIS, 2.9 and $2.7 \%$ per decade, and ECS, 0.003 and $0.004 \mu \mathrm{F}$ per decade, in buffer and commercial serum, respectively. The aptasensor shows a high level of selectivity to detect NS1 in 
comparison with other Dengue biomolecules, such as DENV-E. Furthermore, the aptasensor was capable to detect NS1 in clinical range and it is a promising candidate to develop a new class for miniaturized point-of-care devices.

Key-words: 1. Biosensor. 2. Dengue. 3. Aptamer. 4. Eletrochemical Impedance Spectroscopy. 


\section{LISTA DE FigURAS}

1.1 Distribuição global das doenças relacionadas ao Flavírus. Fonte: Holbrook, 2017.[1] . . . . . . . . . . . . . . . 2

1.2 Genoma do vírus da dengue. Fonte: adaptado de Guzman et al., 2010

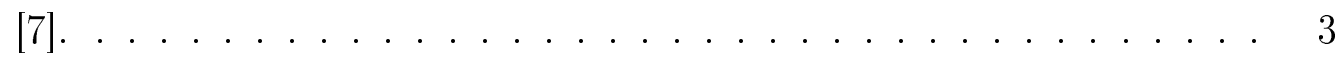

1.3 Concentração de NS1 e antígeno no organismo com os dias de acordo com incidência: a) 1a. infecção; b) 2a. infecção. A área destacada indica o período na qual há o máximo de NS1 no sangue. Fonte: adaptada de Blacksell et al., 2012. [20] . . . . . . . . . . 5

2.1 Representação esquemática do funcionamento dos biossensores que devem possuir: um biomarcador; uma forma de detecção conhecida; uma transdução desse sinal; um display para ilustrar os dados adquiridos. Fonte: adaptada de Scheller et al., 2001 [37]. . . . . . . . 11

2.2 Perfil de concentração da adsorção acumulativa de espécies. Em x $=0$ corresponde à interface eletrodo/solução, a partir deste ponto as propriedades do eletrólito são constantes e correspondem às mesmas presentes no interior da solução. Fonte: adaptada de Ticianelli et al., 2013 [48]. . . . . . . . . . . . . . . . . . . 13

2.3 Processos de adsorção de espécies: a) interação inicialmente fraca; b) interação forte; c) formação da dupla camada. Fonte: adaptada de Ticianelli et al., 2013 [48]. . . . . . . . . . . . . . . 16

2.4 Ilustração de uma célula eletroquímica. . . . . . . . . . . . . . . . 16

2.5 Tipos de ondas periódicas: a) triangular; b) senoidal. Fonte: adaptada de Bard et al., 1980 [51]. . . . . . . . . . . . . . . 18 
2.6 Representação ilustrativa da impedância real (Z') e imaginária (Z'). Fonte: adaptada de Bard et al., 1980 [51]. . . . . . . . . . . . 20

2.7 a) Representação gráfica da impedância de um circuito RC em série conforme mostra a equação 2.24 ; b) circuito equivalente utilizado para a modelagem dos dados. Fonte: adaptada de Bard et al., 1980 [51]. . 21

2.8 a) Representação gráfica da impedância de um circuito $\mathrm{RC}$ em paralelo conforme mostra a equação 2.24 ; b) circuito equivalente utilizado para a modelagem dos dados. Fonte: adaptada de Bard et al., 1980 [51]. . . . . . . . . . . . . . . . . . . . 23

2.9 Ilustração do modelo referente à interface eletroquímica: a) circuito equivalente de Randles e b) diagrama de Nyquist com o ajuste do circuito equivalente. $\mathrm{R}_{s}$ representa a resistência da solução; $\mathrm{R}_{c t}$ representa a resistência à transferência de carga; CPE representa a capacitância da dupla camada elétrica e W representa a impedância de warburg. Fonte: adaptada de Góes et al., 2012 [54]. . . . . . . . 24

2.10 Ilustração a) Todos sistema eletroquímico em uma célula de três eletrodos e os processos envolvidos; b) circuito elétrico equivalente do sistema. . . . . . . . . . . . . . . . 25

2.11 Ilustração do 6-(ferrocenil)hexanotiol com o átomo de ferro (Fe) confinado. . . . . . . . . . . . . . 26

2.12 Diagramas obtidos para as plataformas: impedânciométrica (a, c) sem e com cargas confinadas respectivamente; Capacitiva (b, d) na ausência e na presença de cargas confinadas respectivamente. . . . . . 28

2.13 Ilustração do sinal de potencial pelo tempo presente na voltametria cíclica. Fonte: adaptado de Yuan et al., 2010 [55]. . . . . . . . . . 28

2.14 Representação gráfica de um voltamograma (corrente vs potencial) de um processo reversível redox na voltametria cíclica. Fonte: adaptado de Yuan et al., 2010 [55]. . . . . . . . . . . . . . . 29

2.15 Representação esquemática do funcionamento do microscópio de força atômica. Fonte: adaptado de Ferreira et al., 2006 [61] . . . . . . . . . 31 
2.16 Ilustração dos três modos de funcionamento da AFM: contato (linha superior); não contato (linha inferior); intermintente (linha intermediária). Fonte: adaptado de Oliveira et al., 2012 [62]. . . . . . 31

2.17 Configurações de aptâmeros: a) ligação simples com micromolécula; b) ligação simples com macromoléculas; c) ligação dupla ou sanduíche com macromolécula; d) sanduíche com um aptâmero e um anticorpo. Fonte: adaptada de Song et al., 2008 [64]. . . . . . . . . . . . . 33

3.1 Ilustração da organização e estrutura dos alcanotióis na superfície do ouro. Fonte: adaptado de Thévenot et al., 2001 [50]. . . . . . . . . 36

3.2 Ilustração da formação da superfície auto organizada composta por MCH e aptâmero em um eletrodo de ouro. . . . . . . . . . . 36

3.3 Curva obtidas dos processos de limpeza dos eletrodos de ouro: a) dessorção eletroquímica; b) limpeza eletroquímica. Ambos perfis cíclicos foram obtidos com uma velocidade de varredura de $100 \mathrm{mV} / \mathrm{s}$. $\quad 39$

3.4 Processos de montagem da SAM. Tratamento térmico do aptâmero $\left(95^{\circ} \mathrm{C}\right.$ e em seguida $\left.4{ }^{\circ} \mathrm{C}\right)$; Diluição do aptâmero e do $\mathrm{MCH}$ na solução de imobilização; Depósito da solução para a co-imobilização. . . . . . 40

3.5 Etapas de limpeza após as 16-18 horas. Adição das soluções de limpeza 1, 2, e 3. Backfilling com MCH. Estabilização da SAM em tampão PBS para a subsequente realização das medidas. . . . . . . . 41

3.6 Variação da resistência à transferência de carga em função da concentração de NS1. O círculo (aberto e fechado) representa o uso do tampão Imob, variando a forma de refrigeração do aptâmero (freezer e temperatura ambiente respectivamente - T. Amb); Os triângulos (abertos e fechados) representam o uso do tampão SELEX, e a mesma variação da forma de enovelamento do aptâmero. As linhas (contínuas e tracejadas) não representam um ajuste, mas são apenas uma forma de guia para o leitor. . . . . . . . . . . . . . . 42 
3.7 Variação da resistência à transferência de carga em função da concentração de NS1 para os dois métodos propostos. O quadrado aberto representa o aquecimento do aptâmero por 10 minutos seguido pelo resfriamento por 40 minutos e pela diluição no tampão SELEX. O círculo fechado representa o mesmo aquecimento, porém já diluindo no tampão SELEX e aguardando os 40 minutos para estabilizar. As linhas tracejadas não representam o ajuste, sendo apenas um guia. . . 44

3.8 Variação de transferência à carga em função do valor de $\mathrm{pH}$ do tampão PBS. As linhas abertas representam a $\Delta \mathrm{R}_{c t}(\%)$ para a NS1 à $1 \mu \mathrm{g} / \mathrm{mL}$ e os quadrados abertos representam a mesma variação para a NS1 à $100 \mathrm{ng} / \mathrm{mL}$. As linhas tracejadas e contínuas são apenas um guia, não representado qualquer modelo matemático. . . . . . . . . . . 45

3.9 Variação da resistência à transferência de carga em função da concentração de NS1 diluída nos tampões: fosfato salino - PBS pH 7,4 (coluna branca com linhas agrupadas); binding - BB pH 7,5 (coluna vermelha com linhas dipersas). . . . . . . . . . . . 46

3.10 Variação de $\mathrm{R}_{c t}(\%)$ em função da concentração de NS1 diluída em: tampão binding (BB) com BSA (quadrado aberto); e tampão BB sem a adição de BSA (círculo fechado). A linha pontilhada preta representa uma regressão linear do sistema com a adição de BSA. A linha pontilhada vermelha representa a mesma forma de regressão, porém com o sistema sem BSA. . . . . . . . . . . . . 47

3.11 Resposta da $\Delta \mathrm{R}_{c t}(\%)$ em função da concentração de NS1 para os dois sistemas montados: a) superfície montada MCH e NS1 diluída em BSA $+\mathrm{BB}$ - quadrado fechado e superfície montada com $\mathrm{MCH}$, bloqueada com BSA e com NS1 diluída em PBS +BSA (círculo fechado); b) SAM montada com aptâmero + MCH e NS1 em PBS+BSA (quadrado fechado) e SAM com bloqueio de BSA e NS1 em PBS+BSA (círculo fechado). As linhas tracejadas e contínuas não representam qualquer operação matemática sendo apenas um guia. 49 
3.12 Imagem de microscopia de força atômica de um eletrodo de ouro em diferentes etapas: (a) limpo e modificado com MCH (b) em uma resolução macro $(2,5$ x 2,5 $\mu \mathrm{m})$; (c) limpo e modificado com $\mathrm{MCH}$ (d) em um resolução micro $(1,0 \times 1,0 \mu \mathrm{m})$; (e) Formação da SAM e (f) SAM com bloqueio de BSA e $1 \mu \mathrm{g} / \mathrm{mL}$ de NS1. . . . . . . . . 51

4.1 Variação da resistência à transferência de carga $\left(\Delta \mathrm{R}_{c t}(\%)\right)$ em função das proporções (aptâmero : total tiol) para a concentração de 100 $\mathrm{pg} / \mathrm{mL}$ de NS1. . . . . . . . . . . . . . . . . . . 54

4.2 Resultados proveniente das técnicas: a) voltametria cíclica com a representação dos potenciais de oxidação (Oxi) e redução (Red), a linha tracejada representa um guia do potencial inicial ao final; b) espectroscopia de impedância eletroquímica para os potenciais de OCP (quadrado fechado) e potencial $\mathrm{E}_{\text {in }}$ (círculo fechado). . . . . . 55

4.3 Aumento do $\Delta \mathrm{R}_{c t}(\%)$ em função da concentração de NS1 para três meios: PBS(linha azul pontilhada); Soro + PBS (50\%) (linha vermelha tracejada); Soro $100 \%$ (linha preta contínua). . . . . . . 57

4.4 Controle negativo. Comparações de $\Delta \mathrm{R}_{c t}(\%)$ em função da NS1 e da proteína E. ....................... 60

5.1 Representação esquemática dos (a) Ângulos de fase em função da frequência obtidos pela EIS; (b) dados de capacitância obtidos para diferentes concentrações de NS1 (10 pg para $1 \mu \mathrm{g} / \mathrm{mL}) . \quad$. . . . . 63

5.2 Variação na capacitância $(-\Delta C)$ em função das concentrações de NS1 para as duas formas distintas de co-imobilização e backfilling: Aptâmero + FCC com backfilling de $\mathrm{MCH}$ (quadrados pretos e abertos); Aptâmero + MCH com backfilling de FCC (círculo aberto e vermelhos). As linhas pretas e tracejadas não são um ajuste, são um guia. *Os erros foram obtidos pelo desvio padrão das amostras e, devido à sua grandeza não houve como apresentá-los no gráfico . . . . 65 
5.3 Resultados do (a) Voltamograma cíclico da SAM com FCC e aptâmeros, (I) $1^{\circ}$ ciclo, (II) o $10^{\circ}$ ciclo. A taxa de varredura foi de $50 \mathrm{mV} / \mathrm{s}$ em PBS (pH 7,4); (b) Variação na capacitância $(-\Delta \mathrm{C})$ em função das concentrações de NS1 para os potenciais de circuito aberto (OCP) (quadrado vermelho sólido) e o de meia onda $\left(\mathrm{E}_{p / 2}\right)$ (quadrado preto aberto). . . . . . . . . . . . 67 67

5.4 Variação de $-\Delta \mathrm{C}(\mathrm{nF})$ em função das densidades de superfícies (1:10, 1:50, 1:100, 1:150, e 1:200) para $100 \mathrm{pg} / \mathrm{mL}$ de NS1. As linhas em vermelho no meio das colunas se referem aos erros estatísticos de cada concentração e proporção. . . . . . . . . . . . . . 6 68

5.5 Variação da capacitância $-\Delta \mathrm{C}(\mathrm{nF})$ em função das concentrações de NS1 em tampão. . . . . . . . . . . . . . . . . . 69

5.6 Variação da capacitância $-\Delta \mathrm{C}(\mathrm{nF})$ em função das concentrações de NS1 em soro comercial humano 100\%. A linha tracejada representa a regressão linear. Em detalhe, a linha contínua representa o modelo de Hill para os mesmos dados. . . . . . . . . . . . . 70

5.7 Controle negativo. Variação do $-\Delta \mathrm{C}(\mathrm{nF})$ em função da proteína alvo: NS1 e a proteína E em uma concentração de $1 \mathrm{ng} / \mathrm{mL}$ diluídas em soro. 71

B.1 Imagens do sistema montado: Eletrodo de trabalho (a); Célula eletroquímica (b); Plataforma de detecção (c) . . . . . . . . . . . . 90

B.2 Diagrama de Nyquist e o ajuste do circuito de Randles para a construção da curva analítica da EIE. . . . . . . . . . . . . . . . 90 


\section{LISTA DE TABELAS}

1.1 Sensibilidade e especificidade de dispositivos comerciais para detecção de IgM e NS1 com disposititivos como ELISA e de detecção rápida. 6

1.2 Limites de deteç̧ão das diferentes formas de transdução que possuem como alvo a proteína NS1 ou o anticorpo IgM. . . . . . . . . 7

3.1 Resultados da rugosidade aritmética $\left(\mathrm{R}_{a}\right)$ para cada etapa desenvolvida no eletrodo de ouro. . . . . . . . . . . . . . . . . . . . 52

4.1 Parâmetros obtidos pela regressão linear e pelo cálculo do limite de detecção para a EIE. . . . . . . . . . . . . . . 58

4.2 Dados de diferentes técnicas para detecção de NS1 nos últimos 5 anos. 59

5.1 Parâmetros obtidos pela regressão linear e pelo cálculo do limite de detecção para a ECE. . . . . . . . . . . . . . . . . . 69

A.1 Resultados dos parâmetros obtidos pela AFM para cada etapa desenvolvida no eletrodo de ouro . . . . . . . . . . . . . 887

B.1 Resultados dos parâmetros do circuito de Randles obtidos para a curva analítica da EIE. . . . . . . . . . . . . . 89 


\section{LISTA DE ABREVIATURAS}

AC Corrente alternada

AFM Microscopia de força atômica

BB Tampão de ligação ou binding buffer

BSA Proteína de soro bovino

CGS Teoria Gouy-Chapman-Stern

CPE Elemento de fase constante

DC Corrente contínua

DENV Dengue

EDTA Ácido etilenodiamino tetra-acético

ECE Espectroscopia de capacitância eletroquímica

EIE Espectroscopia de impedância eletroquímica

ELISA Exame de imunofluorescência

FCC 6-(Ferrocenyl)hexanethiol

IgG Anticorpo G

$\operatorname{Ig}$ Anticorpo M

IHP Plano interno de Helmholtz

Imob Tampão de imobilização 
LoD Limite de detecção

MCH 6-mercapto-hexano

NS1 Proteína não estrutural 1

OCP Potencial de circuito aberto

OHP Plano externo de Helmholtz

OMS Organização Mundial da Saúde

PB Tampão fosfato

PBS Tampão fosfato salino

RSS Soma dos quadrados do resíduo

SAM Monocamada auto organizada

TE Tampão tris com EDTA

VC Voltametria cíclica

YFV Vírus da febre amarela 


\section{Lista De Símbolos}

$\begin{array}{ll}\mathrm{A}_{g} & \text { Área } \\ \mathrm{A}_{r} & \text { Área geométrica } \\ \mathrm{A}_{r} & \text { Área real } \\ \mathrm{C}^{*} & \text { Capacitância } \\ \mathrm{C}^{\prime} & \text { Capacitância complexa } \\ \mathrm{C}^{\prime \prime} & \text { Capacitância real } \\ \mathrm{C}_{D} & \text { Capacitância de difusão } \\ \mathrm{C}_{d l} & \text { Capacitância da dupla camada } \\ \mathrm{C}_{H} & \text { Capacitância de Helmholtz } \\ \mathrm{C}_{m} & \text { Capacitância modificada } \\ \mathrm{C}_{s} & \text { Capacitância da solução } \\ \mathrm{d} & \text { Distância entre as placas } \\ \mathrm{E}_{1 / 2} & \text { Diferença de potencial } \\ \mathrm{E}_{f} & \text { Potencial de meia onda reversível } \\ & \text { Canal } \\ & \text { Canda irreversível } \\ & \text { Capal }\end{array}$




\begin{tabular}{|c|c|}
\hline $\mathrm{E}_{i}$ & Potencial inicial \\
\hline $\mathrm{E}_{o x i}$ & Potencial de oxidação \\
\hline $\mathrm{E}_{\text {red }}$ & Potencial de redução \\
\hline $\mathrm{F}$ & Constante de Faraday \\
\hline $\mathrm{f}_{r}$ & Frequência \\
\hline $\mathrm{I}_{c}$ & Corrente do capacitor \\
\hline $\mathrm{I}_{m}$ & Amplitude máxima da onda senoidal \\
\hline $\mathrm{I}_{p}$ & máxima corrente de oxidação \\
\hline $\mathrm{I}_{o x i}$ & Corrente de oxidação \\
\hline $\mathrm{I}_{\text {red }}$ & Corrente de redução \\
\hline h & Coeficiente de Hill \\
\hline $\mathrm{k}$ & Constante de Michaelis \\
\hline $\mathrm{n}$ & Número de elétrons transferidos pelo processo de difusão \\
\hline $\mathrm{R}^{2}$ & Ajuste linear quadrado \\
\hline $\mathrm{R}$ & Resistência \\
\hline $\mathrm{R}_{a}$ & Rugosidade aritmética \\
\hline $\mathrm{R}_{c t}$ & Resistência à transferência de carga \\
\hline $\mathrm{R}_{\text {gas }}$ & Constante de gás ideal \\
\hline $\mathrm{R}_{q}$ & Rugosidade quadrática média \\
\hline $\mathrm{R}_{s}$ & Resistência da solução eletrolítica \\
\hline $\mathrm{R}_{t}$ & Rugosidade total \\
\hline $\mathrm{R}_{v}$ & Profundidade máxima \\
\hline
\end{tabular}




\begin{tabular}{|c|c|}
\hline $\mathrm{R}_{y}$ & Rugosidade máxima \\
\hline $\mathrm{t}$ & Tempo \\
\hline $\mathrm{T}$ & Temperatura \\
\hline $\mathrm{v}$ & Velocidade \\
\hline $\mathrm{V}$ & Tensão ou potencial \\
\hline $\mathrm{V}_{c}$ & Potencial do capacitor \\
\hline $\mathrm{V}_{m}$ & Amplitude da onda senoidal do potencial aplicado \\
\hline W & Impedância de Warburg \\
\hline$[X]$ & Concentração do analito alvo \\
\hline $\mathrm{Z}$ & Impedância complexa \\
\hline Z' & Impedância real \\
\hline Z" & Impedância imaginária \\
\hline $\mathrm{Z}_{c}$ & Impedância do capacitor \\
\hline $\mathrm{Z}_{r}$ & Impedância do resistor \\
\hline $\mathrm{Z}_{T R C}$ & Impedância total \\
\hline$-\Delta \mathrm{C}$ & Variação da capacitância \\
\hline$\Delta \mathrm{C}_{m x}$ & Ponto máximo de variação da capacitância \\
\hline$\Delta \mathrm{C}_{\min }$ & Ponto mínimo de variação da capacitância \\
\hline$\Delta \mathrm{E}$ & Variação de potencial \\
\hline$\Delta \mathrm{R}_{c t}$ & Variação da resistência à transferência de carga \\
\hline$\varepsilon$ & Permissividade absoluta do meio \\
\hline$\varepsilon_{0}$ & Permissividade do vácuo \\
\hline
\end{tabular}


xxiii

$\varepsilon_{r} \quad$ Permissividade relativa do meio

$\theta \quad$ Ângulo de fase para o potencial

$\sigma$

Desvio padrão das medidas

$\phi \quad$ Angulo de fase para a corrente

$\omega$

Frequência angular 


\section{SUMÁRIO}

Lista de Figuras $\quad$ xi

Lista de Tabelas $\quad$ xvii

Lista de Abreviaturas $\quad$ xviii

Lista de Símbolos $\quad$ xx

1 Introdução 1

1.1 Dengue . . . . . . . . . . . . . . . . . . 1

1.2 Técnicas de detecção de Dengue . . . . . . . . . . . . 5

1.3 Objetivos deste estudo . . . . . . . . . . . . . . . . . 8

1.3 .1 Geral ....................... 8

$1.3 .2 \quad$ Específicos . . . . . . . . . . . . . 8

1.4 Visão geral da dissertação . . . . . . . . . . . . . . . . . . 8

2 Teoria \& Princípios 10

2.1 Biossensores . . . . . . . . . . . . . . . . . 10

2.1.1 Biossensores eletroquímicos . . . . . . . . . . . 13

2.1.1.1 Modelo da dupla camada elétrica . . . . . . . . 13

2.1.1.2 Célula eletroquímica . . . . . . . . . . . 15

2.1.2 Técnicas eletroquímicas de caracterização . . . . . . . . 17

2.1.2.1 Espectroscopia de Impedância Eletroquímica . . . . 17

2.1.2.2 Espectroscopia de Capacitância Eletroquímica . . . . 25

2.1.2.3 Voltametria cíclica . . . . . . . . . . . . 27

2.1.3 Microscopia de Força Atômica . . . . . . . . . . . . . . . 30 
2.2 Aptâmeros . . . . . . . . . . . . . . . . 32

3 Fabricação, Otimização e Caracterização do Biossensor 35

3.1 Fabricação . . . . . . . . . . . . . . . 35

3.1.1 Monocamada auto-organizada com aptâmeros . . . . . . 35

3.1 .2 Materiais .................... 37

3.1.3 Processo de limpeza do eletrodo . . . . . . . . . . . 37

3.1.4 Preparo do Aptâmero . . . . . . . . . . . . . 39

3.1 .5 Instrumentação . . . . . . . . . . . . . . 40

3.2 Otimização . . . . . . . . . . . . . . . . . 41

3.2.1 Tampão de imobilização e preparação do aptâmero .... . 41

3.2.2 Diluição do aptâmero após aquecimento . . . . . . . . . 43

3.2 .3 Preparo da proteína NS1 . . . . . . . . . . . 44

3.2.3.1 pH do tampão PBS . . . . . . . . . . . 44

3.2.3.2 Tipos de Tampão . . . . . . . . . . . . . 45

3.2.3.3 Uso do BSA na Solução . . . . . . . . . . 46

3.2.4 Estabilização da SAM . . . . . . . . . . . . 48

3.3 Caracterização por AFM . . . . . . . . . . . . . 50

4 Biossensor Impedânciométrico $\quad 53$

4.1 Espectroscopia de Impedância Eletroquímica . . . . . . . . . . . . . . 53

4.2 Otimização da proporção entre aptâmero e MCH . . . . . . . . . . 54

4.3 Potencial aplicado - OCP vs $\mathrm{E}_{\text {in }} \ldots \ldots \ldots \ldots 5$

4.4 Curva Analítica . . . . . . . . . . . . . . . 56

4.5 Controle Negativo . . . . . . . . . . . . . . . 60

4.6 Conclusões Parciais . . . . . . . . . . . . . . . 60

5 Biossensor Capacitivo $\quad 62$

5.1 Espectroscopia de capacitância eletroquímica . . . . . . . . . . 62

5.1 .1 Funcionalização da SAM . . . . . . . . . . . 63

5.2 Potencial aplicado - OCP vs $\mathrm{E}_{1 / 2} \ldots \ldots \ldots \ldots$

5.3 Otimização da proporção entre aptâmero e FCC . . . . . . . . 66

5.4 Curva analítica ......................... 67 
xxvi

5.5 Controle Negativo . . . . . . . . . . . . . . . 71

5.6 Conclusões parciais . . . . . . . . . . . . . . 71

6 Conclusões gerais $\quad 73$

$\begin{array}{ll}\text { Referências } & 75\end{array}$

$\begin{array}{ll}\text { A Microscopia de Força Atômica } & 87\end{array}$

B Circuito Elétrico Equivalente $\quad 88$ 


\section{CApÍtulo}

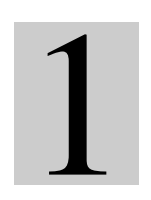

\section{INTRODUÇÃO}

Neste capítulo é apresentado o contexto histórico e epidemológico da Dengue, bem como sua forma de transmissão e expressão da proteína não estrutural 1 (NS1) no sangue. Além disto, serão abordados tópicos sobre as diferentes técnicas de detecção atualmente. Por fim, serão abordados os objetivos do presente trabalho e uma visão geral da dissertação.

\subsection{Dengue}

Dentre os diversos tipos de doenças que ameaçam a saúde do ser humano no mundo, como diabetes, HIV, influenza, ebola, etc, existem aquelas que são causadas por Flaviviroses (família Flaviviridae; gene Flavivírus). Tais doenças são associadas às infecções em mamíferos, constituindo de dois grupos principais de vírus: às que são causadas por carrapatos e às que são transmitidas por mosquitos. Dentre esses vírus, os que são transmitidos por mosquitos são considerados os mais diversificados, e podem ser divididos de acordo com o tipo de mosquito transmissor: os Culex spp. [portador do vírus serocomplexo da encefalite japonesa e outras doenças de cunho neurológico]; os Aedes spp. [portador do vírus da Febre Amarela, do inglês Yellow Fever (YFV), da Dengue (DENV) e muitos outros associados a doenças viscerotrópicas ou hemorrágicas] [1]. A título de ilustração, a Figura 1.1 apresenta a distribuição dessas doenças ao redor do mundo de acordo com os Centros de Controle e Prevenção e a Organização Mundial de Saúde (OMS, do inglês World Health Organization).

Dentre essas doenças supracitadas, a YFV e a dengue foram as primeiras a 


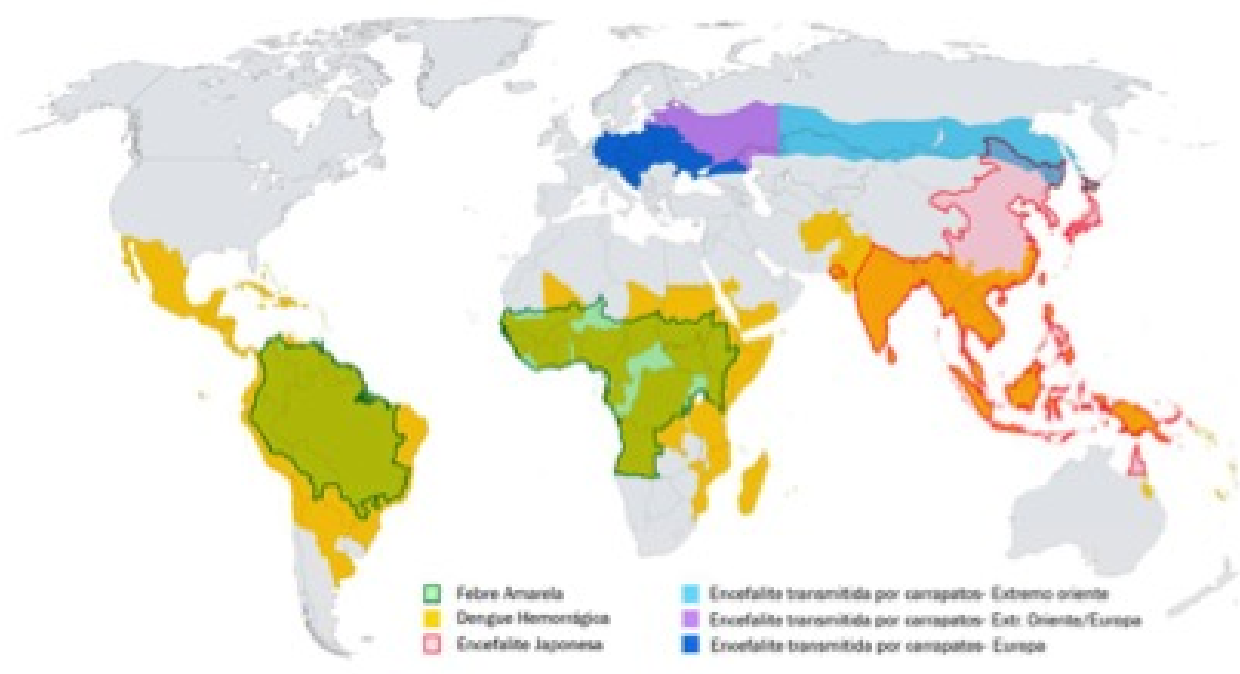

Figura 1.1: Distribuição global das doenças relacionadas ao Flavírus. Fonte: Holbrook, 2017.[1]

serem estudadas em 1902 e 1907, respectivamente. Em 1906, a primeira catalogação do ciclo de transmissão da dengue foi publicada por Bancoft[2], levantando a hipótese de o Aedes aegypti ser o vetor da infecção, sendo confirmado posteriormente por Agramonte e outros pesquisadores [2], o que estabeleceu um elo epidemiológico da transmissão do tipo:

Mosquito infectado $\rightarrow$ homem susceptível $\rightarrow$ homem infectado $\rightarrow$ mosquito infectado

Após intensivos estudos, em 1943 ocorre o primeiro isolamento do vírus da Dengue [3]. Em 1945, Sabin e Schlesinger isolaram outro vírus da Dengue que possuía características antigênicas diferentes, mas em regiões diferentes das anteriores. Essa decoberta determinou que a Dengue possuía sorotipos diferentes (DENV-1 e DENV-2, respectivamente). Em 1956, após uma epidemia de Dengue hemorrágica no sudeste asiático, encontrou-se mais dois sorotipos (DENV-3 e DENV-4), definindo os 4 sorotipos conhecidos atualmente [2] capazes de gerar a infecção [4]. O número de casos de Dengue informados anualmente à OMS aumentou, assim, de 0,4 para 1,3 milhões na década de 1996-2005, atingindo 2,2 milhões em 2010 e 3,2 milhões em 2015 [5]. Só em 2013 por exemplo, foram registradas 3,2 milhões de casos severos e 9 mil mortes ao redor do mundo [6].

Nas Américas, o único transmissor desse vírus é o mosquito Aedes aegypti, 
originário da África subsaariana onde, com o avanço da globalização e da industrialização das cidades, acabou se domesticando e se adaptando ao novo ambiente criado pelo homem. Como fruto dessa expansão, suas larvas se tornaram abundantes nas cidades e, assim, capazes de serem levadas para outras áreas pelos meios de transporte. Sua proliferação é mais acentuada em regiões de climas tropicais e subtropicais [7].

Os sintomas gerados pelos DENVs variam de acordo com a idade e o estado imunológico do paciente. É possível ver essas diferenças em crianças na infecção primária que desenvolvem um estado febril leve, enquanto adultos apresentam um alto grau de febre, cefaléia intensa, dor nas articulações, gosto metálico, diarréia, vômito e dor de estômago entre outros sintomas [7, 8, 9]. A infecção do mesmo indivíduo por sorotipo distintos faz com que o paciente desenvolva uma infecção secundária da Dengue, modificando assim toda a fisiopatologia da doença. Em crianças, tais infecções podem evoluir para uma síndrome de permeabilidade vascular aguda conhecida como síndrome do choque da Dengue. Em adultos, essa infecção secundária evolui a Dengue um tipo mais severo capaz de provocar hemorragias conhecida como Dengue hemorrágica [7].

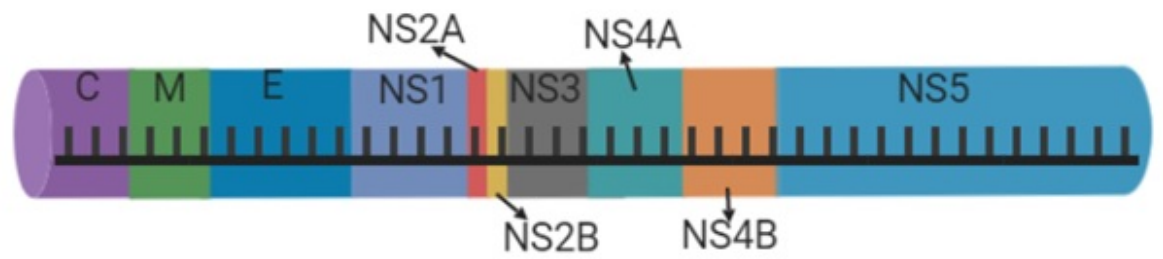

Figura 1.2: Genoma do vírus da dengue. Fonte: adaptado de Guzman et al., 2010 [7].

O vírus da Dengue é composto por uma cápsula esférica de 40 a $50 \mathrm{~nm}$ de diâmetro envolto por uma camada de material lipopolissacarídeo. O genoma da Dengue (Figura 1.2), em forma de fita simples, possui aproximadamente $11 \mathrm{~kb}$ de comprimento, sendo capaz de codificar três proteínas estruturais: as glicoproteínas da cápsula $(\mathrm{C})$, da membrana $(\mathrm{M})$ e do envelope (E); e mais sete proteínas não-estruturais (NS1, NS2A, NS2B, NS3, NS4A, NS4B e NS5) [2, 6, 10, 11]. Destas proteínas, a NS1 de destaca por ser uma glicoproteína de aproximadamente 46 kDa, com 12 resíduos de cisteína, e desempenha papel de vital importância para 
a viabilidade do vírus $[12,13]$, sendo a única proteína encontrada no sangue durante a infecção [10, 14]. Após estudos sobre a atuação das glicoproteínas, constatou-se que as proteínas estruturais são responsáveis por proteger o vírus e entregar o RNA para a célula hospedeira, enquanto as proteínas não-estruturais organizam produção de um novo vírus na célula hospedeira $[11,15]$.

Essas descobertas chamaram a atenção dos pesquisadores no estudo da concentração de NS1 no organismo dos pacientes, sendo encontrado quantidades expressivas da NS1 nos primeiros dias de infecção e permanecendo por até 9 dias nos pacientes. Essa característica é observada também na infecção secundária da doença $[16,17]$. Durante a monitoração desta proteína pelo exame de imunoflorescência (ELISA), foi possível quantificar a concentração de NS1 no sangue. Os indivíduos apresentaram de 0,04 a $2 \mu \mathrm{g} / \mathrm{mL}$ e 0,01 a $2 \mu \mathrm{g} / \mathrm{mL}$ para as infecções primárias e secundárias, respectivamente [11]. Outros estudos apontam uma concentração máxima de $50 \mathrm{ng} / \mathrm{mL}$, estando, portanto, dentro do limiar descrito anteriormente $[12,17]$. Como os pacientes procuram um atendimento médico nos estágios iniciais da doença devido à febre alta, levantou-se a possibilidade da utilização desta proteína como forma de detecção da doença nestes estágios [16, 18].

Além da detecção da glicoproteína NS1, alguns estudos começaram a analisar outros compostos que poderiam ser utilizados como diagnóstico da doença. Entre eles, a detecção dos anticorpos imunoglobina G ( $\operatorname{IgG}$ ) e imunoglobina M (IgM) [19]. Esses anticorpos agem como resposta natural do organismo ao invasor e são produzidos alguns dias após a contaminação (via picada). A concentração destes anticorpos atinge seu máximo entre o $6^{\circ}$ e o $8^{\circ}$ dia (Figura 1.3)[17, 20].

Os anticorpos IgG e IgM garantem a imunidade vitalícia ao infectado, caso este receba novamente o mesmo sorotipo. Durante a infecção secundária com outro sorotipo, o organismo passa a produzir novamente os dois anticorpos. Porém, com diferentes concentrações, dado que a imunoglobina $\mathrm{G}$ combate os antígenos do grupo flavírus como um todo, enquanto a imunoglobina $\mathrm{M}$ combate os antígenos do sub-tipo do vírus [19].

Com o avanço da tecnologia em técnicas de biosensoriamento, a detecção tanto dos anticorpos quanto das proteínas tornou-se possível através de técnicas ópticas, piezoelétricas, e eletroquímicas [12]. 

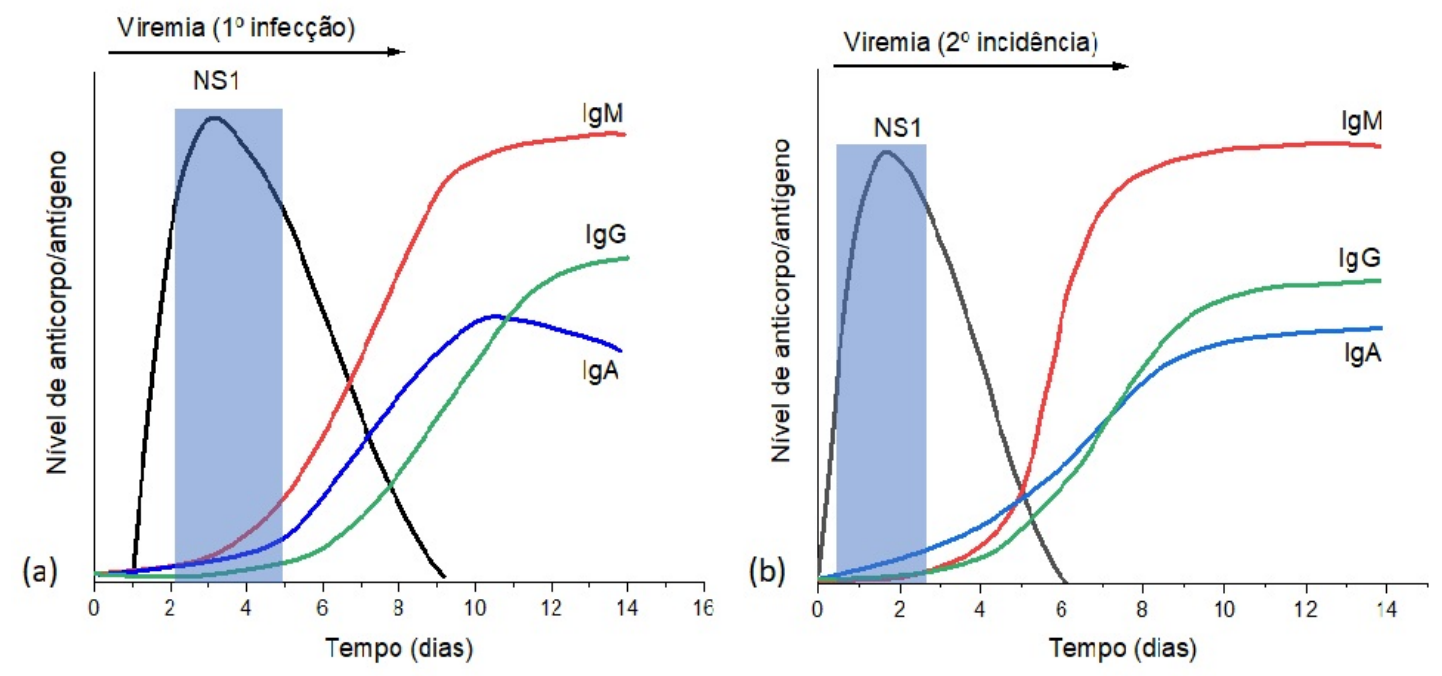

Figura 1.3: Concentração de NS1 e antígeno no organismo com os dias de acordo com incidência: a) 1a. infeç̧ão; b) 2a. infecção. A área destacada indica o período na qual há o máximo de NS1 no sangue. Fonte: adaptada de Blacksell et al., 2012. [20]

\subsection{Técnicas de detecção de Dengue}

Atualmente, a confirmação da Dengue pode ser realizada por de dois métodos, a saber:

I - Método convencional:

- Cultura do vírus (considerada padrão ouro) [21] que demanda um longo tempo para incubação e a confirmação da doença (7-12 dias) [12];

- Amplificação dos ácidos nucléicos pela reação em cadeia polimerase em tempo real (RT-PCR) que é capaz de diferenciar os sorotipos de vírus, porém necessita de equipamentos de alto custo [11, 20];

- Diagnóstico sorológico, que utiliza anticorpos para a deteç̧ão e possui vantagem de ser utilizada em climas tropicais com baixo custo. Sua desvantagem está na sua alta reatividade cruzada (um anticorpo reage com mais de um antígeno) em regiões endêmicas, podendo gerar confusão com outros Flavivírus presentes no local [11, 21];

- Detecção dos anticorpos IgG e IgM pela ELISA, que possui um alto grau de especificidade e sensibilidade (Tabela 1.1). Entretanto necessita de técnicos 
devidamente treinados e equipamento de alto custo [11, 22];

- Deteçã̃o da aglutinação de glóbulos vermelhos nos envelopes da proteína da Dengue (antigo padrão ouro). Como o infectado não possui essa aglutinação devido aos anticorpos, é possível medir a inibição dos glóbulos vermelhos. Sua grande desvantagem é presença de uma alta reatividade cruzada $[6,11,15]$.

A Tabela 1.1 apresenta resumidamente os parâmetros encontrados para os testes comerciais.

Tabela 1.1: Sensibilidade e especificidade de dispositivos comerciais para detecção de IgM e NS1 com disposititivos como ELISA e de detecção rápida.

\begin{tabular}{l|ccccc}
\hline \multirow{2}{*}{ IgM } & Teste & Marca & Sens. (\%) & Esp. (\%) & Ref. \\
\cline { 3 - 6 } & ELISA & Pathozyme M Dengue & 83,5 & 86,5 & {$[23]$} \\
& & SD Dengue IgM Capture & 84,9 & 97,3 & {$[20]$} \\
& \multirow{2}{*}{ Teste } & Panbio Dengue Duo Cassette & 77,8 & 90,6 & {$[23]$} \\
& Rápido & SD Bioline Dengue IgG/IgM & 87,3 & 86,8 & {$[24]$} \\
\hline \multirow{2}{*}{ NS1 } & ELISA & DENV Detect NS1 & 95,9 & 100 & {$[23]$} \\
& & SD Dengue NS1 Ag & 76,7 & 98,3 & {$[24]$} \\
& \multirow{2}{*}{ Teste } & Dengue NS1 Detect & 86 & 100 & {$[25]$} \\
& Rápido & SD Dengue Duo & 72,4 & 73,4 & {$[26]$} \\
\hline
\end{tabular}

II - Método de biossensoriamento:

Visando o desenvolvimento de dispositivos baratos, com alta sensibilidade, fabricação simples e com a possibilidade de miniaturização, os pesquisadores passaram a desenvolver técnicas baseadas em biossensoriamento, ou seja, a interação do analito biológico com o receptor confinado no dispositivo de sensoriamento gera um sinal bioquímico quantificável (na maior parte das vezes, elétrico). A transdução do sinal biológico da Dengue vem sendo testada por meio de três tipos principais:

- Dispositivos piezoelétricos. O transdutor utilizado é um cristal que ressoa numa uma frequência natural, sendo mudada apenas com o depósito de massa (proteína, anticorpo) no sensor. Essa mudança altera a frequência de vibração natural, gerando um sinal elétrico (pelo efeito piezoelétrico)[6, 27]. 
- Sensores ópticos, onde a transdução de sinal se baseia na reação do alvo com a superfície do dispositivo, gerando um sinal fluorescente que é captado pelo detector óptico. Por apresentar alta seletividade, sensibilidade e detecção em tempo real, o dispositivo ganhou atenção dos pesquisadores [11, 28].

- Dispositivos eletroquímicos. Estes por sua vez, utilizam os sinais de corrente gerados após as reações de oxidação e redução do sistema eletroquímico. A ligação do receptor alvo com o receptor causa uma mudança no dispositivo, modificando a intensidade do sinal de corrente gerado [11, 27].

A Tabela 1.2 mostra alguns limites de detecção para as diferentes transduções citadas acima.

Tabela 1.2: Limites de deteç̧ão das diferentes formas de transdução que possuem como alvo a proteina NS1 ou o anticorpo IgM.

\begin{tabular}{c|cccc}
\hline Alvo & Transdução & LoD & Meio & Ref. \\
\hline \multirow{2}{*}{ NS1 } & Eletroquímico & $0,33 \mathrm{ng} / \mathrm{mL}$ & Soro humano & {$[29]$} \\
& & $0,12 \mathrm{ng} / \mathrm{mL}$ & Soro humano & {$[30]$} \\
& & $0,09 \mu \mathrm{g} / \mathrm{mL}$ & $*$ & {$[16]$} \\
& \multirow{2}{*}{ Piezoelétrico } & $0,74 \mu \mathrm{g} / \mathrm{mL}$ & Soro humano & {$[31]$} \\
& & $1-10 \mu \mathrm{g} / \mathrm{mL}$ & Sangue & {$[32]$} \\
& & $0,05 \mu \mathrm{g} / \mathrm{mL}$ & $*$ & {$[33]$} \\
\hline \multirow{2}{*}{ ggM } & \multirow{2}{*}{ Óptico } & $1: 10^{6} \mathrm{diluição}$ & Soro humano & {$[25]$} \\
& \multirow{4}{*}{$*$} & $12 \mathrm{pg} / \mathrm{mm}{ }^{2}$ & Plasma sanguíneo & {$[34]$} \\
\hline & \multirow{4}{*}{ Valores não apresentados. }
\end{tabular}

Como o presente estudo tem como base o desenvolvimento de dispositivo para biossensoriamento, o próximo capítulo trará mais detalhes sobre os biossensores e suas categorias, bem como seu impacto na ciência. 


\subsection{Objetivos deste estudo}

\subsubsection{Geral}

Desenvolver um biossensor utilizando aptâmeros de DNA para detecção de Dengue.

\subsubsection{Específicos}

- Desenvolver uma metodologia para construção de biossensor com aptâmero de DNA;

- Caracterizar e otimizar o biossensor via técnicas impedânciométricas;

- Caracterizar o biossensor via microscopia de força atômica;

- Modificar a monocamada do biossensor para utilização de medidas de capacitância;

- Determinar a sensibilidade e o limite de detecção para cada metodologia;

- Detectar a proteína em tampão e em soro humano comercial.

\subsection{Visão geral da dissertação}

Esta dissertação foi dividida em seis capítulos e aqui está apresentado uma breve descrição de cada um. O Capítulo 2 irá abordar os conceitos teóricos sobre biossensores, os modelos da dupla camada elétrica e sobre a célula eletroquímica. Será introduzida uma revisão das principais técnicas eletroquímicas: espectroscopia de impedância eletroquímica, a espectroscopia de capacitância eletroquímica e a voltametria cíclica. Este capítulo ainda aborda uma pequena revisão sobre a microscopia de força atômica, e ao final, serão descritas as características dos aptâmeros.

Toda a fabricação, otimização e caracterização do biossensor serão descritos no Capítulo 3, incluindo: limpeza do eletrodo, preparo do aptâmero envolvendo os tampões e formas de diluição do mesmo. Nesse capítulo serão mostradas as otimizações necessárias para a funcionalidade da proteína alvo: tipos de tampões, pH 
e o uso de BSA na estabilização da NS1. Por fim, será mostrada uma caracterização da superfície pela microscopia de força atômica.

A otimização da técnica impedimétrica será descrita no Capítulo 4, incluindo as densidades de superfícies de cada monocamada montada para as diferentes proporções entre aptâmero e o espaçador utilizado e o tipo de potencial a ser aplicado na espectroscopia de impedância eletroquímica. A obtenção dos limites de detecções e o controle negativo apresentado neste capítulo representam o estudo da real performance do dispositivo.

O Capítulo 5 aborda os conceitos e a metodologia necessária para a funcionalização da monocamada na técnica capacitiva. Além disto, serão abordados os processos de otimização desta técnica, incluindo: formas de imobilização da molécula de ferroceno, o tipo de potencial a ser aplicado nesta plataforma, a densidade de superfície do aptâmero e do ferroceno. A obtenção dos respectivos limites de detecção e controle negativo finalizam a caracterização do modelo capacitivo.

As conclusões finais desta dissertação serão apresentadas no Capítulo 6 . 


\section{Capítulo}

\section{TEORIA \& PRINCÍPIOS}

O Capítulo 2 irá abordar sobre a definição de biossensores e o uso da trandução eletroquímica. Além disto, será descrito toda teoria eletroquímica sobre funcionamento dos biossensores eletroquímicos, como a dupla camada elétrica e o uso da célula eletroquímica. Após estes tópicos, o capítulo apresentará as técnicas eletroquímicas que serão abordadas neste trabalho, como: Espectroscopia de Impedância Eletroquímica; Espectroscopia de Capacitância Eletroquímica; Voltametria Cíclica e a técnica topográfica de Microscopia de Força Atômica. Por fim, o capítulo irá expor o uso dos aptâmeros como receptores da proteína NS1.

\subsection{Biossensores}

O conceito de biossensor surgiu em 1906, quando M. Cremer demonstrou que a concentração de ácido em um líquido é proporcional a um potencial elétrico que surge entre as partes opostas de uma membrana de vidro mergulhada no fluido [34, 35]. Tal fenômeno foi explicado posteriormente em 1909 com o conceito de pH (concentração de íons de hidrogênio em uma solução). Após essa descoberta, inúmeros cientistas tentaram desenvolver dispositivos para detectar diferentes moléculas. Em 1956 surge o primeiro biossensor com a detecção do oxigênio por Leland C. Clark, recebendo o título de "pai dos biossensores"[36]. Após essas descobertas, o campo de biossensoriamento ganhou uma grande atenção por parte dos pesquisadores. De acordo com a base de dados "Web of Science", é possível encontrar a indexação de mais de 34 mil trabalhos só entre o período de 2005 a 2019. 
O dispositivo de Leland proporcionou uma expansão no ramo de biossensores, já que alguns pesquisadores começaram a detectar não só moléculas, mas elementos maiores como células. Essa evolução fez com que a união internacional de química pura e aplicada propusesse uma definição mais rigorosa sobre a definição de biossensores: "um biossensor é um dispositivo integrado autônomo capaz de fornecer informações analíticas quantitativas ou semi-quantitativas específicas usando um elemento de reconhecimento biológico (receptor bioquímico) que está em contato espacial direto com um elemento transdutor"[36, 37]. A Figura 2.1 mostra uma representação esquemática dessa definição.

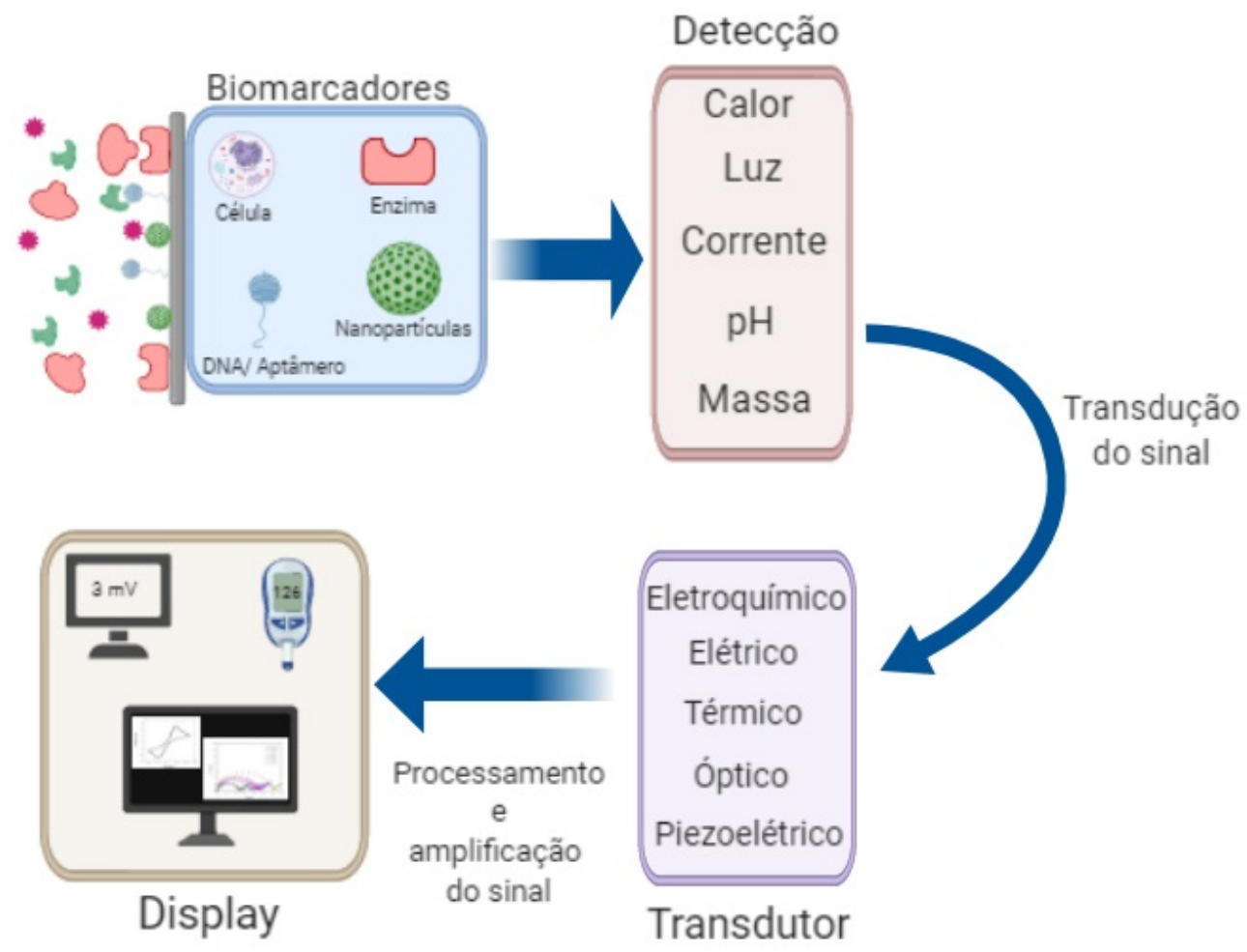

Figura 2.1: Representação esquemática do funcionamento dos biossensores que devem possuir: um biomarcador; uma forma de deteç̧ão conhecida; uma transdução desse sinal; um display para ilustrar os dados adquiridos. Fonte: adaptada de Scheller et al., 2001 [37].

Conforme ilustrado na Figura 2.1, os receptores bioquímicos (ou biomarcadores) abrangem biomoléculas que possuem grande importância ao organismo humano, dentre elas:

- As enzimas: esses sensores se aproveitam da grande especificidade das enzimas 
com um substrato, gerando um produto. O biossensor enzimático mais conhecido é de glicose oxidase, utilizado hoje em dia para medir o índice glicêmico [38, 39];

- As células: são usadas principalmente pela capacidade de detectar a condição do microambiente intra e extracelular, parâmetros fisiológicos e respostas pelas interações entre estímulo e células. [40, 41];

- Os anticorpos: como descrito anteriormente, são biomoléculas capazes de se ligar a apenas os antígenos alvos específicos [42, 43];

- O DNA/RNA: são fitas de oligonucleotídeos capazes de reconhecer e se ligar com a sua parte complementar (hibridização) pela formação de pontes de hidrogênios estáveis [44, 45].

Além dos tipos de transdução já descritos no capítulo anterior (piezoelétrico, óptico e eletroquímico), os biossensores podem ser caracterizados com:

- magnética: capazes de detectar micro e nanopartículas em canais microfluídicos pelo efeito de magnetoresistência [42];

- térmica: dispositivos que exploram as propriedades de absorção e ou produção de calor, alterando assim, a temperatura no meio no qual está inserido [46];

- íons: utilizam materiais semicondutores sensíveis a íons, sofrendo uma mudança em seu potencial elétrico na superfície na presença do mesmo [46].

Analisando todos os parâmetros supracitados, é possível concluir que toda a tecnologia envolta aos biossensores tem como objetivo explorar propriedades únicas desse evento de reconhecimento biológico, convertendo o sinal obtido em uma saída facilmente legível pelo usuário. Tal característica trouxe e traz pesquisadores de diferentes áreas da ciência e engenharia para unir suas habilidades, abrindo novas fronteiras na pesquisa científica. 


\subsubsection{Biossensores eletroquímicos}

Dos tipos de transdução citados nas seções anteriores, o atual trabalho tem como foco o uso do modelo eletroquímico. O principal objetivo dessa escolha é devido aos grandes avanços que essa área está proporcionando à sociedade nos últimos anos com técnicas com alto grau de simplicidade e baixo custo.

A eletroquímica aborda o estudo das reações químicas rápidas (espontâneas) capazes de produzir corrente elétrica, bem como o estudo da utilização da corrente elétrica para induzir alguma reação química (não-espontânea). O uso desta corrente permite a transferência dos elétrons de uma superfície para o meio eletrolítico (oxidação), enquanto simultaneamente, ocorre a transferência dos elétrons livres da solução para uma outra região da superfície (redução). Esse sistema é visto como um ciclo, representando um circuito eletroquímico [47].

\subsubsection{Modelo da dupla camada elétrica}

Um metal em contato com uma solução eletrolítica pode possuir dois processos de transferência de elétrons. O processo próximo a superfície é governado por forças anisotrópicas, enquanto do meio eletrolítico é governado por forças isotrópicas, ou seja, nas regiões próximas à superfície (distância $\mathrm{X}_{0}$ ) pode haver um aumento ou uma diminuição na concentração de íons enquanto que na solução essa concentração é sempre constante (Figura 2.2).

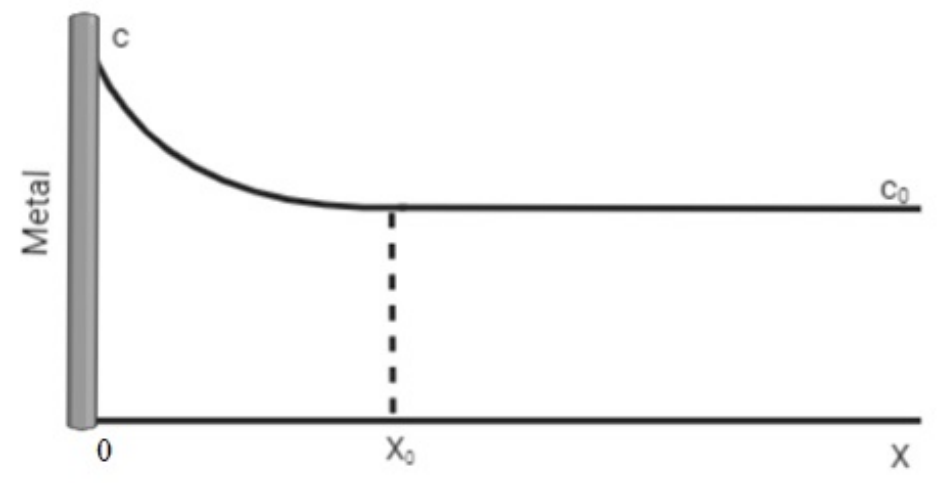

Figura 2.2: Perfil de concentração da adsorção acumulativa de espécies. Em $x=0$ corresponde à interface eletrodo/solução, a partir deste ponto as propriedades do eletrólito são constantes e correspondem às mesmas presentes no interior da solução. Fonte: adaptada de Ticianelli et al., 2013 [48]. 
No meio eletrolítico, as alterações na concentração de íons sempre envolvem espécies carregadas, o que resulta em uma distribuição desigual de cargas e consequentemente, uma diferença de potencial (d.d.p.) entre a superfície e o interior da solução. Uma das características desta d.d.p. no meio eletrolítico é o controle do potencial através de um circuito externo formado pela superfície e o meio, denominado dupla camada elétrica [48]. O acúmulo ou a carência de determinadas espécies na superfície interfacial com relação ao meio da solução (denominada adsorção) é um resultado da atuação de forças anisotrópicas presentes.

O primeiro modelo para descrever a dupla camada elétrica foi proposto por Helmholtz em 1853, e mostrava que a superfície do eletrodo poderia ser vista como um capacitor de placas paralelas. Uma das placas era representada como um acúmulo de cargas na superfície do metal e a outra não possuía uma existência física concreta, mas correspondia a um alinhamento de íons de mesmo sinal no meio eletrolítico, localizado a uma distância d da superfície. Assim, a capacitância (C) era descrita pela Equação 2.1:

$$
\begin{gathered}
C=\frac{\varepsilon_{r} \varepsilon_{0}}{d} \\
\varepsilon_{r}=\frac{\varepsilon}{\varepsilon_{0}}
\end{gathered}
$$

onde $\varepsilon_{r}$ é a permissividade relativa, $\varepsilon$ é a permissividade absoluta do meio e $\varepsilon_{0}$ é a permissividade do vácuo. Ao se comparar com os resultados experimentais, encontraram-se as limitações do modelo teórico.

Posteriormente, na tentativa de superar as limitações, Gouy-Chapman propuseram um outro modelo em 1910, denominado modelo da camada difusa, onde os íons que formam a placa do capacitor do lado da solução mãe estão alinhados corretamente, formando uma camada volumétrica difusa. Esse problema foi explicado pelas interações eletrostáticas que, diminuíam ou aumentavam as concentrações dos íons na superfície do eletrodo quando comparadas com aqueles presentes no interior da solução. Entretanto, mesmo assim o modelo proposto não correspondia ao experimental. Somente em 1924, Stern propôs que o modelo de Gouy-Chapmam não considerava que a distribuição difusa íons se iniciasse na 
superfície do eletrodo. Como havia a presença do solvente no sistema, os íons somente poderiam se aproximar da superfície do eletrodo até certa distância [48].

Apesar da correção proposta por Stern gerar grandes avanços nos estudos eletroquímicos, o mesmo ainda não explicava fenômenos de adsorção iônica em todos os eletrólitos. Posteriormente, Grahame determinou a parte final que faltava ao modelo de Stern. Os processos de adsorção de íons podiam se aproximar da interface do eletrodo de duas formas:

- interação fraca: esses íons agrupam-se e formam placas a uma distância que corresponde ao diâmetro das moléculas de água ligadas à superfície somadas ao raio dos próprios íons e de suas moléculas de hidratação. (Figura 2.3a)

- interação forte: alguns íons com ânions fracamente hidratados podem interagir fortemente com a superfície eletródica, deslocando as moléculas de água e entrando em contato direto com o metal do eletrodo (denominado adsorção específica), formando uma placa mais interna a uma distância de aproximadamente o raio do próprio íon. (Figura 2.3b)

O modelo proposto inicialmente por Helmholtz e modificado posteriormente é então aceito, indicando que todo processo eletroquímico possui uma dupla camada elétrica com as placas presentes: na superfície do metal; na camada mais interna formada pelos íons adsorvidos especificamente (plano de Helmholtz interno - do inglês inner helholtz plane - IHP); e a última na camada mais externa formada pelos íons adsorvidos fracamente e presentes na solução (plano de Helmholtz externo - do inglês outer Helmholtz plane - OHP), conforme ilustrado na Figura 2.3c [47, 48].

\subsubsection{Célula eletroquímica}

A descrição do modelo de dupla camada elétrica se aplica, entre outras coisas, ao desenvolvimento de biossensores eletroquímicos, que consistem experimentalmente na montagem de um sistema composto por três eletrodos, conforme descrito na Figura 2.4 abaixo. Os eletrodos são posicionados conforme ilustrado e são classificados de acordo com sua função: o eletrodo de trabalho, terá sua superfície funcionalizada para o reconhecimento biológico; o eletrodo de referência, que possui um potencial conhecido e não-polarizável; e por último, um 
(a)

(b) região livre de moléculas

(c)

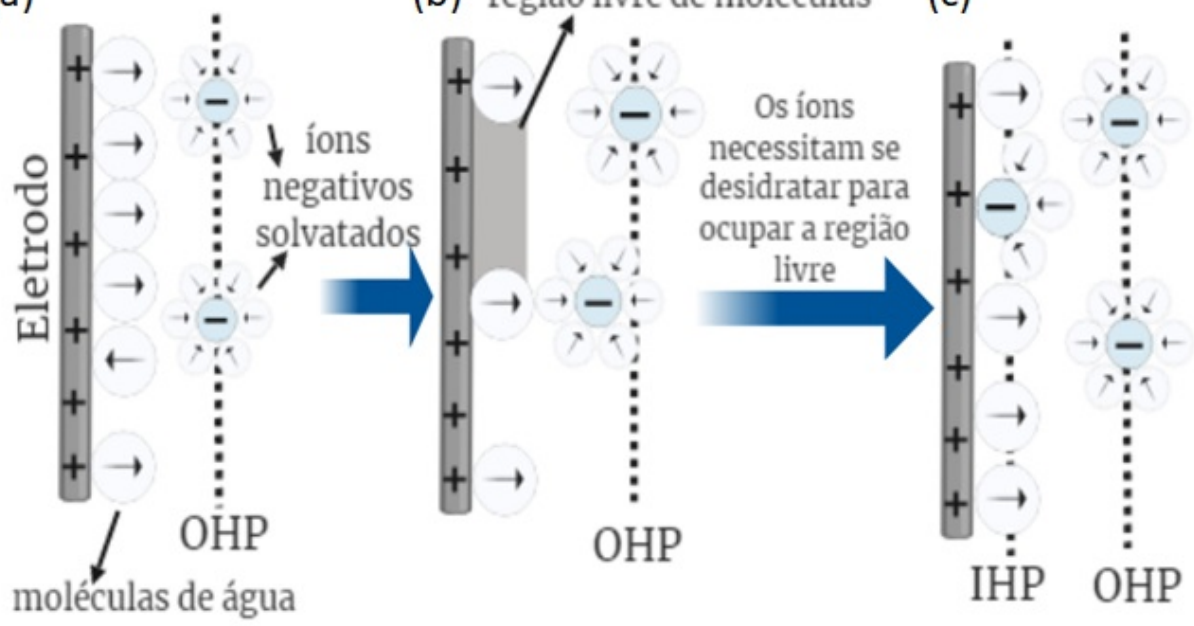

Figura 2.3: Processos de adsorção de espécies: a) interação inicialmente fraca; b) interação forte; c) formação da dupla camada. Fonte: adaptada de Ticianelli et al., 2013 [48].

contra eletrodo que auxilia na medição desejada. Essa conformação de 3 eletrodos constitui uma célula eletroquímica.

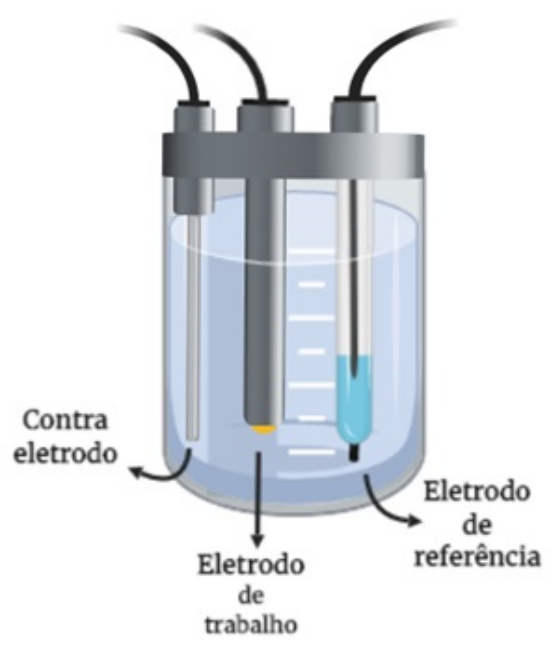

Figura 2.4: Ilustração de uma célula eletroquímica.

O uso da célula eletroquímica permite diferentes tipos de medidas:

- amperométrica: se baseia na medição da corrente resultante da oxidação eletroquímica ou redução da espécie eletroativa [49, 50]; 
- condutométrica: mede a condutância/resistência elétrica da solução, usado principalmente em reações que produzem íons ou elétrons [46];

- potenciométrica: quantifica o potencial de oxidação ou redução de uma reação eletroquímica. Para isso, um potencial constante é aplicado no eletrodo de referência com relação ao eletrodo de trabalho, formando um potencial de circuito aberto (OCP) [46].

Para o desenvolvimento deste projeto uma algumas técnicas serão utilizadas, entre elas destaca-se a espectroscopia de impedância eletroquímica, que será abordada em detalhes.

\subsubsection{Técnicas eletroquímicas de caracterização}

Conforme descrito na seção 2.1.1, a eletroquímica é a parte da química que estuda os efeitos das mudanças químicas causadas pela passagem da eletricidade. O campo da eletroquímica aborda diferentes áreas de acordo com os fenômenos envolvidos (eletroforese e corrosão), com os dispositivos (sensores eletroanalíticos, baterias, células de combustível) e com as tecnologias (galvanização de metais e produções em larga escala de alumínio e cloro por exemplo). Dentre essas áreas apresentadas, o atual trabalho apresentará três grandes técnicas responsáveis por compreender os processos acerca da interface e da superfície do eletrodo: a espectroscopia de impedância eletroquímica (EIE); a espectroscopia de capacitância eletroquímica (ECE); a voltametria cíclica (VC) [51].

\subsubsection{Espectroscopia de Impedância Eletroquímica}

O estudo de processos microscópicos sempre necessita ser da forma mais cuidadosa possível para que todas as observações possam ser realizadas sem a influência de outros processos causados por algum efeito cascata gerado no sistema. Para isso, o uso de baixos potenciais de varredura, ou baixos passos de potenciais/corrente são empregados para os estudos da interface, pois essas mudanças normalmente causam uma pequena perturbação que retira o eletrodo de seu equilíbrio para assim, observar os acontecimentos desde a perturbação ao seu retorno ao seu estado estacionário. Dentre as vantagens dessas análises estão: 
medidas obtidas com alta precisão; respostas mais lineares e simples dos processos e medidas que podem ser realizadas em função do tempo (ou frequência) [51].

(a)

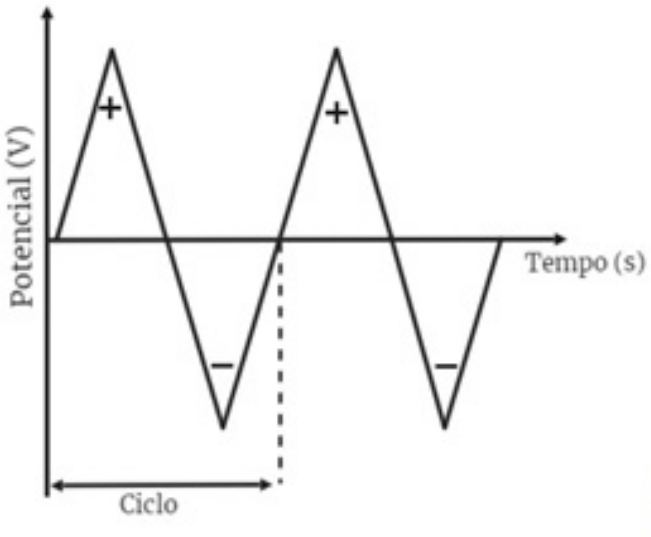

(b)

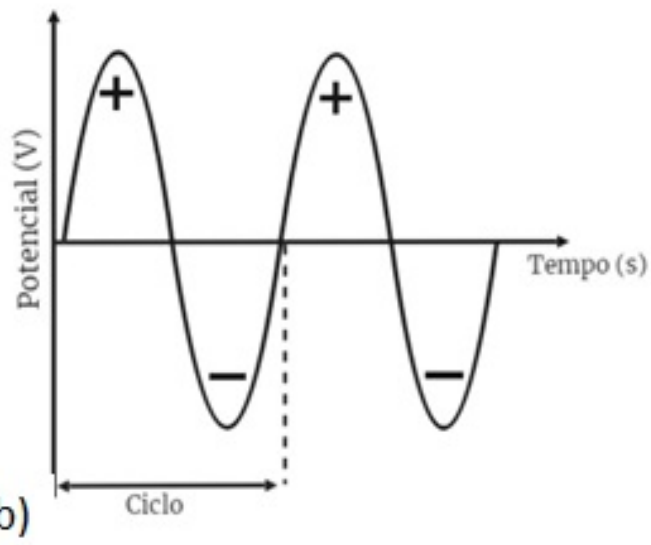

Figura 2.5: Tipos de ondas periódicas: a) triangular; b) senoidal. Fonte: adaptada de Bard et al., 1980 [51].

A aplicação da EIE tem como base a utilização de potenciais alternados (AC) que geram perfis de forma periódica (Figura 2.5). Dentre esses perfis gerados, a forma senoidal é a mais utilizada devido a sua facilidade matemática. O potencial DC normalmente aplicado nesse sistema é dado como um potencial de circuito aberto (OCP), onde não há a presença de corrente. Com o OCP fixo em relação a um eletrodo de referência, aplica-se um potencial (V) de forma senoidal (equação 2.3):

$$
V(t)=V_{m} \operatorname{sen}(\omega t+\theta)
$$

onde $\mathrm{V}(\mathrm{t})$ é o potencial instantâneo para cada instante de tempo t (s); $\mathrm{V}_{m}$ é o pico de amplitude da onda senoidal do potencial aplicado; $\theta$ é a ângulo de fase; $\omega$ é a frequência angular ( $\mathrm{rad} / \mathrm{s})$. Ao se aplicar esse potencial senoidal, gera-se uma a corrente senoidal, como mostra a expressão 2.4:

$$
I(t)=I_{m} \operatorname{sen}(\omega t+\phi)
$$

Sendo I(t) é a corrente instantânea gerada em um instante de tempo t (s); $\mathrm{I}_{m}$ é a amplitude máxima da onda senoidal e $\phi$ é o angulo de fase. A aplicação deste potencial e a consequente geração de corrente abre a possibilidade do estudo da 
resistência do circuito formado pela aplicação da Lei de Ohm conforme a expressão 2.5:

$$
I(t)=\frac{V(t)}{R}=I_{R} \operatorname{sen}(\omega t+\phi)=\frac{V_{R} \operatorname{sen}(\omega t+\theta)}{R}
$$

onde $\mathrm{I}_{r}$ e $\mathrm{V}_{r}$ representam a corrente e o potencial do resistor respectivamente. Nessa expressão 2.5 é possível notar que as fases (e consequentemente a frequência $\left.\mathrm{f}_{r}, \omega=2 \pi \mathrm{f}_{r}\right) \theta$ e $\phi$ são iguais. Em sistemas AC senoidais num circuito puramente capacitivo, teremos:

$$
I_{c}(t)=\frac{d Q}{d t}=C \frac{d V_{c}(t)}{d t}
$$

onde $\mathrm{I}_{c}$ e $\mathrm{V}_{c}$ representam a corrente e o potencial do capacitor respectivamente. Se adicionarmos a expressão 2.1 na 2.5, é possível encontrar uma mudança de fase na corrente de $90^{\circ}$ :

$$
\begin{gathered}
I_{c}(t)=I_{m} \operatorname{sen}\left(\omega t+90^{\circ}\right) \\
I_{m}=\omega C V_{m}
\end{gathered}
$$

sendo C é a capacitância do sistema.

Tendo em mente tais processos torna mais simples a compreensão da impedância $(Z)$ do sistema, pois a mesma adota componentes reais (Z') e imaginários (-Z') tanto na forma retangular:

$$
Z=Z^{\prime}-i . Z^{\prime \prime}
$$

Ou na forma polar:

$$
Z=|Z| e^{i \phi}=\left(\sqrt{\left(\left(Z^{\prime}\right)^{2}+\left(Z^{\prime \prime}\right)^{2}\right)}\right)(\cos (\phi)+i \cdot \operatorname{sen}(\phi))
$$

onde $\mathrm{i}=\sqrt{(-1)}, \phi$ é o ângulo entre Z' e Z" conforme a equação $2.11 \mathrm{e}$ ilustrado na Figura 2.6

$$
\phi=\tan ^{-1} \frac{Z^{\prime \prime}}{Z^{\prime}}
$$




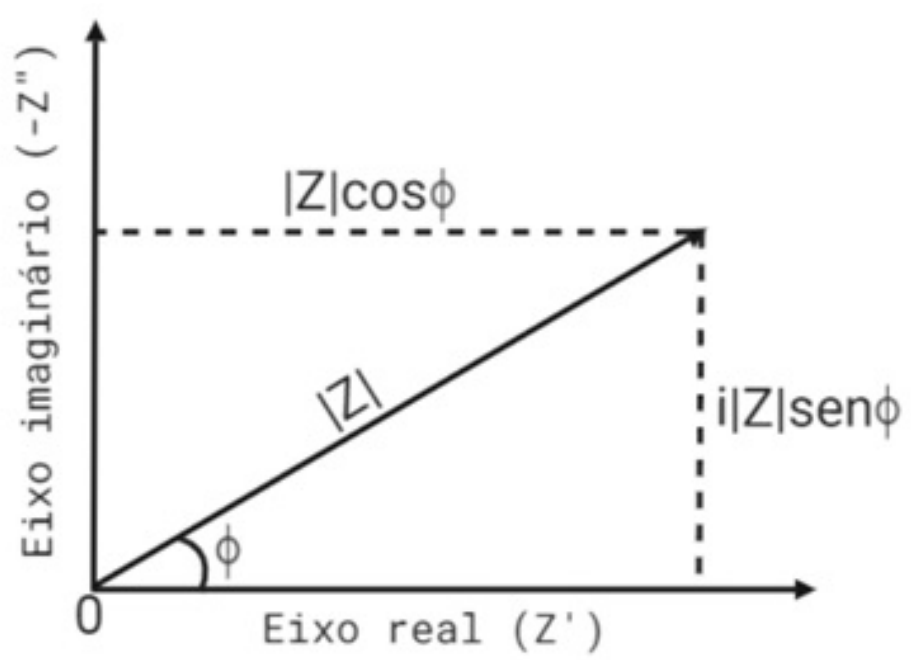

Figura 2.6: Representação ilustrativa da impedância real (Z') e imaginária (Z”). Fonte: adaptada de Bard et al., 1980 [51].

A impedância em circuitos a.c. representa uma certa resistência à passagem de corrente, possuindo uma representação matemática com base na Lei de Ohm:

$$
Z=\frac{V(t)}{I(t)}
$$

Essa impedância possui uma parte relacionada ao resistor $\left(Z_{r}\right)$ e uma relacionada ao capacitor $\left(\mathrm{Z}_{C}\right)$ :

$$
\begin{gathered}
Z_{R}=R \\
Z_{C}=\frac{V_{m} \operatorname{sen}(\omega t+\theta)}{I_{m} \operatorname{sen}(\omega t+\phi)}
\end{gathered}
$$

$\operatorname{como}(\omega+\theta)=0^{\circ}$ e $(\omega+\phi)=90^{\circ}$,

$$
Z_{C}=\frac{V_{m} e^{i 0^{o}}}{I_{m} e^{i 90^{\circ}}}=\frac{V_{m} e^{i 0^{o}}}{\omega C V_{m} e^{i 90^{\circ}}}=\frac{e^{i\left(-90^{\circ}\right)}}{\omega C}
$$

Onde pela fórmula de Euler:

$$
\begin{gathered}
e^{i\left(-90^{\circ}\right)}=\cos \left(-90^{\circ}\right)+i \operatorname{sen}\left(-90^{\circ}\right) \\
Z_{c}=\frac{-i}{\omega C}=\frac{1}{i \omega C}
\end{gathered}
$$


Considerando as expressões 2.13 e 2.17 é possível realizar a montagem de dois tipos de circuitos equivalentes:

I - Série

Nesse sistema, a impedância total $\left(\mathrm{Z}_{T R C}\right)$ é considerada como a soma das impedâncias individuais de cada componente. Para um circuito RC em série tem-se a expressão 2.20 representada pela Figura 2.7a e a linha contínua preta representa o ajuste pelo circuito equivalente presente na Figura 2.7b:

$$
Z_{T R C}=R+\frac{1}{i \omega C}
$$

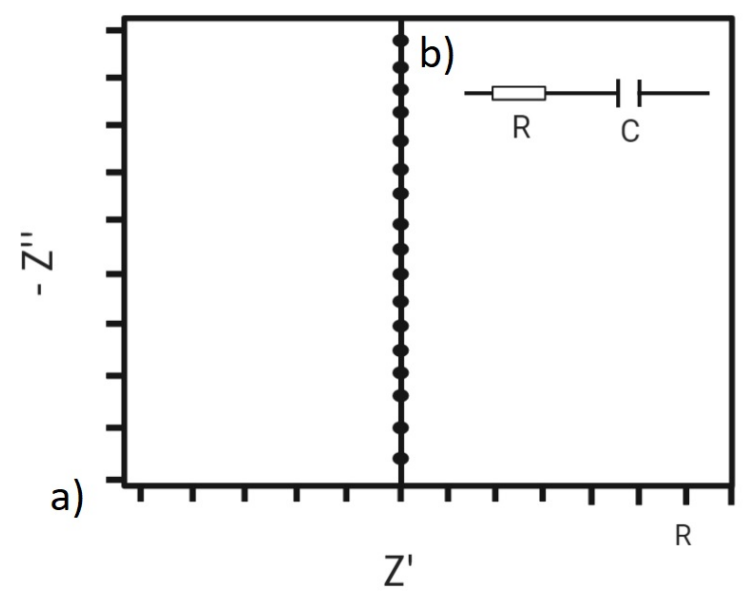

Figura 2.7: a) Representação gráfica da impedância de um circuito $R C$ em série conforme mostra a equação 2.24; b) circuito equivalente utilizado para a modelagem dos dados. Fonte: adaptada de Bard et al., 1980 [51].

II - Paralelo

O sistema em paralelo tem como a impedância total $\left(\mathrm{Z}_{T R C}\right)$ a soma do inverso das componentes individuais. Para um circuito RC tem-se:

$$
\frac{1}{Z_{T R C}}=\left(\frac{1}{Z_{R}}+\frac{1}{Z_{C}}\right)=\left(\frac{1}{R}+i \omega C\right)^{-1}
$$


Reunindo as duas componentes da expressão 2.24 e reescrevendo na forma complexa:

$$
Z_{T R C}=\frac{R}{1+(\omega R C)^{2}}-i \frac{\omega R^{2} C}{1+(\omega R C)^{2}}
$$

onde:

$$
Z^{\prime}=\frac{R}{1+(\omega R C)^{2}}
$$

$\mathrm{e}$

$$
Z^{\prime \prime}=-\frac{\omega R^{2} C}{1+(\omega R C)^{2}}
$$

Sendo a fase dada por:

$$
\tan \phi=-\omega R C
$$

A expressão 2.20 permite compreender algumas particularidades do circuito: em baixas frequências $\left(\omega \mathrm{RC} \ll 1, \mathrm{Z}^{\prime} \approx \mathrm{R}\right.$ e $\mathrm{Z}^{\prime \prime} \approx 0$ ) o circuito atua como um resistor; para altas frequências $\left(\omega R C \gg 1, Z^{\prime} \approx 0\right.$ e $\left.Z^{\prime \prime} \approx \frac{1}{\omega C}\right)$ o circuito atua como um capacitor.

A simplificação da equação 2.20 é dada pela expressão 2.24 e sua representação gráfica é mostrada na Figura 2.8:

$$
\left(Z^{\prime}-\frac{R}{2}\right)^{2}+\left(Z^{\prime \prime}\right)^{2}=\left(\frac{R}{2}\right)^{2}
$$

A Figura 2.8a indica que para $\omega \rightarrow 0$ o gráfico cruza o eixo real no ponto $(\mathrm{R}, 0)$ e, para $\omega \rightarrow \propto$ o gráfico cruza a origem $(0,0)$, formando assim um semicírculo com raio $\mathrm{R} / 2$ e centrado no ponto $(\mathrm{R} / 2,0)$. O espectro da EIE é representado como a impedância do sistema $\left(Z_{r e, i}, Z_{i m, i}\right)$ em função da variação de frequência ( $\omega \mathrm{i}$, com $\mathrm{i}=1,2, \ldots \mathrm{n})$ e recebe o nome de diagrama de Nyquist. Os resultados apresentados pelo Nyquist são comumente analisados pelo ajuste de um circuito elétrico equivalente, sendo composto por resistores, capacitores, indutores e alguns elementos já descritos na área eletroquímica como elementos de Warburg (W) [52] e de fase constante (CPE) [53]. Para modelar os dados presentes na figura 2.8a, o 


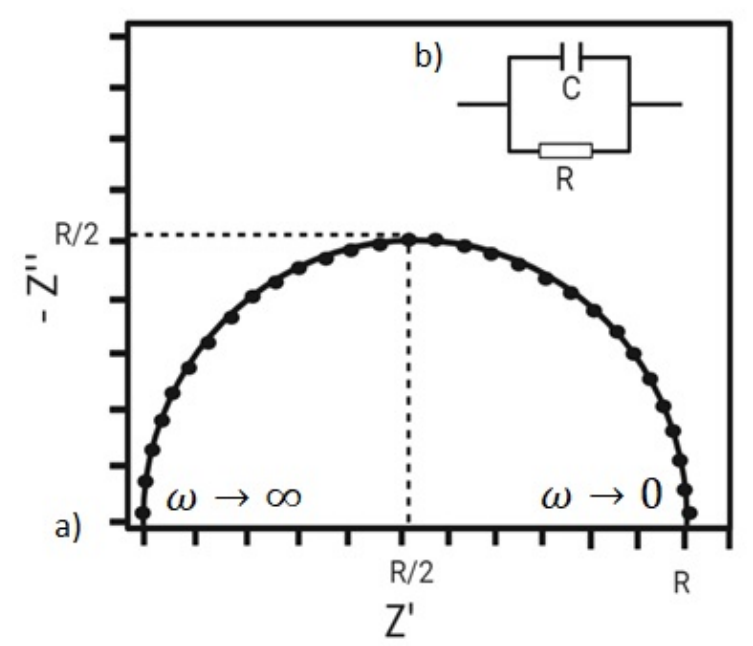

Figura 2.8: a) Representação gráfica da impedância de um circuito $R C$ em paralelo conforme mostra a equação 2.24; b) circuito equivalente utilizado para a modelagem dos dados. Fonte: adaptada de Bard et al., 1980 [51].

circuito $\mathrm{RC}$ equivalente utilizado está representado em detalhe na figura $2.8 \mathrm{~b}$, e seu ajuste está demonstrado pela linha contínua preta.

O objetivo principal de um circuito equivalente é apresentar o melhor ajuste teórico com os dados experimentais utilizando a menor quantidade de elementos possível. O modelo mais simples e mais utilizado para EIE é descrito pelo circuito equivalente de Randles, composto por uma resistência da solução eletrolítica $\left(\mathrm{R}_{s}\right)$ em série com sistema paralelo de capacitância que representa a dupla camada elétrica $\left(\mathrm{C}_{d l}\right)$ e uma resistência à transferência de carga $\left(\mathrm{R}_{c t}\right)$ que representa toda a resistência do sistema ao processo de transferência de cargas da solução para o eletrodo. A Figura 2.9a representa os dados experimentais obtidos na célula eletroquímica. Para ajustar estes dados, utilizou-se o circuito elétrico equivalente representado na Figura $2.9 \mathrm{~b}$ no qual a $\mathrm{C}_{d l}$ (modelo ideal da superfície como um capacitor) é substituída pela CPE (modelo não-ideal), pois a mesma leva em consideração os efeitos de rugosidade da superfície do eletrodo de ouro [54]; o acréscimo do elemento $\mathrm{W}$ representa o sistema que sofre influência dos processos cinéticos e difusionais, alterando o processo de transferência de carga. O elemento de Warburg é reconhecido pela linha com aproximadamente $45^{\circ}$ na região de baixa frequência do gráfico presente na Figura 2.9a. O ajuste teórico obtido pelo circuito 
equivalente está representado pela linha contínua preta presente na Figura 2.9a.

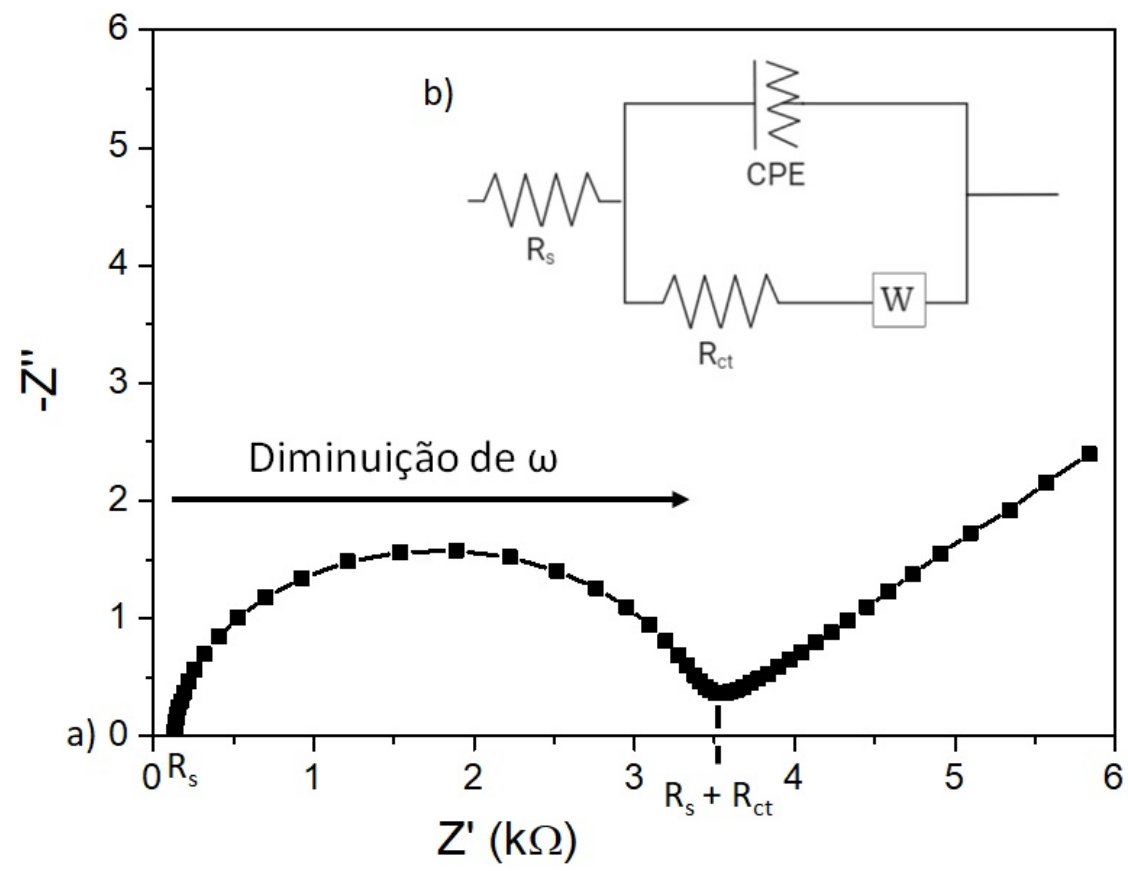

Figura 2.9: Ilustração do modelo referente à interface eletroquímica: a) circuito equivalente de Randles e b) diagrama de Nyquist com o ajuste do circuito equivalente. $R_{s}$ representa a resistência da solução; $R_{c t}$ representa a resistência à transferência de carga; CPE representa a capacitância da dupla camada elétrica e $W$ representa a impedância de warburg. Fonte: adaptada de Góes et al., 2012 [54].

O diagrama de Nyquist é representado por um semi-círculo: nas altas frequências $(\omega \rightarrow \propto)$ a impedância do CPE é baixa, sendo governado portanto pela $\mathrm{R}_{s}$; em baixas frequências $(\omega \rightarrow 0)$, o sistema é governado pela soma da $\mathrm{R}_{c t}$ com a $\mathrm{R}_{s}$; nas frequências intermediárias, o CPE é carregado até atingir o pico do semi-círculo, decaindo posteriormente devido ao domínio do $\mathrm{R}_{c t}+\mathrm{R}_{s}$. Por fim, para frequências muito baixas $(\omega \gg 0)$, o sistema é governado pelos processos difusionais de Warburg (W) [55]. A Figura 2.10a representa uma célula eletroquímica de três eletrodos com todos os processos eletroquímicos envolvidos (transferência de massa e carga) conforme já descrito anteriormente na seção 2.1.1. Além disto, Figura 2.10b ilustra a representação do circuito equivalente já descrito na Figura 2.9b. 


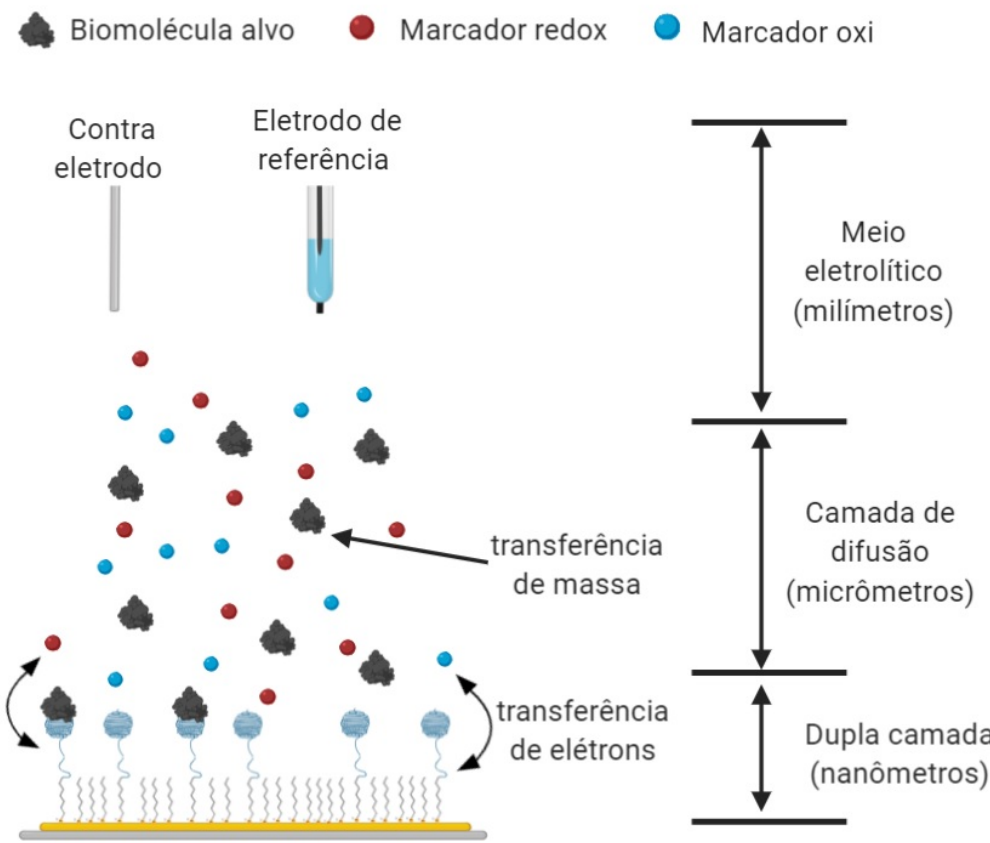

(a)

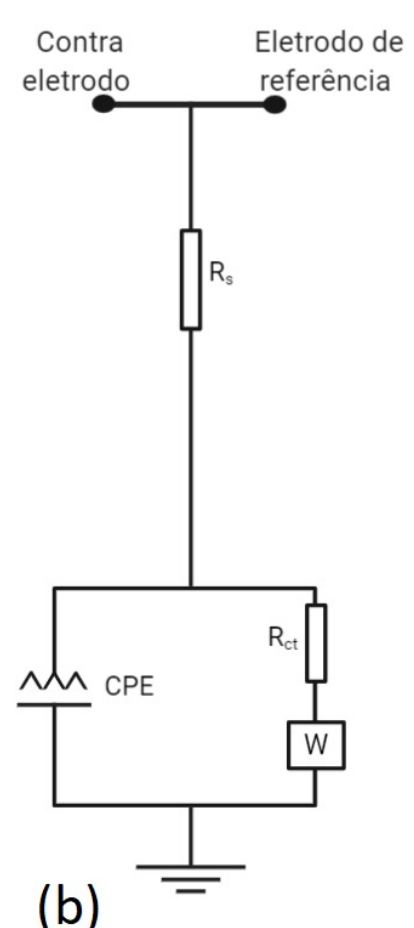

Figura 2.10: Ilustração a) Todos sistema eletroquímico em uma célula de três eletrodos e os processos envolvidos; b) circuito elétrico equivalente do sistema. Fonte: adaptada de Bard et al., 1980 [51].

\subsubsection{Espectroscopia de Capacitância Eletroquímica}

Conforme descrito na seção 2.1.1.1, a interpretação dos processos mais próximos à superfície do sensor era realizada pelo mesmo efeito de um capacitor. O acúmulo de cargas entre a interface sólido/líquido pode ser modelado como um capacitor de placas paralelas:

$$
\begin{gathered}
C=\frac{\varepsilon_{r} \varepsilon_{0} A}{d} \\
\varepsilon_{r}=\frac{\varepsilon}{\varepsilon_{0}}
\end{gathered}
$$

Onde C é a capacitância; d é distância entre as placas; $\varepsilon_{r}$ e $\varepsilon$ são as permissividades relativas e absolutas do meio, respectivamente; $\varepsilon_{0}$ é a permissividade vácuo; A é a área do eletrodo. O modelo de Gouy-Chapman-Stern (GCS) propõe que a capacitância da dupla camada elétrica é dada pela soma das capacitâncias 
individuais:

$$
\frac{1}{C_{d l}}=\frac{1}{C_{H}}=\frac{1}{C_{d}}
$$

onde $\mathrm{C}_{H}$ é a capacitância de Helmholtz e $\mathrm{C}_{d}$ é a capacitância dessa interface onde ocorre os processos de difusão [54]. Como descrito na seção 2.1.1.2, todo procedimento eletroquímico tem como base a montagem da célula eletroquímica e como forma de condução, usa-se uma solução eletrolítica que permite a condução dos íons da solução para a interface sólida. A presença da solução hidratada modifica a capacitância anteriormente formada, surgindo um novo termo $\left(\mathrm{C}_{m}\right)$ :

$$
\frac{1}{C_{m}}=\frac{1}{C_{s}}=\frac{1}{C_{d l}}
$$

onde $\mathrm{C}_{s}$ é a capacitância da solução eletrolítica. A capacitância da equação 2.28 pode ser interpretada como um capacitor de placas paralelas. Caso $\mathrm{C}_{d l}>\mathrm{C}_{s}$, tem-se que o sistema é dominado pela interface sólido/líquido, ocasionando um valor de $\mathrm{C}_{m}$ próximo de $\mathrm{C}_{s}$, fenômeno presente nos processos de difusão. Para o estudo desses processos interfaciais, o uso da espectroscopia de capacitância eletroquímica (ECE) se faz necessário.

Para a interpretação de modificações próximas a superfície, a ECE conta com o uso de sondas "confinadas", ou seja, funcionalizações no eletrodo de trabalho utilizando moléculas como 6-(ferrocenil)hexanotiol (FCC) que possuem um átomo de ferro (Fe) que pode ser fixada a superfície e utilizada para aquisição do sinal (Figura 2.11).

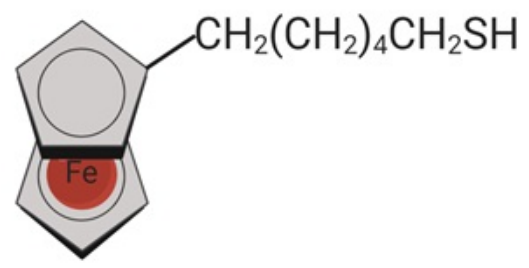

Figura 2.11: Ilustração do 6-(ferrocenil)hexanotiol com o átomo de ferro (Fe) confinado.

A imobilização desta molécula na superfície do eletrodo permite o estudo do sinal interfacial gerado pelo acúmulo dessas cargas [56] e dependendo exclusivamente do meio eletrostático. Por essas cargas estarem mais próximas da superfície, a ECE 
permite análises das mudanças conformacionais de forma mais precisas [57] que a EIE, sendo utilizada portanto para o estudo das interações entre solução e interface.

Os dados gerados pela ECE são derivados matematicamente dos sinais de $Z^{*}(\omega)$ da EIE, originando um termo de capacitância complexa $C^{*}(\omega)$ em função da variação de frequência:

$$
\begin{gathered}
Z *(\omega)=\frac{1}{i \omega C^{*}(\omega)} \\
C^{\prime \prime}=\frac{Z^{\prime}}{\omega\left|Z^{*}\right|^{2}} \\
C^{\prime}=-\frac{Z^{\prime \prime}}{\omega\left|Z^{*}\right|^{2}}
\end{gathered}
$$

onde C' é capacitância real; C" é a capacitância imaginária [56]. A ECE tem como resultado gráficos similares aos obtidos pela EIE. A Figura 2.12 ilustra os diagramas impedânciométricos e os capacitivos obtidos pela equação 2.30 e 2.31. Em sistemas sem a presenças das cargas confinadas (Figura 2.12a e 2.12b) observa-se os processos difusionais já descritos na seção 2.1.2.1 pelo diagrama de Nyquist, não havendo o acúmulo de cargas na superfície. A adição das cargas confinadas (Figura $2.12 \mathrm{c}$ e d) tem como consequência o acúmulo das mesmas na superfície, formando um espectro capacitivo, diferente do modelo resistivo anterior.

\subsubsection{Voltametria cíclica}

A caracterização de filmes com sondas redox "confinadas"à superfície traz a possibilidade do estudo das interações analito-alvo de forma mais acurada. Dentre as técnicas eletroquímicas, o uso da voltametria cíclica permite encontrar um determinado potencial onde ocorre o máximo de transferência eletrônica, denominado de potencial de meia onda $\left(\mathrm{E}_{1 / 2}\right)$ [58].

A VC é responsável pelo fornecimento de informações quantitativas sobre os processos eletroquímicos, como a termodinâmica (reações em uma superfície) e cinética (velocidade de varredura do sistema) [59]. As respostas são obtidas pela varredura linear de um potencial inicial $\left(\mathrm{E}_{i}\right)$ até um potencial final $\left(\mathrm{E}_{f}\right)$ aplicado 

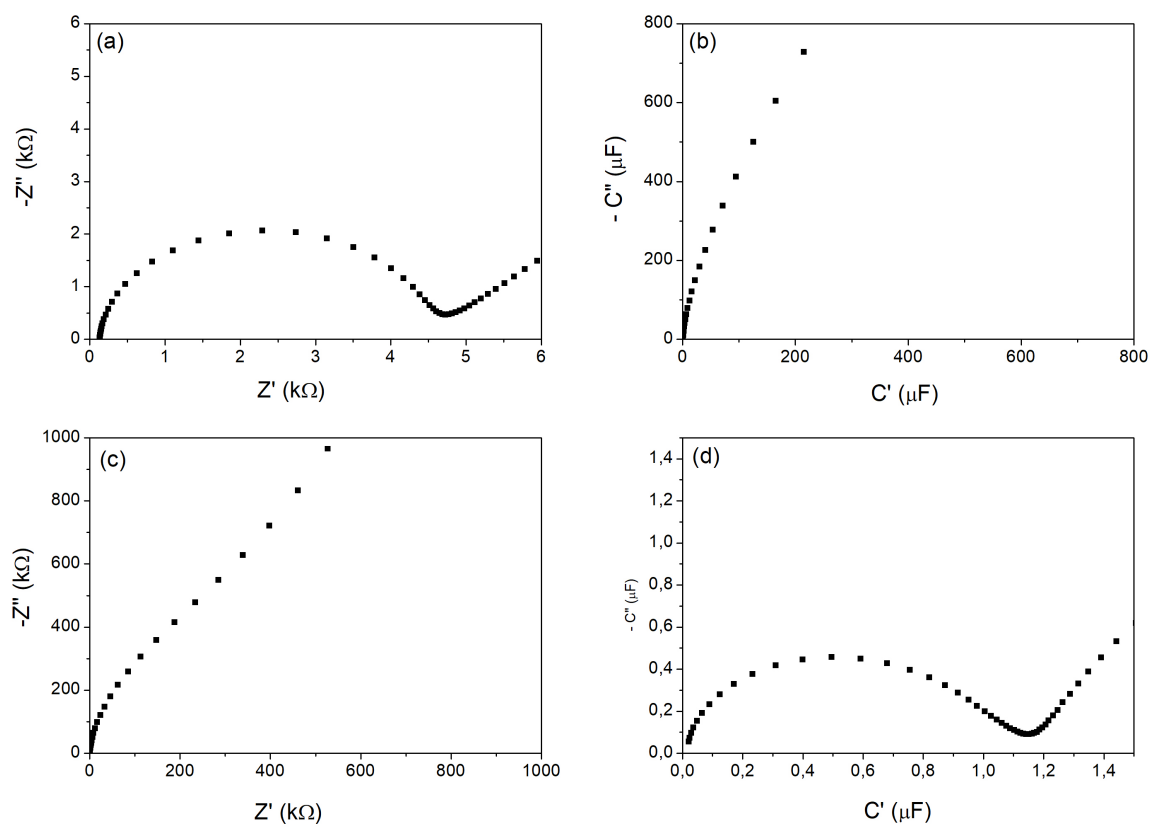

Figura 2.12: Diagramas obtidos para as plataformas: impedânciométrica $(a, c)$ sem e com cargas confinadas respectivamente; Capacitiva $(b, d)$ na ausência e na presença de cargas confinadas respectivamente.

no eletrodo de trabalho, sendo esse processo revertido de $\mathrm{E}_{f}$ até $\mathrm{E}_{i}$ novamente, formando um ciclo (Figura 2.13).

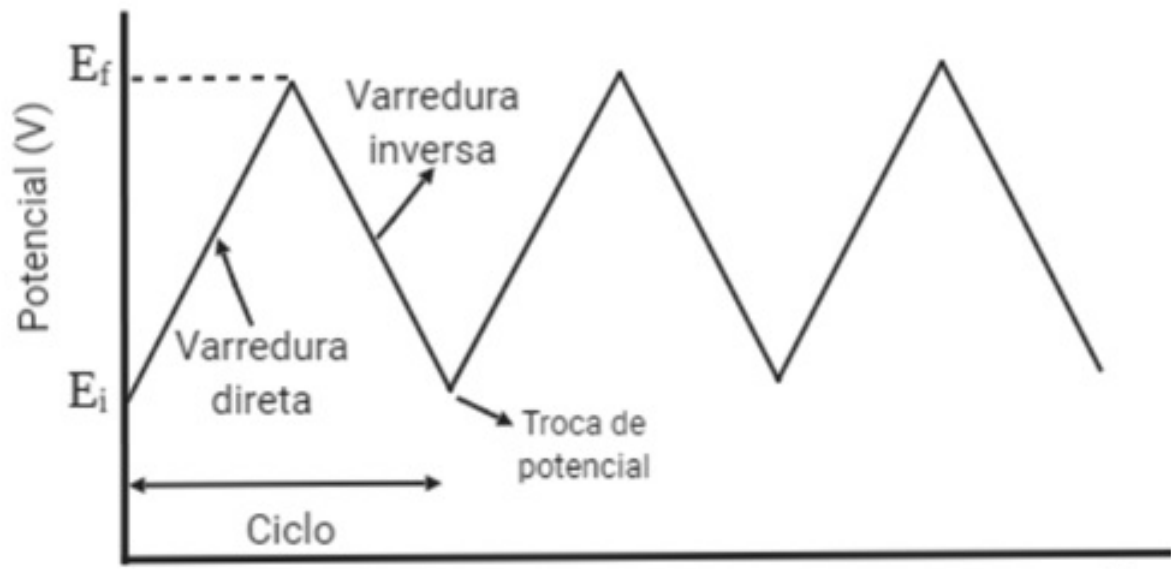

Tempo

Figura 2.13: Ilustração do sinal de potencial pelo tempo presente na voltametria cíclica. Fonte: adaptado de Yuan et al., 2010 [55]. 
Ao variar o potencial aplicado é possível obter uma resposta em função da corrente, gerando picos de oxidação na ida e, na volta os picos de redução. Assumindo que inicialmente o eletrodo possua apenas espécies oxidadas na sua superfície, à medida que o potencial aplicado se aproxima de $\mathrm{E}_{i}$ (potencial negativo), uma forma de redução do eletrodo se inicia, surgindo uma corrente de redução até atingir um pico (negativo) e depois começa a diminuir, resultante da formação de uma camada espessa próxima da superfície. Esse processo é denominado de processo não-faradaico, ou seja, não há transferência de carga.

Quando o potencial é invertido, todas a espécies que foram formadas pela corrente de redução sofrem oxidação, retornando para o pico de oxidação novamente. As inversões do potencial geram os processos faradaicos, ou seja, ocorre transferência de carga na superfície do eletrodo. Os picos de redução e oxidação representam a transferência de massa na superfície do eletrodo e apresentam um potencial $\left(\mathrm{E}_{r e d}\right.$, $\left.\mathrm{E}_{\text {oxi }}\right)$ e uma corrente referente aos processos $\left(\mathrm{I}_{\text {red }}, \mathrm{I}_{\text {oxi }}\right)$. A resposta de corrente versus potencial é visualmente chamado de voltamograma cíclico conforme demonstrado na Figura 2.14.

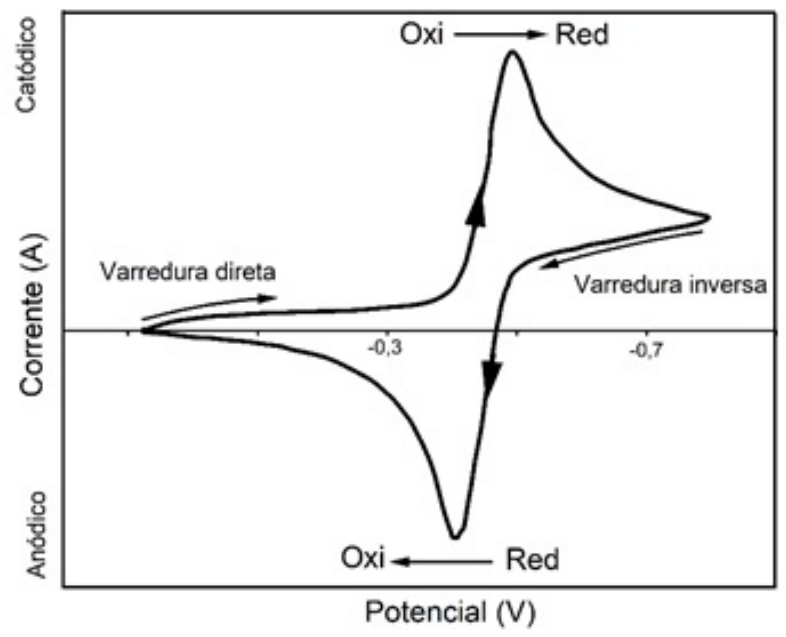

Figura 2.14: Representação gráfica de um voltamograma (corrente vs potencial) de um processo reversivel redox na voltametria cíclica. Fonte: adaptado de Yuan et al., 2010 [55].

Todo o processo eletroquímico é reversível em solução descrito acima possui as seguintes características: 
- o pico de corrente é proporcional a $\mathrm{v}$ e $\mathrm{I}_{\text {red }} / \mathrm{I}_{\text {oxi }}=1$, onde $\mathrm{v}$ representa a velocidade de varredura de cada potencial aplicado.

- a posição dos picos não mudam com a quantidade de varreduras realizadas.

- a separação entre os picos de redução e oxidação é dada pela equação 2.32:

$$
\Delta E=E_{\text {oxi }}-E_{\text {red }}=2,3 \frac{R_{\text {gas }} T}{n F}=\frac{0,059}{n} \nu
$$

Onde $\mathrm{R}_{g s}$ é a constante do gás ideal; $\mathrm{T}$ é a temperatura (aprox. $25^{\circ} \mathrm{C}$ ); $\mathrm{F}$ é a constante de Faraday; n é o número de elétrons transferidos pelo processo de difusão [55]. Para as reações reversíveis, é possível obter o potencial de máxima transferência eletrônica $\left(\mathrm{E}_{\text {in }}\right)$ :

$$
\Delta E_{\text {in }}=\frac{E_{\text {oxi }}+E_{\text {red }}}{2}
$$

Para as reações irreversíveis, o valor de um dos picos não aparecerá, possuindo apenas uma variação da corrente $\left(\mathrm{I}_{\text {red }}\right.$ ou $\left.\mathrm{I}_{o x i}\right)$ e consequentemente, um potencial de pico $\left(\mathrm{E}_{r e d}, \mathrm{E}_{\text {oxi }}\right)$.

\subsubsection{Microscopia de Força Atômica}

A microscopia de força atômica (AFM) surgiu em 1986 na combinação dos princípios de STM e perfilômetro (instrumento usado para medir a rugosidade das superfícies). De maneira geral, o princípio de funcionamento do AFM é obter as imagens de superfície pela deflexão do cantilever, atraindo ou repelindo a ponta de prova ao entrar em contato com a amostra [60]. A Figura 2.15 ilustra a montagem do sistema.

O funcionamento da AFM ocorre com a presença de um espelho no cantilever que reflete um feixe laser, passando por uma lente e incidindo em um fotodetector que por sua vez, mede as variações de posição e intensidade da luz produzida pelas deflexões. Conforme a varredura ocorre (com o movimento da ponta ou da amostra), o detector registra as "irregularidades geográficas"geradas pela interação da ponta com a superfície. Com esses dados, um computador processa as informações topográficas em imagens bi e tridimensionais [61]. 


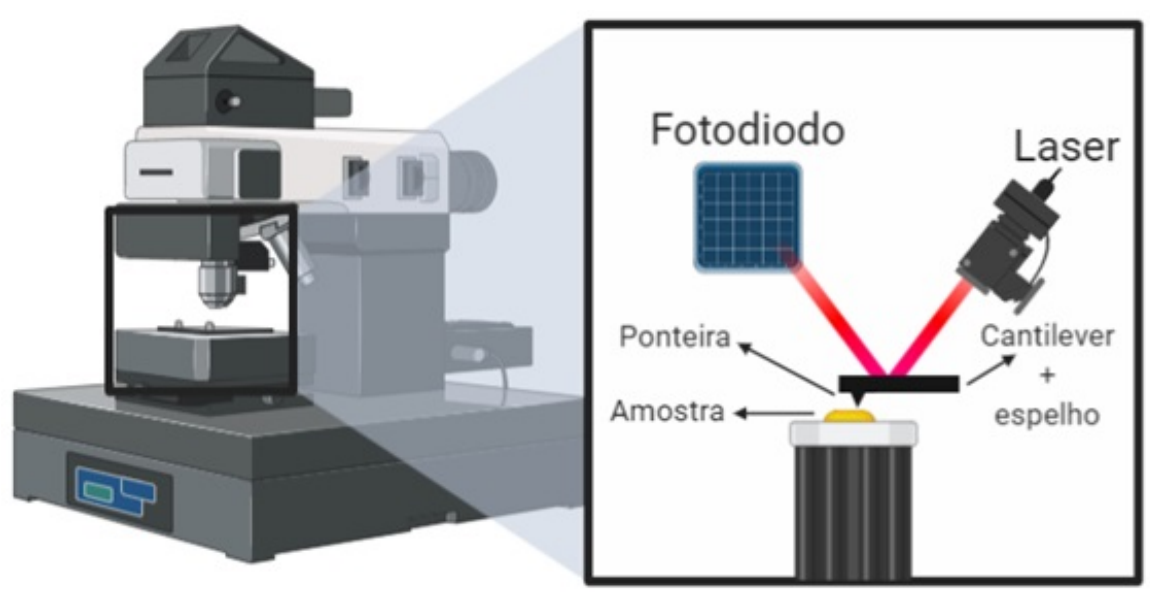

Figura 2.15: Representação esquemática do funcionamento do microscópio de força atômica. Fonte: adaptado de Ferreira et al., 2006 [61].

O sistema AFM é capaz de trabalhar em três modos que dependem da distância de interação da ponteira com a superfície: Modo de contato (menor distância possível); Modo de não-contato (maior distância da superfície); Modo de contato intermitente (entre os dois anteriores) conforme ilustra a Figura 2.16.

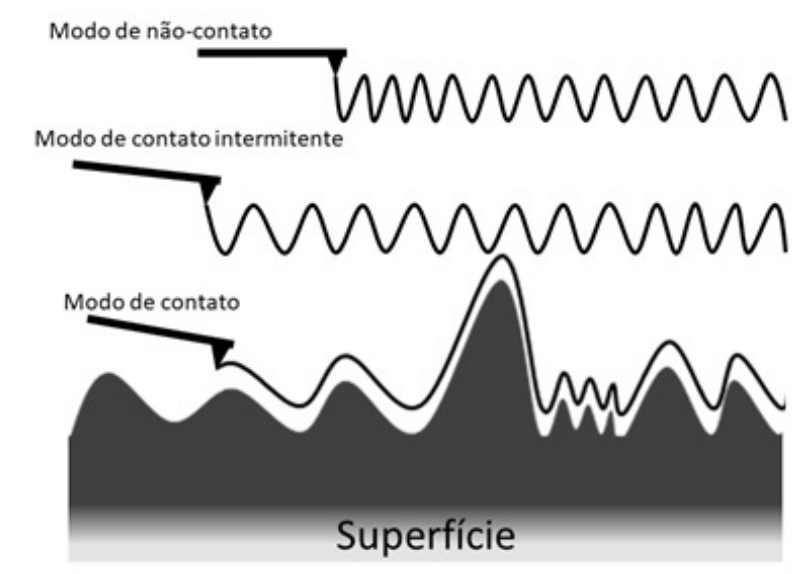

Figura 2.16: Ilustração dos três modos de funcionamento da AFM: contato (linha superior); não contato (linha inferior); intermintente (linha intermediária). Fonte: adaptado de Oliveira et al., 2012 [62].

Dos três modos, o modo intermitente é o mais utilizado para o estudo de interações na superfície, pois permite que o cantílever ressoe em uma frequência, "batendo"levemente na superfície e interagindo com as forças presentes próximas a ela [62]. Desta interação é possível extrair informações de parâmetros de altura que 
representam a rugosidade de superfície [62]:

- Rugosidade aritmética $\left(\mathrm{R}_{a}\right)$ é um parâmetro obtido pela média aritmética da amplitude dos picos presentes na superfície, sendo o parâmtro mais simples de se obter.

- Rugosidade máxima $\left(\mathrm{R}_{y}\right)$ é obtido pela altura máxima encontrada a partir de uma linha base.

- Profundidade máxima $\left(\mathrm{R}_{v}\right)$ é obtido pela medida do vale mais profundo a partir de da linha base.

- Rugosidade total $\left(\mathrm{R}_{t}\right)$ é obtido pela distância entre o vale mais profundo e a maior altura.

- Rugosidade quadrática média $\left(\mathrm{R}_{q}\right)$ é uma função que analisa o quadrado das medidas, sendo mais sensível aos picos e vales que o parâmetro $\mathrm{R}_{a}$.

Através destes coeficientes é possível observar a topografia de uma superfície e dos biomateriais / biomoléculas adsorvidas na mesma.

\subsection{Aptâmeros}

Diversos tipos de receptores biológicos vêm sendo utilizados para biossensoriamento, entre os amplamente utilizados estão as enzimas e anticorpos. Entretanto, a evolução da tecnologia permitiu o desenvolvimento de biomoléculas artificiais funcionais utilizando processos in vitro. Estes processos permitiram que dois grupos em 1990 conseguissem isolar sequências de RNA capazes de se ligar a uma molécula alvo específico $[63,51,52]$. Esse tipo de sequência funcional recebeu o nome de Aptâmero (do latim - aptus, cujo significado é ajustar) [64]. Após essa descoberta, essa classe ganhou atenção da comunidade científica, sendo encontrados aptâmeros de DNA capazes de se ligar fortemente a uma grande quantidade de alvos (Ex: proteínas, peptídeos, aminoácidos, drogas, íons metálicos e até mesmo células inteiras)[65].

Os aptâmeros são criados através de ciclos seletivos de ligação seguido de amplificação usando a técnica SELEX (evolução sistemática de ligante por 
enriquecimento exponencial) [66]. Por causa de sua capacidade de se dobrar ("folding") após a ligação a sua molécula alvo, vários tipos de dispositivos começaram a ser estudados e montados, se tornando uma importante ferramenta para diagnóstico e terapia. A criação de biossensores fundamentados em aptâmeros (aptassensores) apresentou uma grande vantagem em comparação aos inúmeros biossensores baseados em enzimas e anticorpos, entre elas a seleção in vitro para qualquer alvo; são quimicamente estáveis; e possuem uma alta flexibilidade por sua capacidade de se dobrar na sua ligação com o alvo, lhe conferindo alta sensibilidade e seletividade da detecção [64].

O primeiro aptassensor foi criado por Kleinjung et. al. [36, 55] para testar detecção da L-adenosina e consequentemente permitia determinar as constantes de cinética equilíbrio do sistema, contribuindo principalmente para o ramo de identificação de drogas. Estudos posteriores visaram analisar mais profundamente as características dos aptâmeros, sendo explorados em diferentes metodologias, como eletroquímica, óptica e piezoelétrica $[64,67]$. Como resultado, os aptâmeros são capazes de adotar diferentes configurações para efetuar a transdução dos eventos de reconhecimento biológico (Figura 2.17).

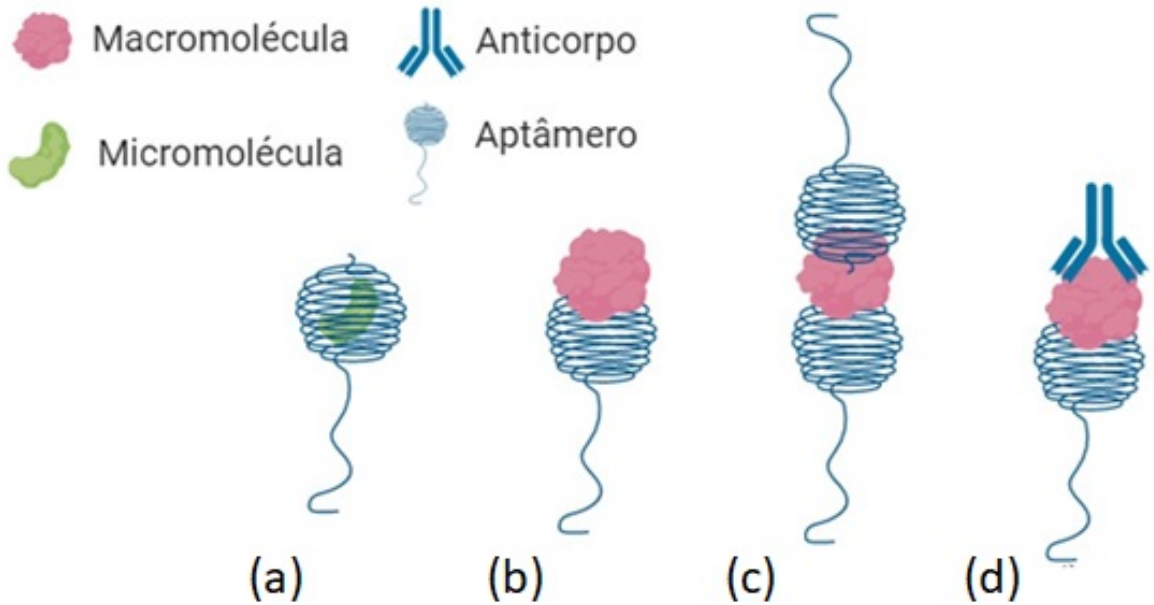

Figura 2.17: Configuraçôes de aptâmeros: a) ligação simples com micromolécula; b) ligação simples com macromoléculas; c) ligação dupla ou sanduíche com macromolécula; d) sanduíche com um aptâmero e um anticorpo. Fonte: adaptada de Song et al., 2008 [64].

O tipo de alvo influencia na sua conformação, sendo que os pequenos alvos 
são frequentemente envoltos pela bolsa de ligação do aptâmero (Figura 2.17a), não havendo espaço para uma interação com uma segunda molécula (sítio único). As proteínas maiores podem apresentar tanto sítio de ligação simples (Figura 2.17b) quantos sítios de ligação duplos (Figura 2.17c) devido às suas estruturas complicadas, permitindo assim vários pontos de ligação (que podem ocorrer por interações eletrostáticas, ligação de hidrogênio, etc.). A ligação de sítio duplo permite que o dispositivo montado possua um formato de sanduíche, com um aptâmero responsável pela captura do alvo, e o outro responsável pela sinalização (fósforos, enzimas ou nanopartículas (NPs)). Por fim, em casos onde não há o aptâmero de sinalização, é possível usar um anticorpo como a outra metade do sanduíche (Figura 2.17d) [64].

Ao se utilizar os aptâmeros com os métodos de medidas eletroquímicos como previamente citado, alguns pesquisadores como Jolly et al. passaram a desenvolver dispositivos para detecção de doenças como câncer de próstata [68]. Ao buscar formas de biossensoriamento utilizando aptâmeros para doenças como a Dengue, não foi encontrado nenhum resultado na literatura até 2017. Porém, Lee et al. conseguiram desenvolver em 2017 um aptâmero capaz de se ligar à proteína não estrutural (NS1) da Zika e consequentemente da Dengue [69]. Tal resultado levantou a possibilidade do desenvolvimento de um aptassensor eletroquímico para detecção da proteína NS1 da Dengue, conforme será visto no decorrer deste trabalho. 


\section{Capítulo}

\section{FABRICAÇÃO, OTIMIZAÇÃO E CARACTERIZAÇÃo Do Biossensor}

Neste capítulo é apresentado como ocorre o processo de pré-tratamento do eletrodo, que consiste de etapas de polimento, dessorção e limpeza eletroquímica. Seguindo o processo de limpeza, serão abordadas formas distintas para o melhor "folding"e imobilização do aptâmero. Além disto, serão abordados tópicos sobre o uso da proteína de soro bovino (BSA) como bloqueio de superfície. Para o preparo da proteína NS1, serão testados os tipos de soluções de diluição; o pH dessa solução; o uso de BSA na mesma para uma eventual estabilização da amostra e por fim, será visto a escolha dos melhores parâmetros que estão envolvidos na técnica de espectroscopia de impedância eletroquímica, como o tipo de potencial aplicado e o eletrodo de referência..

\subsection{Fabricação}

\subsubsection{Monocamada auto-organizada com aptâmeros}

Um dos modelos mais estudados para a funcionalização de filmes finos compostos por moléculas orgânicas capazes de se organizar espontaneamente de forma sólida sobre uma superfície recebe o nome monocamada auto-organizada (do inglês self-assembled monolayer - SAM) [70]. Essa funcionalização com superfícies de ouro ocorre por meio de moléculas com alcanotióis que possuem uma grande afinidade pelas moléculas de ouro, formando uma ligação de quimissorção/covalente forte, espontânea e permitindo o surgimento de atrações eletrostáticas fracas entre as 
cadeias carbônicas presente nas laterais das cadeias aquil, atraindo e se organizando de forma quase simultaneamente, formando um filme intermolecular [71, 67], como ilustrado na Figura 3.1.

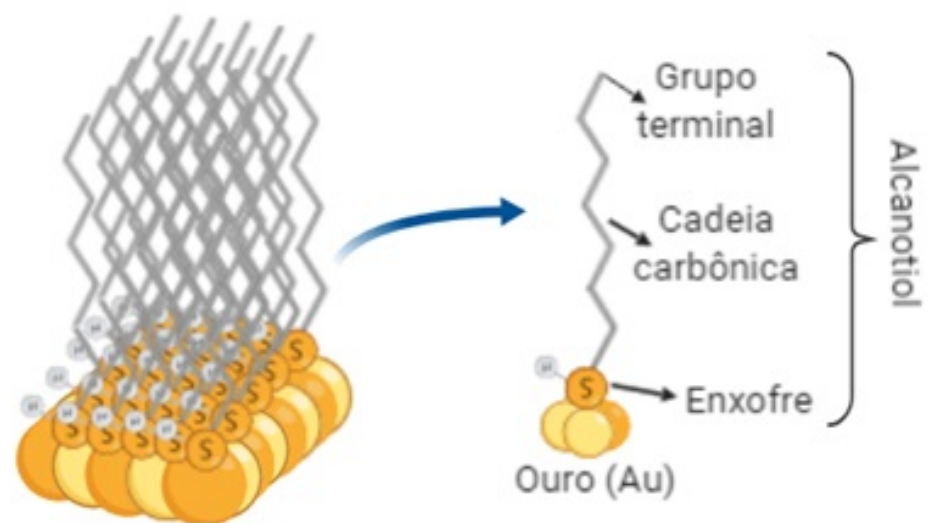

Figura 3.1: Ilustração da organização e estrutura dos alcanotióis na superfície do ouro. Fonte: adaptado de Thévenot et al., 2001 [50].

Os aptasensores presentes neste estudo são biossensores baseados em uma SAM composta de $1 \mu \mathrm{g} / \mathrm{mL}$ de 6 -mercapto-hexanol (MCH) e $1 \mu \mathrm{g} / \mathrm{mL}$ da sequência de aptâmero modificado com uma ligação tiol em solução, de forma que essa co-imobilização forme sítios de ligação simples com a superfície de ouro (Figura $3.2)$.

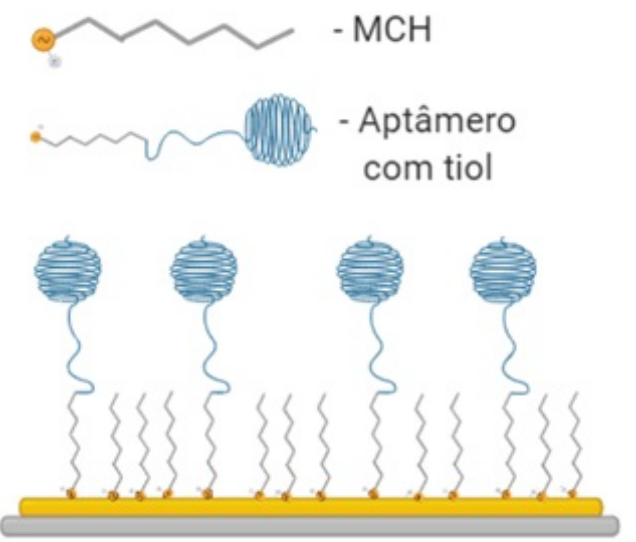

Figura 3.2: Ilustração da formação da superfície auto organizada composta por $M C H$ e aptâmero em um eletrodo de ouro.

O uso da co-imobilização entre aptâmeros de DNA e $\mathrm{MCH}$ tem como 
objetivo prevenir interações não específicas conforme demostrado por Keighleys et al. [52] em seu trabalho sobre imobilização de micro-DNA. A imobilização sequencial entre mDNA e MCH se mostrou insatisfatória na eliminação dessas interações não desejadas, sendo necessário, portanto o uso da imobilização simultânea das biomoléculas para solucionar esse problema. Keighleys propõe uma razão molar para essa formação da SAM, sendo descrita pela razão molar dos tióis na solução de imobilização (DNA/total tiol), onde o termo "DNA"representa a concentração de aptâmero e o "total tiol"a soma da concentração de todos os tióis presentes na superfície (aptâmero $+\mathrm{MCH}$ ).

A formação da SAM mista de aptâmeros e MCH e sua ligação com a proteína NS1 compõem a classe de biossensores denominados "label-free". Esses dispositivos visam simplificar os procedimentos operacionais, eliminando algumas etapas adicionais como a adição de marcadores para a detecção [72], comumente presentes em dispositivos categorizados como "label" [73].

\subsubsection{Materiais}

Para a fabricação das SAM todos os reagentes foram adquiridos da Sigma-Aldrich, bem como a sequência de aptâmeros. Todas as soluções foram preparadas com utilizando água ultrapura $(18,2 \mathrm{M} \Omega \mathrm{cm}$, Merck Milipore Direct-Q 5UV) com um filtro Biopak Polisher (Merck Milipore, CDUFB-001). A glicoproteína recombinante NS1 do sorotipo 4 da Dengue foi adquirida pela empresa Abcam (ab181957).

A sequencia de DNA do aptâmero utilizado é dada por 5' - $\mathrm{HS}\left(\mathrm{CH}_{2}\right)_{6}$ - TTTTT - ACTAGGTTGCAGGGGACTGCTCGGGATTGCGGATCAACCT AGTTGCTTCTCTCGTATGAT - 3' [59].

\subsubsection{Processo de limpeza do eletrodo}

Buscando minimizar os efeitos de rugosidade de superfícies, os eletrodos de ouro policristalinos foram pré-tratados com processos mecânicos e eletroquímicos. Conforme reportado por Carvalhal et al., esses tipos de procedimentos minimizam a rugosidade de superfície e permitem obter resultados mais reprodutíveis. Este métódo eletroquímico baseia-se ne medida da dessorção eletroquímica do oxigênio 
para o cálculo da área do eletrodo de ouro[74, 75]. Os eletrodos de ouro $2 \mathrm{~mm}$ de diâmetro adquiridos da Metrohm e da $\mathrm{CH}$ instruments foram submetidos aos seguintes processos de limpeza:

1. Primeiramente são dessorvidos eletroquimicamente em uma solução de $\mathrm{NaOH}$ $(0,5 \mathrm{M})$ com um potencial variando entre $-0,8$ a $-2 \mathrm{~V}$ (versus $\mathrm{Hg} / \mathrm{Hg}_{2} \mathrm{SO}_{4}$ ) em um total de 30 ciclos (Figura 3.3a) [52].

2. São polidos com aluminas de diferentes granulometrias $(1 \mu \mathrm{m}$ e $0,3 \mu \mathrm{m})$ intercalado com banho ultrassônico por 5 minutos [52].

3. São submetidos a uma limpeza eletroquímica em uma solução de $\mathrm{H}_{2} \mathrm{SO}_{4}$ $(0,5 \mathrm{M})$, com um potencial variando de $-0,5$ a $1,1 \mathrm{~V}$ (versus $\mathrm{Hg} / \mathrm{Hg}_{2} \mathrm{SO}_{4}$ ) em um total de 25 ciclos (Figura 3.3b)[52].

4. São lavados com água ultrapura Mili-Q e secos em gás nitrogênio $\mathrm{N}_{2}$.

O perfil obtido da limpeza eletroquímica foi utilizado para calcular o coeficiente de rugosidade $\left(\mathrm{f}_{r}\right)$ por meio da integração do pico de redução (Figura 3.3b em destacado) [66]. Esse valor é dividido pela taxa de redução por unidade de área microscópica do ouro $\left(390 \pm 10 \mu \mathrm{C} / \mathrm{cm}^{2}\right)$ [76] e o coeficiente resultante é obtido pela divisão da área real $\left(\mathrm{A}_{r}\right)$ do eletrodo pela área geométrica $\left(\mathrm{A}_{g}\right)$ como mostrado nas equações 3.1 e 3.2 abaixo:

$$
\begin{gathered}
A_{r}=\frac{A}{390} \\
f_{r}=\frac{A_{r}}{A_{g}}=\frac{A_{r}}{\pi r^{2}}
\end{gathered}
$$

Os valores do $\mathrm{f}_{r}$ são utilizados para normalização dos dados individuais de cada eletrodo. Os valores obtidos para esse coeficiente variaram entre 1,4 e 1,8 com uma SAM estável e reprodutível. Alguns estudos com alcanotióis longos (12 carbonos) mostram que os valores de coeficiente de área efetiva maiores que 1,6 podem interferir na reprodutibilidade e no bloqueio da SAM [70]. 

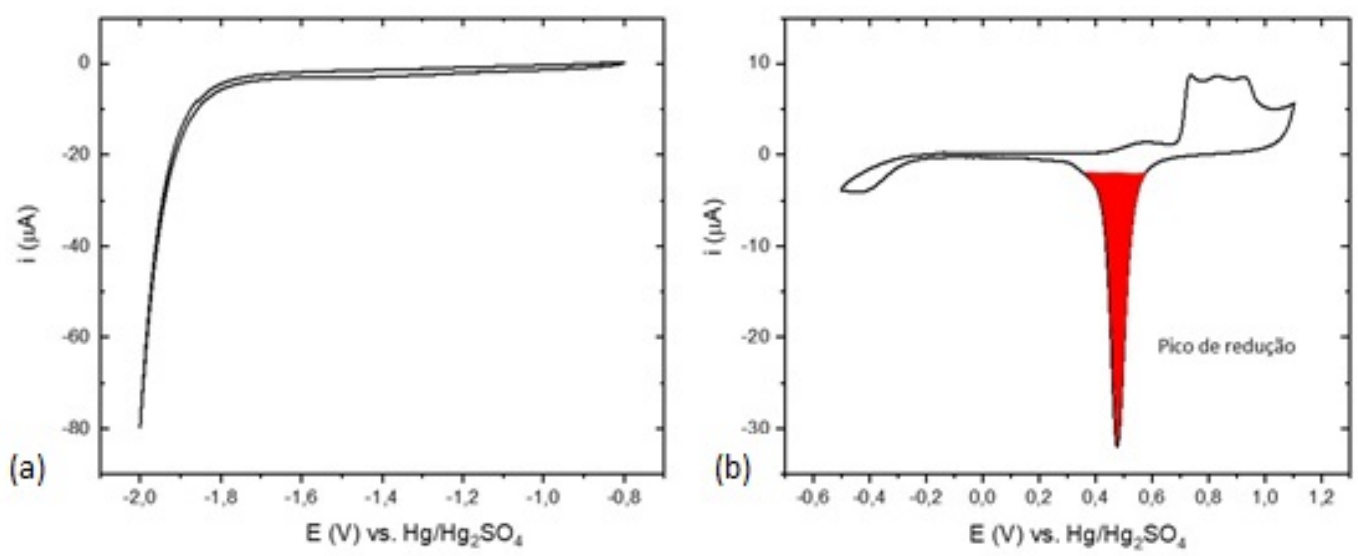

Figura 3.3: Curva obtidas dos processos de limpeza dos eletrodos de ouro: a) dessorção eletroquímica; b) limpeza eletroquímica. Ambos perfis cíclicos foram obtidos com uma velocidade de varredura de $100 \mathrm{~m} / \mathrm{s}$.

\subsubsection{Preparo do Aptâmero}

O aptâmero liofilizado é rehidratado com tampão TE (Tris + ácido etilenodiamino tetra-acético (EDTA), pH 8) com um volume específico para atingir a concentração estoque de $100 \mu \mathrm{g} / \mathrm{mL}$. Após esta hidratação, as soluções são divididas em pequenas alíquotas de $100 \mu \mathrm{L}$ e congeladas a $-40^{\circ} \mathrm{C}$ até seu uso.

A montagem da SAM ocorre após um tratamento térmico do aptâmero conforme mostra a Figura 3.4. As alíquotas são aquecidas à $95{ }^{\circ} \mathrm{C}$ por 10 minutos de forma a desnaturar as fitas de DNA, sendo posteriormente resfriadas à $4{ }^{\circ} \mathrm{C}$ por 15 minutos, favorecendo seu enovelamento. $\mathrm{O} \mathrm{MCH}$ é primeiramente diluído em etanol biológico puro (10 mM) e rediluído posteriormente em água mili-Q (10\%) para obter uma concentração de $1 \mathrm{mM}$. A solução de imobilização (Imob) do aptâmero consiste de $0,8 \mathrm{M}$ de tampão fosfato $(\mathrm{PB})+1 \mathrm{M} \mathrm{NaCl}+5 \mathrm{mM} \mathrm{MgCl}_{2}+1 \mathrm{mM}$ EDTA, pH 7 [52].

Após o tratamento térmico, o aptâmero é co-imobilizado com o MCH (1 mM, 10\% etanol) no tampão Imob em uma proporção 1:50 (aptâmero : Total tiol). Com os eletrodos previamente limpos, a solução com o aptâmero e o MCH é depositada na superfície do eletrodo de ouro, sendo posteriormente levado à geladeira por 16 a 18 horas à $4^{\circ} \mathrm{C}$ (Figura 3.4).

Após esta etapa, os eletrodos são mergulhados em 3 soluções de limpeza (1, 


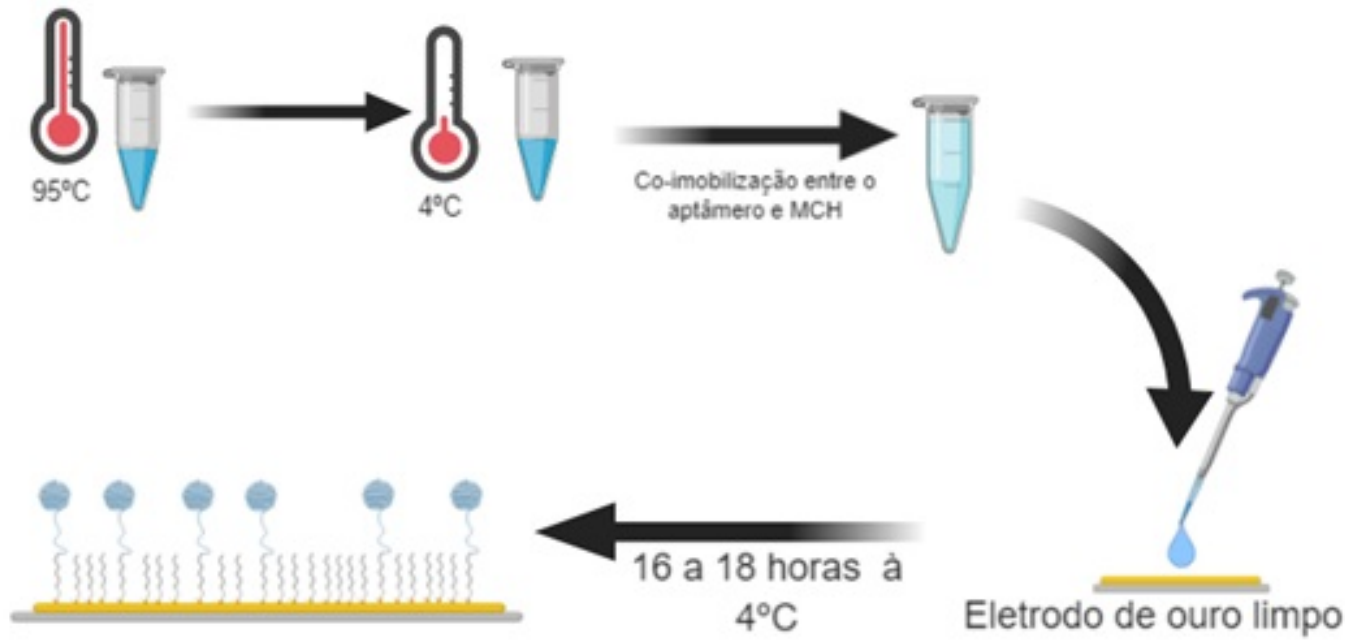

Figura 3.4: Processos de montagem da SAM. Tratamento térmico do aptâmero $\left(95^{\circ} \mathrm{C} e\right.$ em seguida $4^{\circ} \mathrm{C}$ ); Diluição do aptâmero e do $\mathrm{MCH}$ na solução de imobilização; Depósito da solução para a co-imobilização.

2, 3) por 5 minutos cada. As soluções de limpeza são compostas de 200 mM PB; $10 \mathrm{mM}$ PB + EDTA; e $10 \mathrm{mM}$ PB respectivamente. Posteriormente, os eletrodos são incubados com $100 \mu \mathrm{L}$ de solução de $\mathrm{MCH}$ (1 mM, 10\% etanol) por 1 hora para que toda a superfície do ouro seja preenchida, evitando assim as interações não específicas ("backfilling"). Por fim, os eletrodos são lavados em mili-Q e mergulhados novamente em solução de tampão fosfato salino - PBS $(137 \mathrm{mM} \mathrm{NaCl}+2,7 \mathrm{mM}$ $\left.\mathrm{KCl}+10 \mathrm{mM} \mathrm{Na} \mathrm{HPO}_{4}+1,8 \mathrm{mM} \mathrm{KH_{2 }} \mathrm{PO}_{4}\right)$ por 2 horas para a estabilização de sua superfície [52]. A Figura 3.5 mostra essas etapas de preparação do eletrodo.

\subsubsection{Instrumentação}

A montagem experimental consiste no uso de uma célula eletroquímica conforme já descrito (seção 2.1.1.2) composta de 3 eletrodos: o eletrodo de $\mathrm{Ag} / \mathrm{AgCl}$ (Metrohm) como de referência; o eletrodo de platina como o contra eletrodo (Metrohm) e o eletrodo de ouro (Metrohm ou CH instruments) como o de trabalho. As medidas eletroquímicas são obtidas com o uso do potenciostato Autolab PGSTAT20 (Metrohm) com Módulo FRA. Para a caracterização e otimização da SAM, utilizou-se a técnica de espectroscopia de impedância eletroquímica (EIE) onde um potencial de circuito aberto (OCP) sobreposto com uma amplitude de pico 


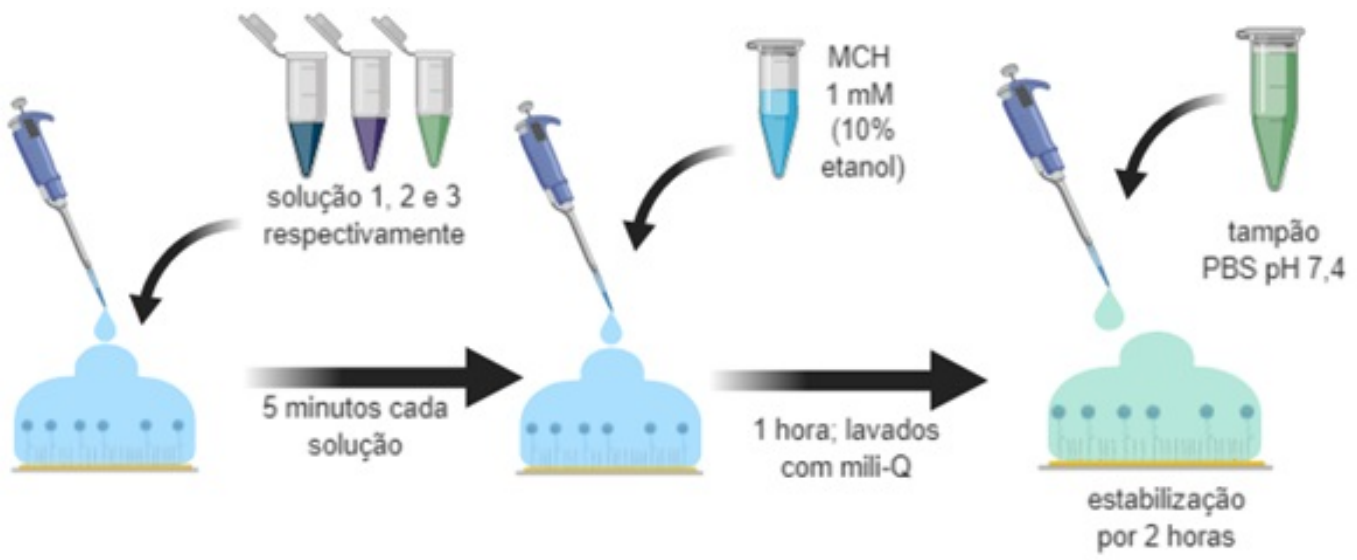

Figura 3.5: Etapas de limpeza após as 16-18 horas. Adição das soluções de limpeza 1, 2, e 3. Backfilling com MCH. Estabilização da SAM em tampão PBS para a subsequente realização das medidas.

de $10 \mathrm{mV}$ AC com a frequência variando de $100 \mathrm{mHz}$ a $100 \mathrm{kHz}$ foi aplicado em uma solução eletrolítica composta por tampão PBS pH 7,4 + 2,5 mM K 4 [ $\left.\mathrm{Fe}(\mathrm{CN})_{6}\right]+2,5$ $\mathrm{mM} \mathrm{K}_{3}\left[\mathrm{Fe}(\mathrm{CN})_{6}\right]$ Ferri/Ferro). A Figura B.1, no Apêndice B, ilustra o eletrodo de ouro, a montagem da célula eletroquímica e da plataforma de detecção.

\subsection{Otimização}

\subsubsection{Tampão de imobilização e preparação do aptâmero}

Um dos primeiros parâmetros a serem determinados e otimizados é o processo de tratamento térmico do aptâmero descrito na seção 3.1.4. O primeiro procedimento adotado foi o já descrito anteriormente, entretanto Kyung et al. fornece informações de que o aptâmero é submetido a um aquecimento por 10 minutos à $95^{\circ} \mathrm{C}$, sendo resfriado posteriormente em temperatura ambiente controlada $\left(23^{\circ} \mathrm{C}\right)$ por mais de 30 minutos [69]. Essas informações levantam a hipótese de que as mudanças nas condições de enovelamento poderiam alterar a conformação estrutural do aptâmero, impedindo a sua funcionalização por completo na SAM.

Da mesma forma, o atual estudo procurou determinar qual a melhor solução de imobilização, comparando a solução já previamente descrita (Imob) e amplamente utilizada pelo grupo com a solução SELEX $(20 \mathrm{mM}$ Tris pH 7,5 $+150 \mathrm{mM} \mathrm{NaCl}$ 
$\left.+1 \mathrm{mM} \mathrm{MgCl}_{2}+2,7 \mathrm{mM} \mathrm{KCl}+0,005 \% \mathrm{C}_{12} \mathrm{E}_{8}\right)[69]$.

Assim, para a montagem da SAM, o protocolo de preparo do aptâmero e a solução tampão foram otimizadas. Todos as SAMs foram montadas com uma proporção 1:150 (Aptâmero : Total Tiol), sendo realizado em seguida um bloqueio na superfície com BSA $(0,1 \%)$ por 30 minutos. Após o bloqueio, os eletrodos foram submetidos a diferentes concentrações de NS1 diluídas em tampão PBS pH 7,4 + BSA $(0,1 \%)$ por 30 min cada, partindo da menor concentração para a maior (10 $\mathrm{pg} / \mathrm{mL} ; 100 \mathrm{pg} / \mathrm{mL}$ e $1 \mathrm{ng} / \mathrm{mL})$. A justificativa para os valores aqui utilizados será apresentada nas próximas seções.

O resultado obtido é uma variação da resistência à transferência de carga $\left(\Delta \mathrm{R}_{c t}(\%)=\left(\mathrm{R}_{c t}(\right.\right.$ amostra $)-\mathrm{R}_{c t}($ branco $) / \mathrm{R}_{c t}($ branco $\left.\left.)\right) * 100\right)$ em função da concentração de NS1 conforme mostra a Figura 3.6.

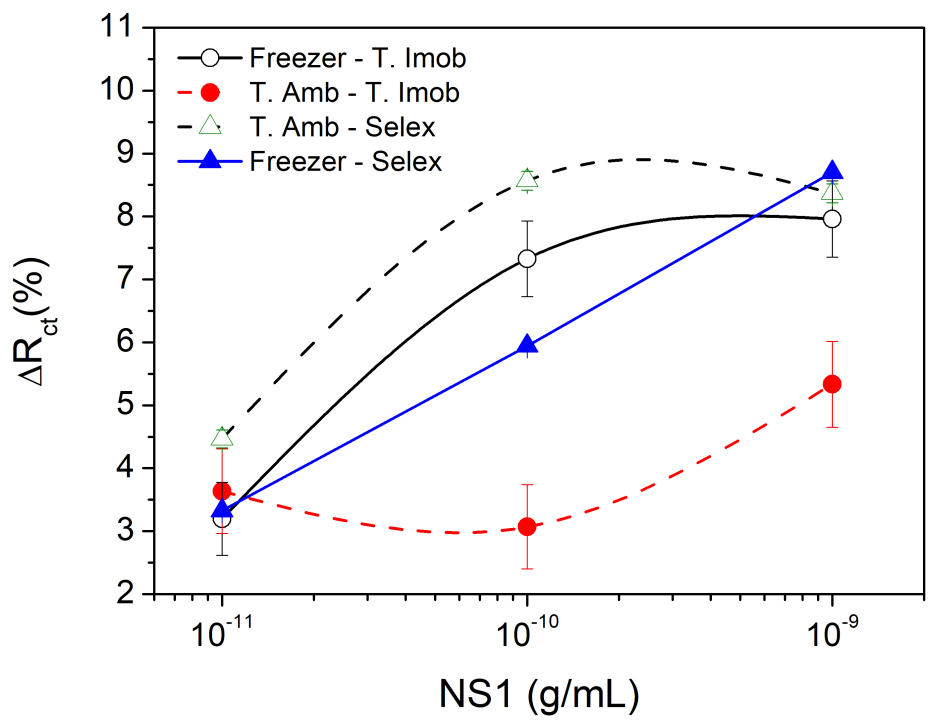

Figura 3.6: Variação da resistência à transferência de carga em função da concentração de NS1. O círculo (aberto e fechado) representa o uso do tampão Imob, variando a forma de refrigeração do aptâmero (freezer e temperatura ambiente respectivamente - T. Amb); Os triângulos (abertos e fechados) representam o uso do tampão SELEX, e a mesma variação da forma de enovelamento do aptâmero. As linhas (continuas e tracejadas) não representam um ajuste, mas são apenas uma forma de guia para o leitor.

Para cada concentração de NS1 é esperado um aumento do sinal de impedância, pois há uma quantidade maior de NS1 interagindo com o aptâmero na superfície da SAM. A partir da Figura 3.6 é possível observar que ao se fixar o 
tampão Imob (círculo aberto e fechado), o processo de enovelamento do aptâmero no freezer apresenta um sinal maior que o deixado à temperatura de $23{ }^{\circ} \mathrm{C}$. Porém, esse comportamento se mostrou oposto quando comparado à utilização do tampão SELEX (triângulos abertos e fechados), ou seja, o enovelamento à temperatura ambiente apresentou um aumento à transferência de carga significativamente maior.

Assim, o uso do tampão SELEX com os aptâmeros mantidos à temperatura ambiente demonstrou ser o procedimento mais favorável ao enovelamento da cadeia de oligonucleotídeo e consequentemente, a interação com a proteína alvo.

\subsubsection{Diluição do aptâmero após aquecimento}

Na seção anterior foi possível observar como o procedimento de preparo do aptâmero é capaz de alterar a resposta eletroquímica. Desta forma, levantou-se a hipótese de que a solução onde ocorre o resfriamento também possa afetar a interação com o alvo. Para elucidar tal dúvida os aptâmeros foram submetidos ao aquecimento por 10 minutos e sem seguida: imediatamente diluídos na solução de imobilização SELEX para resfriar por 40 minutos; deixado por 40 minutos em seu tampão de estoque (TE) para a posterior diluição no SELEX. Após esta etapa, as amostras seguiram o protocolo de montagem da SAM.

Ambas hipóteses seguiram proporção entre aptâmero e MCH (1 mM, 10\%) anterior com a superfície da SAM bloqueada com BSA (0,1\%). Após esta etapa, os eletrodos foram mergulhados em uma solução contendo NS1 diluído em tampão PBS + BSA (0,1\%) nas concentrações de $10 \mathrm{pg} / \mathrm{mL}, 100 \mathrm{pg} / \mathrm{mL}$, e $1 \mathrm{ng} / \mathrm{mL}$ por 30 minutos cada respectivamente. A Figura 3.7 mostra os resultados obtidos por meio da variação da resistência à transferência de carga $\left(\Delta \mathrm{R}_{c t}\right)$ em função da concentração de NS1.

Conforme demonstrado na Figura 3.7, a etapa de diluição do aptâmero representa uma grande importância para a formação da SAM e reconhecimento do alvo, onde é possível notar que a diluição prévia no tampão SELEX favorece a maximização do sinal em função da concentração de NS1 (círculo vermelho fechado), enquanto o sistema com a pós diluição (quadrado preto aberto) apresentou uma saturação. Essa resposta se deve principalmente à uma baixa concentração de aptâmeros novelados, visto que seu "folding"não foi favorecido. 


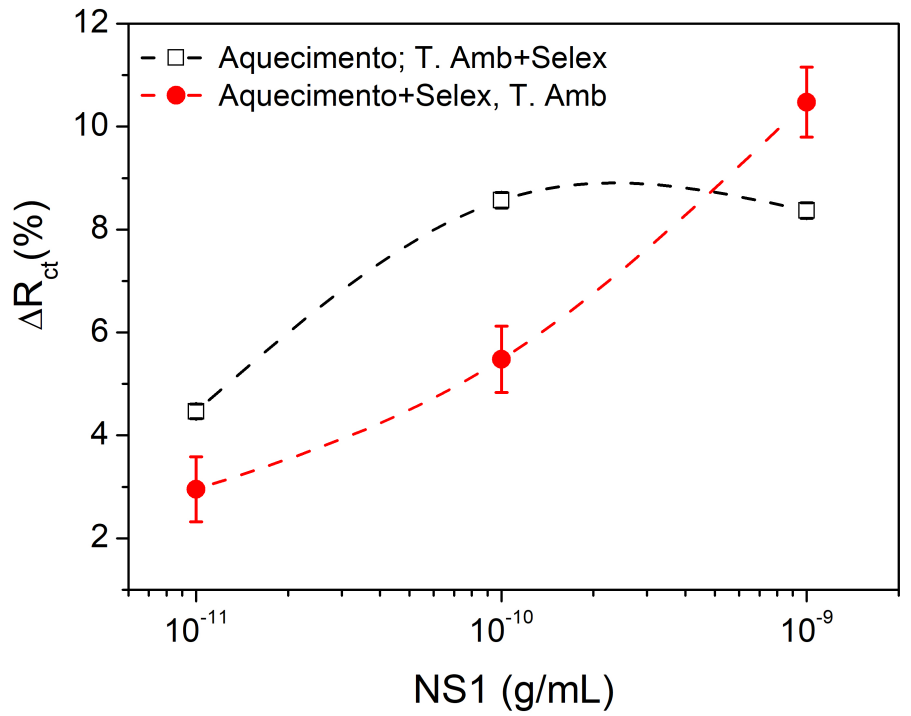

Figura 3.7: Variação da resistência à transferência de carga em função da concentração de NS1 para os dois métodos propostos. O quadrado aberto representa o aquecimento do aptâmero por 10 minutos seguido pelo resfriamento por 40 minutos e pela diluição no tampão SELEX. O círculo fechado representa o mesmo aquecimento, porém já diluindo no tampão SELEX e aguardando os 40 minutos para estabilizar. As linhas tracejadas não representam o ajuste, sendo apenas um guia.

\subsubsection{Preparo da proteína NS1}

O preparo inicial da NS1 seguiu os protocolos enviados pela Abcam, que consistia na diluição da amostra em $235 \mu$ de tampão $20 \mathrm{mM}$ Tris $+150 \mathrm{mM} \mathrm{NaCl}$, pH 8,5 para obter uma concentração estoque de $100 \mu \mathrm{l}$. Essas foram separadas em alíquotas de $10 \mu \mathrm{l}$ e congeladas no freezer a - $40{ }^{\circ} \mathrm{C}$ até o uso. Após as otimizações necessárias envolvendo a formação da SAM e o preparo do aptâmero, procurou-se estudar e caracterizar as melhores condições de desempenho da plataforma: o pH do tampão a ser utilizado para a diluição da proteína da concentração estoque (100 $\mu \mathrm{g} / \mathrm{mL})$ para a experimental $(1 \mu \mathrm{g} / \mathrm{mL})$; o tipo de tampão (PBS ou binding buffer BB) e a importância do uso da proteína de soro bovino (BSA) na solução de diluição da NS1. As otimizações desses três parâmetros serão apresentadas a seguir.

\subsubsection{1 pH do tampão PBS}

O estudo do pH do tampão na qual a proteína é diluída apresenta um aspecto de extrema importância, pois conforme descrito por O’Brien et al., a presença ou a 
ausência de íons podem afetar os estados termodinâmicos da proteína [77], alterando sua estabilidade protéica [78, 79]. Para determinar a influência do pH, selecionou-se o tampão PBS e alterou-se seu valor para 6,8, 7,5 e 8,5. A Figura 3.8 mostra os resultados do $\Delta \mathrm{R}_{c t}(\%)$ em função do $\mathrm{pH}$ do $\mathrm{PBS}$ para as duas concentrações de NS1 $(1 \mu \mathrm{g} / \mathrm{mL}$ e $100 \mathrm{ng} / \mathrm{mL})$.

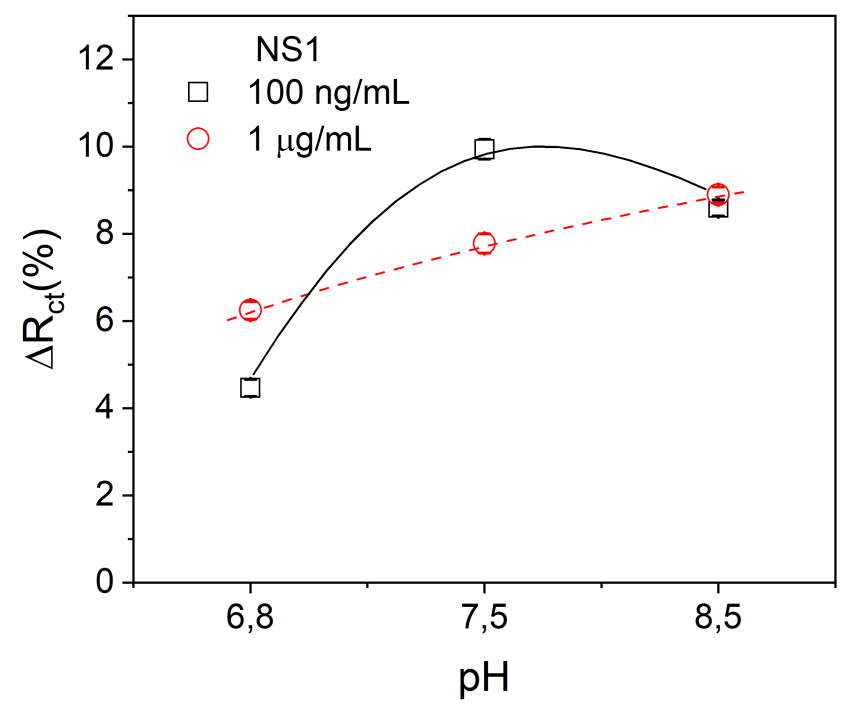

Figura 3.8: Variação de transferência à carga em função do valor de $p H$ do tampão PBS. As linhas abertas representam a $\Delta R_{c t}(\%)$ para a $N S 1$ à $1 \mu \mathrm{g} / \mathrm{mL}$ e os quadrados abertos representam a mesma variação para a NS1 à $100 \mathrm{ng} / \mathrm{mL}$. As linhas tracejadas e continuas são apenas um guia, não representado qualquer modelo matemático.

A Figura 3.8 indica que a NS1 mantém sua resposta eletroquímica para os valores de pH iguais ou próximos do Sangue $(7,5)$, representado pelo máximo de sinal ao longo da linha contínua preta. Esse pico de sinal segue as observações feitas por Chura-Chambi et al., na qual os testes com cromatografia mostraram que a proteína NS1 mantém sua naturação em pH abaixos de 8,5 [80]. Essas análises permitem considerar o uso do tampão PBS em pH 7,5 para os próximos experimentos.

\subsubsection{Tipos de Tampão}

Além do pH, um dos fatores que afeta a interação de proteínas é a força iônica do meio, pois representa a concentração total de eletrólitos em um solução, podendo facilitar ou dificultar as interações de adsorção na interface do eletrodo [81]. 
Principalmente em plataformas que possuem DNA imobilizados em sua superfície, devido a presença de cargas negativas do grupo fosfato presente na cadeia de oligo [82].

Para verificar essa influência, montou-se o mesmo procedimento experimental citado na seção 3.1.4, e variou-se apenas o tipo de solução tampão utilizada na diluição das proteínas e nas medidas eletroquímicas. Duas soluções foram testadas, o tampão PBS $\left(137 \mathrm{mM} \mathrm{NaCl}+2,7 \mathrm{mM} \mathrm{KCl}+1 \mathrm{mM} \mathrm{Na}_{2} \mathrm{HPO}_{4}+0,18 \mathrm{mM}\right.$ $\mathrm{KH}_{2} \mathrm{PO}_{4}$, pH 7,4) e o tampão BB $\left(30 \mathrm{mM}\right.$ Tris $+150 \mathrm{mM} \mathrm{NaCl}+1 \mathrm{mM} \mathrm{MgCl}_{2}$, pH 7,5 - BB) proposto por Kyung et al. [69].

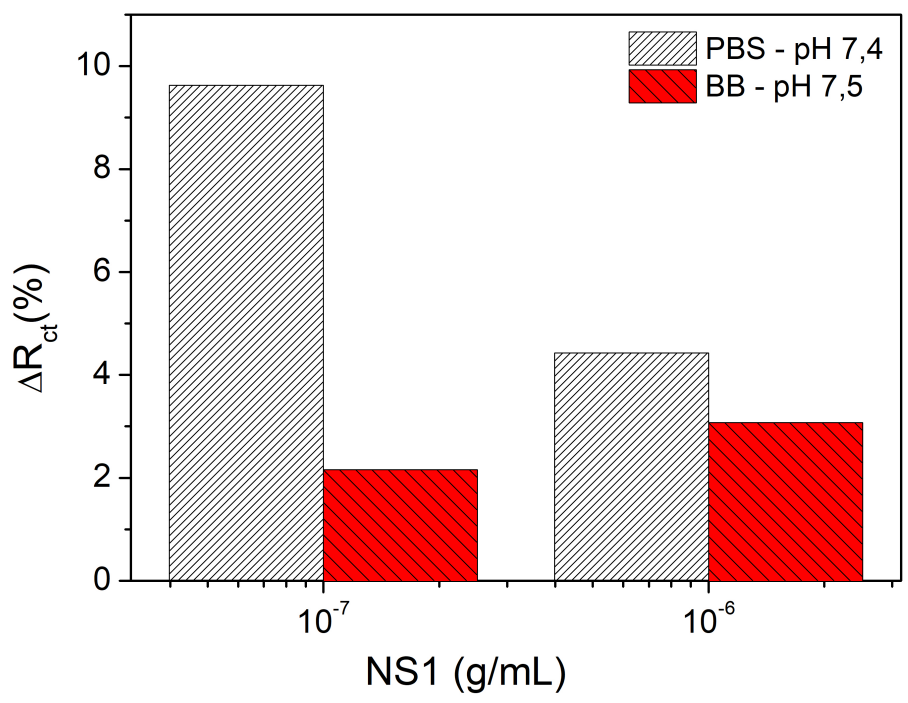

Figura 3.9: Variação da resistência à transferência de carga em função da concentração de NS1 diluída nos tampões: fosfato salino - PBS pH 7,4 (coluna branca com linhas agrupadas); binding - BB $p H$ 7,5 (coluna vermelha com linhas dipersas).

A variação da $R_{c t}(\%)$ com relação ao tipo de tampão é representada na Figura 3.9 para duas concentrações distintas de NS1. O resultado mostra como as diferenças entre as composições dos tampões, mais precisamente a presença do sódio, aumenta a força iônica da solução, favorecendo a interação da NS1 [82].

\subsubsection{Uso do BSA na Solução}

O estudo da estabilidade da NS1 se baseou principalmente na literatura, onde pesquisadores demonstraram que nas células humanas infectadas com o vírus da 
Dengue a NS1 existe em forma de monômero. Porém, para ser secretada na corrente sanguínea, os monômeros agrupam-se com a ajuda do retículo endoplasmático, formando um hexâmero [13]. Essa conformação é composta de três dímeros com um núcleo hidrofóbico e sensível a detergentes que leva consigo uma carga de 70 lipídeos, semelhante a uma lipoproteína de alta densidade. Essa concentração de lipídeos por sua vez ajudam as formas secretadas da NS1 a segregarem nas paredes celulares das outras células por meio dos glicoaminoglicanos [83]. Muller et al. confirmam que a forma secretada de NS1 é hexamérica, porém complementar que suas ligações entre dímeros são formadas pelos 12 resíduos de cisteínas que se ligam em seis pontes di-sulfetos [84]. Kyung e colaboradores sugerem o uso do tampão binding com $0,1 \%$ de BSA em suas medidas. Tal observação é válida, pois esse tipo de proteína possui 35 resíduos de cisteína [85] podendo se ligar com NS1 pelas pontes di-sulfetos, estabilizando-a. Para isso, montou-se todo protocolo experimental da seção 3.1.4 para testar se a diluição da NS1 em solução com BSA alterava o sinal, partindo de uma diluição maior $(10 \mathrm{pg} / \mathrm{mL}$ a $1 \mu \mathrm{g} / \mathrm{mL})$ das utilizadas nas seções anteriores.

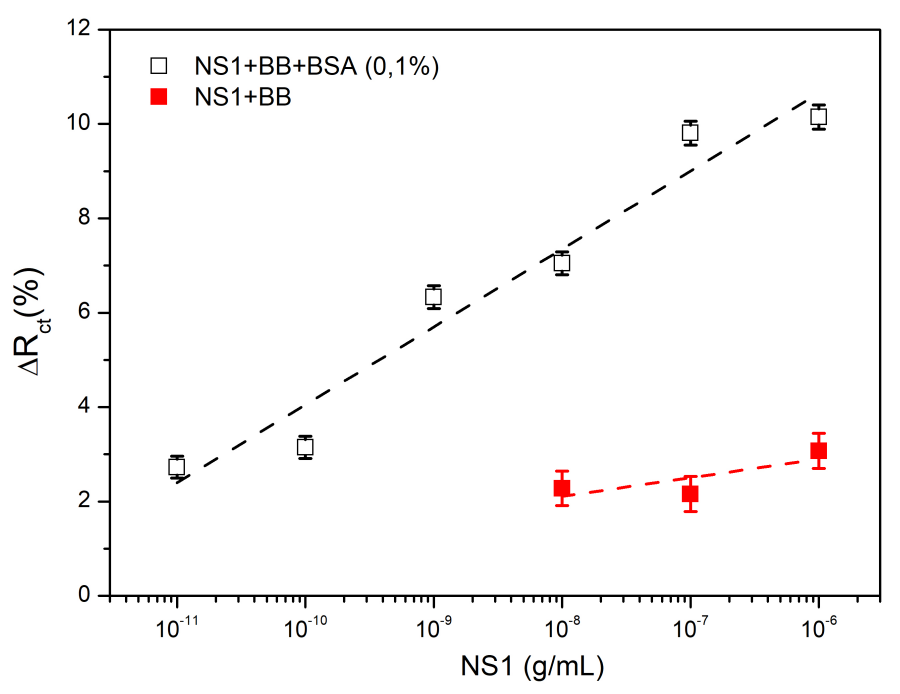

Figura 3.10: Variação de $R_{c t}(\%)$ em função da concentração de NS1 diluída em: tampão binding (BB) com BSA (quadrado aberto); e tampão BB sem a adição de BSA (círculo fechado). A linha pontilhada preta representa uma regressão linear do sistema com a adição de BSA. A linha pontilhada vermelha representa a mesma forma de regressão, porém com o sistema sem BSA. 
A Figura 3.10 mostra a variação linear da resistência à transferência de carga com o aumento das concentrações de NS1 em BB + BSA $(0,1 \%)$ no dispositivo. Pela regressão linear, o uso do BSA na solução traz sensibilidade elevada $(1,65 \pm$ $0,18 \%$ por década, $\left.\mathrm{R}^{2}=0,94\right)$ em comparação com a solução sem BSA $(0,39 \pm 0,29$ $\%$ por década, $\left.\mathrm{R}^{2}=0,27\right)[86]$.

Ao se comparar os sistemas propostos, é possível notar de forma bem clara como o uso do BSA pode influenciar na estabilização da proteína, pois para uma concentração de $1 \mathrm{ng} / \mathrm{mL}$ tem-se um sinal de 2,27\% (sem BSA) em comparação com 7,05\% (com BSA). Além disso, é possível notar um crescimento e não um decaimento do sinal conforme visto nas seções 3.2.3.1 e 3.2.3.2. Tais resultados indicam que o uso do BSA é de grande importância na estabilização da proteína alvo, sendo adotado para a realização dos experimentos posteriores.

\subsubsection{Estabilização da SAM}

O BSA é amplamente utilizado como bloqueador na superfície de plataformas eletroquímicas para evitar interações não específicas. Com a adoção do BSA na diluição da NS1, é necessário garantir que o próprio BSA não interaja de forma não específica com a superfície. A molécula de BSA possui 17 ligações di-sulfetos formadas por 34 cisteínas e 1 cisteína livre [83, 85], o que favorece sua adsorção com a superfície do ouro [87]. Como o sinal da EIE depende da interação com a superfície, essa adsorção desta molécula levaria a um sinal falso positivo. Para verificar essas interações, montou-se dois sistemas com o protocolo já descrito na seção 3.1.4 com algumas alterações:

1. A superfície do eletrodo foi montada apenas com MCH e após 16 h parte dos eletrodos foram bloqueados com BSA e a outra parte não. A Figura 3.11a mostra os resultados da variação da resistência à transferência de carga em função da concentração de NS1 para esse sistema;

2. A plataforma foi funcionalizada com a SAM na proporção padrão (1:50) e posteriormente parte dos eletrodos teve sua superfície bloqueada com BSA e outra parte não, porém possuindo ainda assim o BSA utilizado na solução com NS1. Os valores de resistência à transferência de carga em função da 
concentração de NS1 obtidos da EIE para esse sistema estão agrupados na Figura 3.11b.
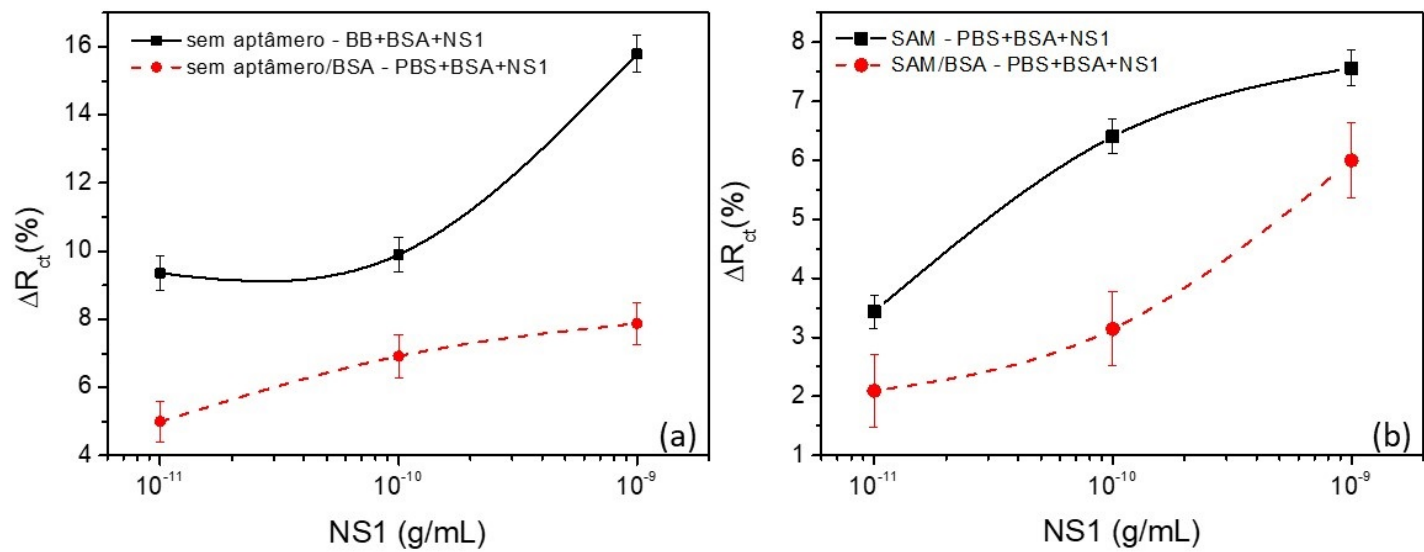

Figura 3.11: Resposta da $\Delta R_{c t}(\%)$ em função da concentração de NS1 para os dois sistemas montados: a) superfície montada $M C H$ e NS1 diluída em BSA+BB - quadrado fechado e superfície montada com MCH, bloqueada com BSA e com NS1 diluída em PBS $+B S A$ (círculo fechado); b) SAM montada com aptâmero + MCH e NS1 em PBS+BSA (quadrado fechado) e SAM com bloqueio de BSA e NS1 em PBS+BSA (círculo fechado). As linhas tracejadas e continuas não representam qualquer operação matemática sendo apenas um guia.

A Figura 3.11 permite observar que o sistema descrito pelo tópico I acima confirma que existe a interação não específica na superfície, pois mesmo sem o aptâmero é possível obter um aumento de $16 \%$ para $1 \mathrm{ng} / \mathrm{mL}$ no sinal. Também é possível notar que mesmo após o bloqueio há um crescimento do sinal com o aumento da concentração NS1, esse aumento pode estar associado à própria NS1 que pelo seu resíduo cisteína possa interagir inespecificamente.

A metodologia adotada pelo tópico 2 permite analisar o comportamento da SAM com a presença/ausência do BSA como bloqueio de superfície. Ao analisar a Figura 3.11b apenas para o modelo com bloqueio, é possível notar um aumento significativo na resistência à transferência de carga, menor que o modelo sem bloqueio. Esse aumento de sinal traz uma interpretação mais correta ao sistema, pois como o BSA já bloqueou toda a superfície, a mudança é apenas proveniente da interação entre o aptâmero e a NS1. Assim, o bloqueio de superfície com BSA foi definido como parâmetro essencial na funcionalização da SAM. 


\subsection{Caracterização por AFM}

A imagem por AFM é realizada por meio da reconstrução da topografia em uma imagem tridimensional e pelos parâmetros de rugosidade $(R)$ [64, 65]. A Figura 3.12 ilustra as imagens obtidas de diferentes etapas da modificação do eletrodo de ouro. Em (a) está o eletrodo limpo e em (b) modificado com MCH com resolução de $2,5 \times 2,5 \mu \mathrm{m}^{2}$. Novamente em (c) e (d) o eletrodo limpo e modificado apenas com $\mathrm{MCH}$ com uma resolução maior $\left(1,00 \times 1,00 \mu \mathrm{m}^{2}\right)$. A imagem (e) mostra a superfície após a co-immobilização do aptâmero com MCH (Figura 3.12e) na proporção otimizada. Em (f) a superfície pós-bloqueio (SAM/BSA) representando a interação da NS1 $(1 \mu \mathrm{g} / \mathrm{mL})$ com o aptâmero.

A Tabela 3.1 apresenta os valores de $\mathrm{R}_{a}$ obtidos para as imagens da Figura 3.12 , mostrando que os resultados tanto para a menor $\left(2,5 \times 2,5 \mu \mathrm{m}^{2}\right)$ quanto para a maior resolução $\left(1,0 \times 1,0 \mu \mathrm{m}^{2}\right)$ dos eletrodos limpos e os modificados com MCH apresenta uma redução da rugosidade (8,9 para 4,8 nm e 9,3 para 4,0 $\mathrm{nm}$ respectivamente).Esta redução da rugosidade representa a adsorção rápida do MCH nos vales, suavizando a superfície. $\mathrm{O}$ valor de $\mathrm{R}_{a}$ para apenas a SAM apresentou um aumento (4,9 nm) em comparação ao modificado apenas com $\mathrm{MCH}(4,0 \mathrm{~nm})$, o que representa a adsorçao não somente do $\mathrm{MCH}$, mas também do aptâmero (que possui uma cadeia relativamente maior que o espaçador).Com a adição do bloqueio com BSA e a interação com a NS1 $(6,3 \mathrm{~nm})$, é possível notar novamente um aumento do coeficiente de rugosidade, confirmando a interação da proteína com a superfície receptora. Os valores dos demais parâmetros de rugosidade se encontram no Apêndice (Tabela A.1). 

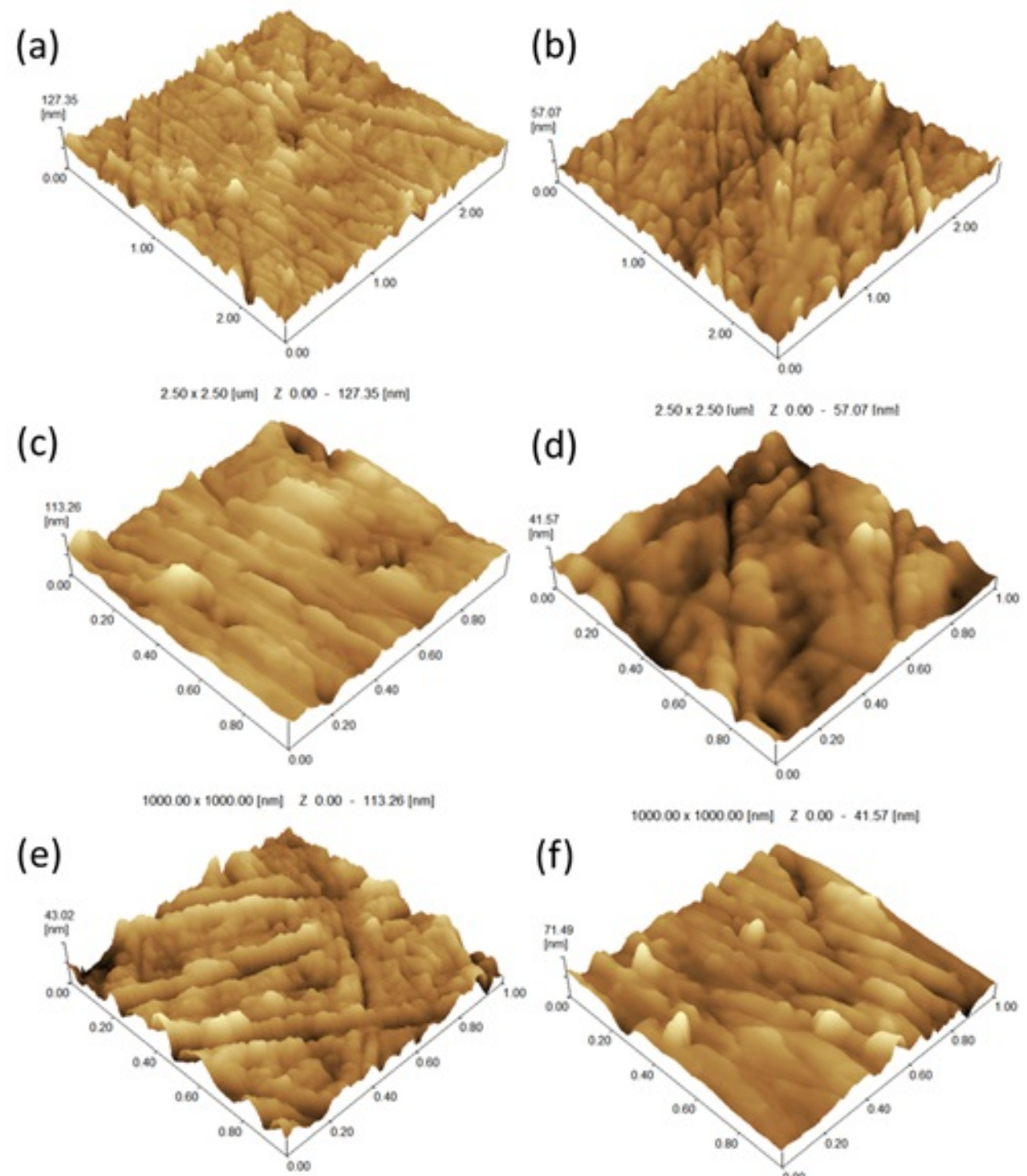

$100000 \times 100000[\mathrm{~mm}] \quad z 0.00-4300[\mathrm{~mm}]$

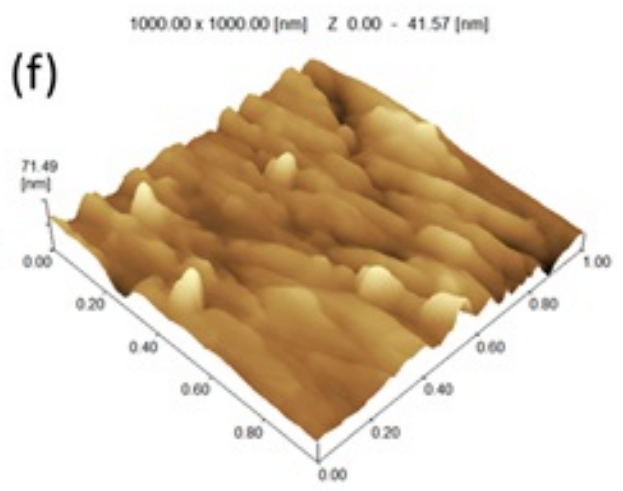

$100000 \times 100000 \mathrm{lnm}] \mathrm{Z} 0.00 \cdot 71.49[\mathrm{~nm}]$

Figura 3.12: Imagem de microscopia de força atômica de um eletrodo de ouro em diferentes etapas: (a) limpo e modificado com $M C H$ (b) em uma resolução macro (2,5 $x$ 2,5 $\mu \mathrm{m})$; (c) limpo e modificado com $\mathrm{MCH}$ (d) em um resolução micro $(1,0 x$ 1,0 $\mu \mathrm{m})$; (e) Formação da SAM e (f) SAM com bloqueio de BSA e $1 \mu \mathrm{g} / \mathrm{mL}$ de NS1. 
Tabela 3.1: Resultados da rugosidade aritmética $\left(R_{a}\right)$ para cada etapa desenvolvida no eletrodo de ouro.

\begin{tabular}{c|cc}
\hline Superfície & Resolução $(\mu \mathrm{m})$ & Rugosidade $\left(\mathrm{R}_{a}\right)(\mathrm{nm})$. \\
\hline Limpo & $2,5 \times 2,5$ & $8,9 \pm 3,5$ \\
MCH & $2,5 \times 2,5$ & $4,8 \pm 5,2$ \\
Limpo & $1,0 \times 1,0$ & $9,3 \pm 1,9$ \\
MCH & $1,0 \times 1,0$ & $4,0 \pm 1,5$ \\
SAM & $1,0 \times 1,0$ & $4,9 \pm 1,2$ \\
SAM $/$ BSA $+\mathrm{NS} 1$ & $1,0 \times 1,0$ & $6,3 \pm 2,58$ \\
\hline
\end{tabular}




\section{Capítulo}

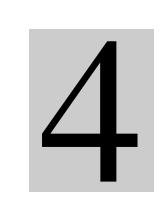

\section{BIOSSENSOR IMPEDÂNCIOMÉTRICO}

Após o desenvolvimento da metodologia e otimização dos parâmetros, descritos no Capítulo 3, foi necessário avaliar a performance do biossensor. Assim, neste capítulo são apresentados os melhores resultados obtidos para densidade de aptâmeros na superfície da plataforma, potencial aplicado, curva analítica e seus respectivos parâmetros e controle negativo.

\subsection{Espectroscopia de Impedância Eletroquímica}

A metodologia final obtida para o aptâmero e para NS1 se inicia com o aquecimento do aptâmero por 10 minutos à $95{ }^{\circ} \mathrm{C}$ e diluído imediatamente no tampão SELEX por 40 minutos. Posteriormente é adicionado um volume de $\mathrm{MCH}$ (1 mM 10\% etanol) referente à proporção otimizada (1:150). O eletrodo de ouro previamente tratado e limpo é então co-imobilizado com essa solução, e levado em uma câmara úmida à $4{ }^{\circ} \mathrm{C}$ por 18 horas.

Após este período, os eletrodos são submetidos a três soluções de limpeza (200 mM PB; 10 mM PB + EDTA; e 10mM PB) por 5 minutos cada, seguido do "backfilling" com MCH (1 mM 10\% etanol) por 1 hora e, por fim, são colocados em tampão PBS (pH 7,4) para estabilizar por 2 horas. Depois destas etapas, são realizadas medidas de EIE até constatar a estabilização da SAM, onde, os eletrodos são imobilizados novamente com uma solução de PBS $(\mathrm{pH} 7,4)+$ BSA $(0,1 \%)$ por 30 minutos para o bloqueio da superfície.

O preparo da NS1 consiste na diluição da mesma em uma solução de PBS $(\mathrm{pH} 7,4)+\operatorname{BSA}(0,1 \%)$ até atingir as concentrações desejadas. 
As medidas de EIE são realizadas com o potencial de circuito aberto (OCP) vs $\mathrm{Ag} / \mathrm{AgCl}$. Após o bloqueio com BSA, os valores de OCP são fixos individualmente (entre 0,210 e 0,230 V) e todas as análises subsequentes obtidas estão sobre este mesmo potencial.

\subsection{Otimização da proporção entre aptâmero e $\mathrm{MCH}$}

A formação da SAM é governada majoritariamente pela co-imobilização entre aptâmero e MCH [52]. O estudo desta organização se dá pela variação das proporções entre as duas moléculas marcadas com tiol. Para isso, variou-se a proporção entre aptâmero e total de tiol na superfície dos eletrodos de 1:25 até 1:200. Os demais procedimentos foram realizados conforme já otimizado nas seções anteriores. Assim, após a preparação da SAM, a mesma foi bloqueada com BSA e testada para uma concentração fixa de $100 \mathrm{pg} / \mathrm{mL}$ de NS1 (utilizando também BSA). Os resultados são apresentados na Figura 4.1.

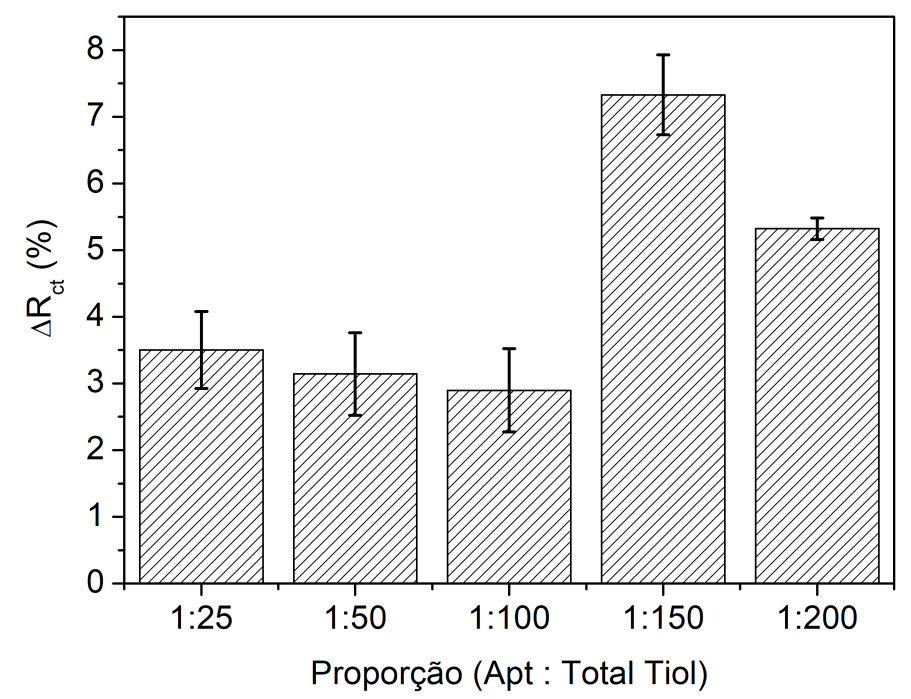

Figura 4.1: Variação da resistência à transferência de carga $\left(\Delta R_{c t}(\%)\right)$ em função das proporçôes (aptâmero : total tiol) para a concentração de $100 \mathrm{pg} / \mathrm{mL}$ de NS1.

A Figura 4.1 apresenta a variação do sinal em função da densidade de aptâmero, onde o máximo de sinal (aproximadamente 8\%) demonstrado pela 
proporção 1:150. Dessa forma, é adotou-se este valor como a proporção otimizada ou padrão para os demais experimentos.

\subsection{Potencial aplicado - OCP vs $\mathrm{E}_{i n}$}

Conforme descrito na seção 2.1.2.1, o potencial mais utilizado nas aplicações da EIE é o de circuito aberto (OCP), que surge da interação do eletrodo de trabalho com o meio, no caso, a solução eletrolítica de tampão PBS com o par redox Ferri/Ferro. Entretanto, também é possível utilizar a voltametria cíclica para estudar o potencial que permite a máxima transferência eletrônica através da SAM.

Assim, para testar o potencial aplicado, a mesma plataforma foi funcionalizada e testada pela EIE tanto através do OCP quanto utilizando a VC para determinar o potencial de meia onda. Neste caso, a VC foi realizada com velocidade de varredura de $50 \mathrm{mV} / \mathrm{s}$ no intervalo 0,7 a - 0,2 V (vs $\mathrm{Ag} / \mathrm{AgCl}$ ), em uma solução eletrolítica PBS + 2,5 mM Ferri/Ferro.
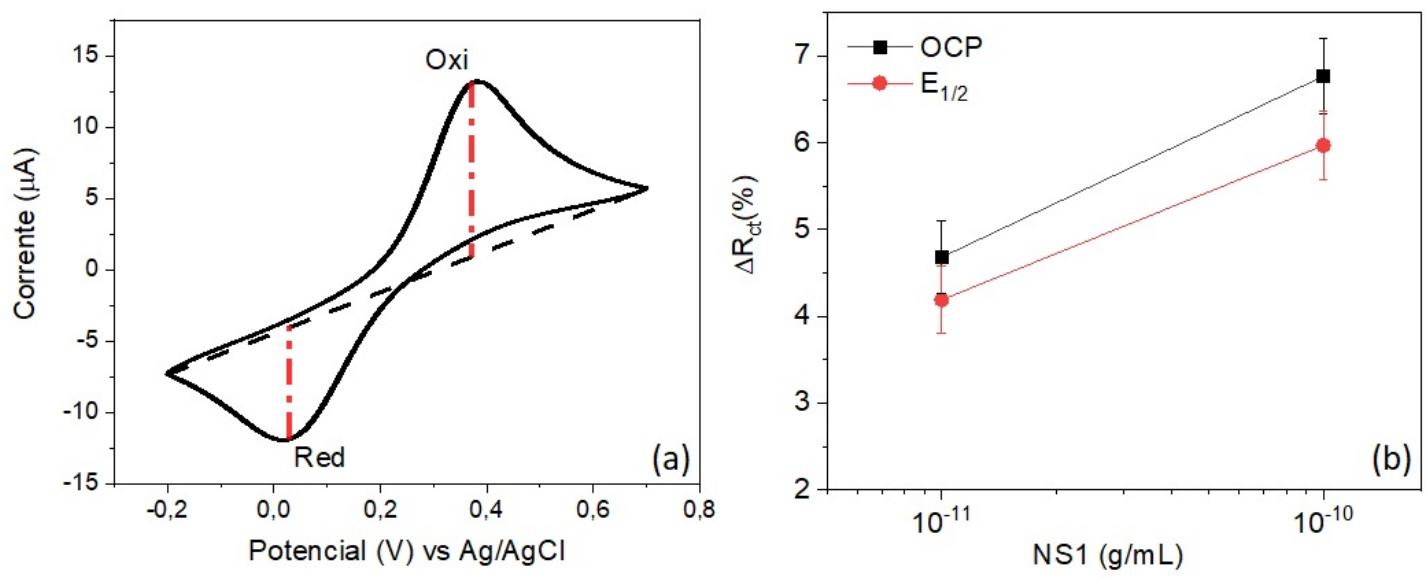

Figura 4.2: Resultados proveniente das técnicas: a) voltametria cíclica com a representação dos potenciais de oxidação (Oxi) e redução (Red), a linha tracejada representa um guia do potencial inicial ao final; b) espectroscopia de impedância eletroquímica para os potenciais de OCP (quadrado fechado) e potencial $E_{\text {in }}$ (círculo fechado).

Após a VC, encontrou-se os picos de oxidação (Oxi) e redução (Red) (Figura 4.2a) e com a expressão 2.33, obteve-se o potencial $\mathrm{E}_{\text {in }}$ a ser utilizado na impedância. Em ambos os casos, os eletrodos foram expostos a duas concentrações de NS1 (10 e $100 \mathrm{pg} / \mathrm{mL}$ ) em PBS pH 7,4 e os resultados da variação percentual da $R_{c t}$ estão 
presentes na Figura 4.2b.

$\mathrm{O}$ valor obtido para o potencial de meia onda $\left(\mathrm{E}_{\text {in }}=0,207 \mathrm{~V}\right)$ pela equação $2.33\left(\mathrm{E}_{\text {red }}=0,039 \mathrm{~V}\right.$ e $\left.\mathrm{E}_{\text {oxi }}=0,376 \mathrm{~V}\right)$ não diferiu do potencial de circuito aberto (OCP) de 0,227 V. Embora a diferença entre ambos seja pequena (20 mV), os resultados presentes na Figura 4.2b demonstram que o potencial de circuito aberto gerou um sinal impedânciométrico mais intenso em comparação com o potencial de meia onda. A única hipótese levantada por esse aumento de sinal é de que a VC possa ter perturbado a SAM afetando a interação da NS1 com o aptâmero.

\subsection{Curva Analítica}

Para avaliar a performance do biossensor é necessária a construção de uma curva analítica para diversas concentrações de NS1. A Figura 4.3 mostra o aumento da resistência à transferência de carga para diferentes concentrações de NS1 em três meios (PBS, soro + PBS (50\%) e soro $100 \%$ ), partindo de $10 \mathrm{pg} / \mathrm{ml}$ e aumentando em um fator de 10 até atingir $1 \mu \mathrm{g} / \mathrm{mL}$. Cada concentração foi colocada na superfície da plataforma, já bloqueada, por 30 minutos, sendo realizadas as medições consecutivas. Cada concentração foi repetida em pelo menos três eletrodos independentes. A Tabela B.1, no Apêndice B, compreende todos os dados obtidos para a construção da curva analítica. A Figura B.2 no apêndice B ilustra o diagrama de Nyquist da curva analítica experimental com o ajuste do modelo pelo circuito equivalente de randles. Nesta imagem (Figura B.2) também é possivel constatar a establidade do sistema, observando-se uma resposta linear do sinal com as crescentes concentrações de NS1.

As linhas presentes na Figura 4.3 (pontilhada, tracejada e contínua) representam as regressões lineares [86]. De acordo com Armbruster et al. [88], o limite de detecção (do inglês limit of detection - LoD) pode ser encontrado com os dados da regressão dentro de uma determinada faixa linear, conforme a equação 4.1:

$$
L o D=3,3 \frac{\sigma}{a}
$$




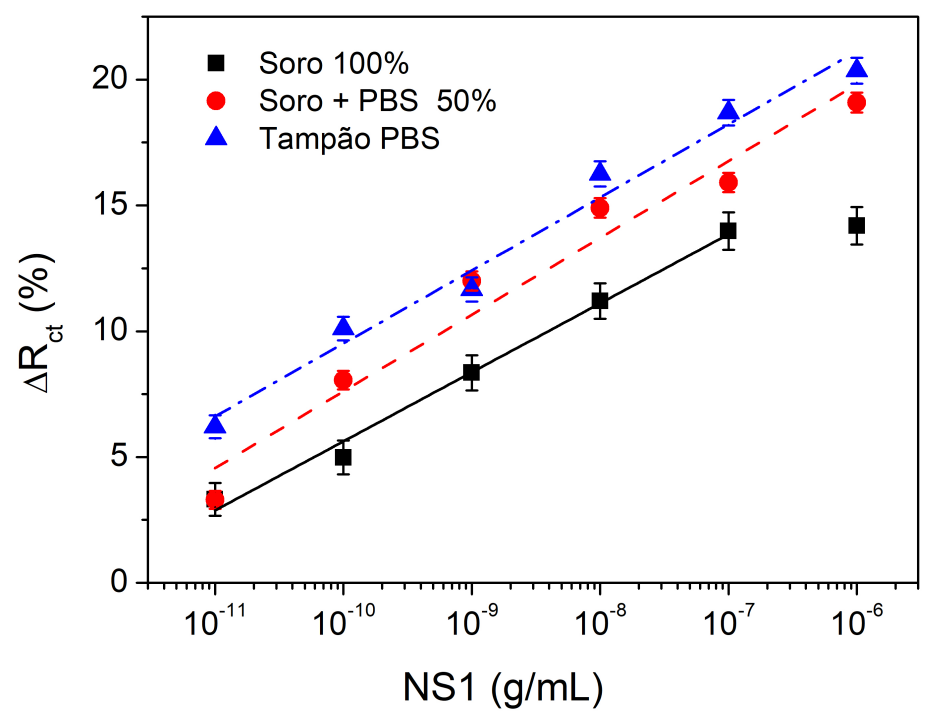

Figura 4.3: Aumento do $\Delta R_{c t}(\%)$ em função da concentração de NS1 para três meios: PBS(linha azul pontilhada); Soro + PBS (50\%) (linha vermelha tracejada); Soro 100\% (linha preta continua).

$$
\sigma=\sqrt{\frac{R S S}{n-1}}
$$

Sendo a o coeficiente linear da reta, $\sigma$ o desvio padrão das medidas, RSS é a soma dos quadrados do resíduo e n é o número de pontos. Pela regressão é possível notar o aumento do $\Delta \mathrm{R}_{c t}(\%)$ em toda a faixa linear para os meio que possuem tampão, enquanto no meio com apenas soro (linhas contínua preta) ocorre um processo de saturação devido ao grande número de biomoléculas presente no mesmo [86, 89]. A Tabela 4.1 apresenta os valores de LoD encontrados em suas respectivas faixas lineares, bem como seus valores de sensibilidade para cada meio.

Em comparação com a faixa clínica $\left(0,04\right.$ a $2 \mu \mathrm{g} / \mathrm{mL}$ para $1^{a}$ infecção e 0,01 a 2 $\mu \mathrm{g} / \mathrm{mL}$ para $2^{a}$ infecção) os aptasensores desenvolvidos neste trabalho apresentaram um LoD inferior a esta faixa, o que favorece a deteç̧ão em baixas concentrações, com região linear de detecção de 10 pg/mL até 100 ng/mL.

Ao se comparar os limites obtidos com os presentes na literatura para os últimos 5 anos (Tabela 4.2), o dispositivo desenvolvido apresentou o menor valor, indicando sua alta sensibilidade na detecção da NS1. Além disto, os aptassensores são de características inovadoras, principalmente na detecção de 
Tabela 4.1: Parâmetros obtidos pela regressão linear e pelo cálculo do limite de detecção para a EIE.

\begin{tabular}{|c|c|c|c|}
\hline & $\begin{array}{c}\text { Tampão PBS + BSA } \\
(0,1 \%)\end{array}$ & $\begin{array}{l}\text { Soro Humano }+ \text { PBS } \\
(50 \%)\end{array}$ & $\begin{array}{c}\text { Soro Humano } \\
\text { comercial }(100 \%)\end{array}$ \\
\hline Faixa Linear & $10 \mathrm{pg}-1 \mu \mathrm{g} / \mathrm{mL}$ & $10 \mathrm{pg}-1 \mu \mathrm{g} / \mathrm{mL}$ & $10 \mathrm{pg}-100 \mathrm{ng} / \mathrm{mL}$ \\
\hline $\mathrm{R}^{2}$ & 0,98 & 0,95 & 0,99 \\
\hline LoD & $1,29 \mathrm{pg} / \mathrm{mL}$ & $0,12 \mathrm{pg} / \mathrm{mL}$ & $1,22 \mathrm{pg} / \mathrm{mL}$ \\
\hline $\begin{array}{l}\text { Sensibilidade } \\
\text { (\% por década) }\end{array}$ & 2,9 & 3 & 2,7 \\
\hline RSS* & $11,52^{*}$ & $44,32^{*}$ & $1,41^{* *}$ \\
\hline
\end{tabular}

* Média do desvio padrão calculado por todos os pontos da curva analítica ** Média do desvio padrão calculado pelos os pontos dentro da faixa linear da curva analítica

doenças negligenciáveis como a Dengue. 


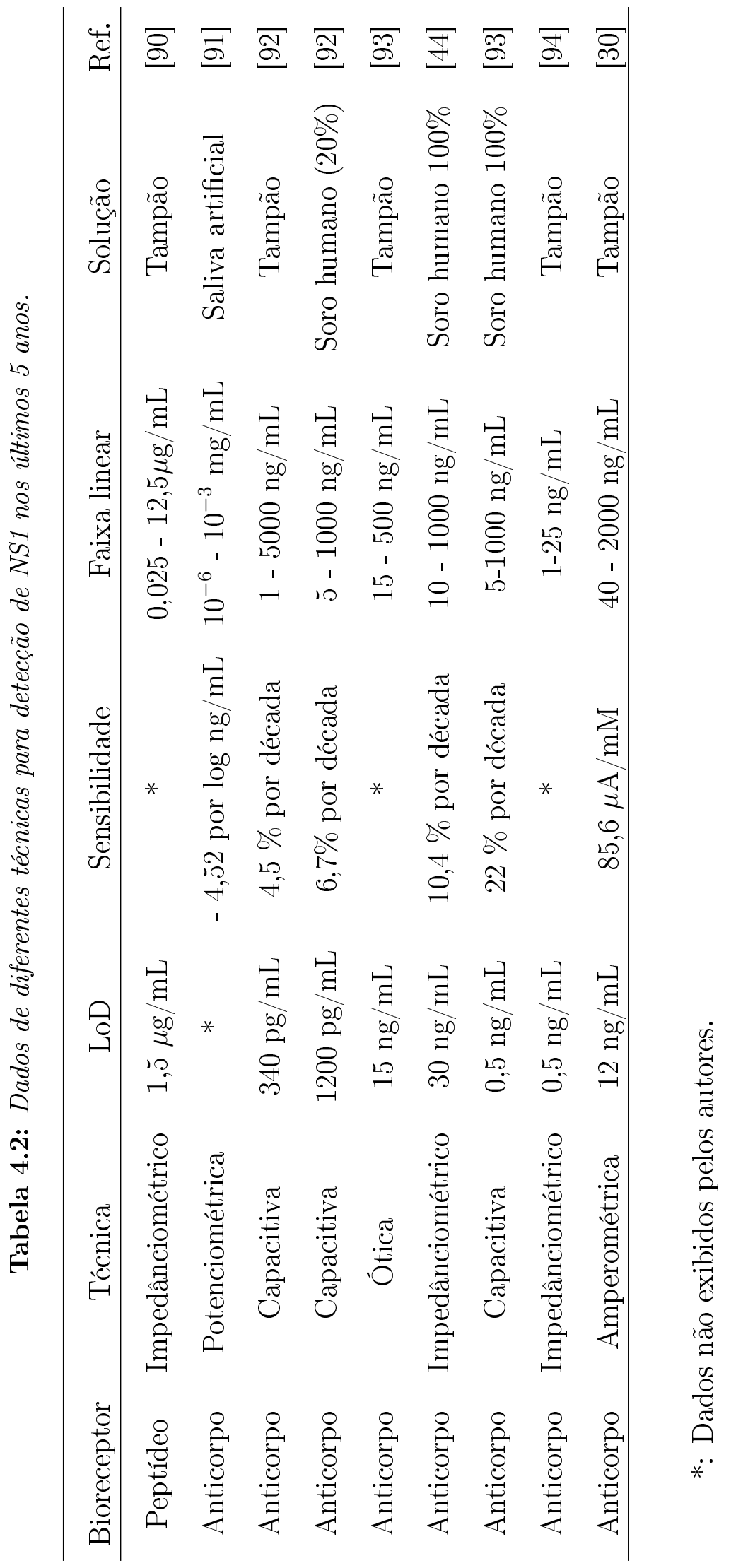




\subsection{Controle Negativo}

A Figura 4.4 abaixo ilustra o teste de controle negativo com outra proteína produzida pelo genoma viral da Dengue: Proteína do envelope (E), com aproximadamente $12 \mathrm{kDa}$, responsável por boa parte da neutralização dos anticorpos após a infecção [95]. Os eletrodos foram expostos a uma concentração de $1 \mathrm{ng} / \mathrm{mL}$ das proteínas NS1, E diluídas em soro comercial por 30 minutos. Conforme apresentado na Figura 4.4, a variação de sinal para a NS1 (8 \%) se mostrou superior à E (-4 \%), apresentando uma variação de $12 \%$ entre ambos sinais. Os valores negativos da Proteína E representam que houve um decréscimo do $\mathrm{R}_{c t}$, ou seja, a proteína alvo utilizada apresenta propriedades que facilitam o processo oxi-redox do Ferri/Ferro.

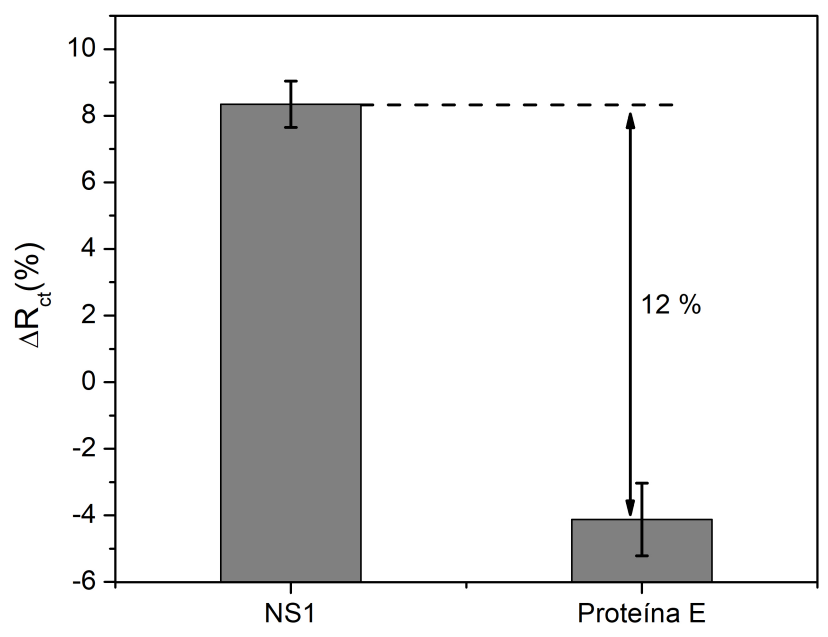

Figura 4.4: Controle negativo. Comparaçôes de $\Delta R_{c t}(\%)$ em função da NS1 e da proteina $E$.

\subsection{Conclusões Parciais}

A caracterização eletroquímica do biossensor formado por uma SAM de aptâmeros e MCH foi realizada pela técnica de espectroscopia de impedância eletroquímica. O sistema montado apresentou um limite de detecção de 1,29, 0,12, 
e $1,22 \mathrm{pg} / \mathrm{mL}$ para os meios de PBS, PBS + soro comercial (50\%) e soro humano comercial $100 \%$, respectivamente. Atrelado a este resultado, a sensibilidade obtida foi de 2,9, 3 e 2,7 \% por década. Tais valores estão abaixo da faixa clínica $(0,04$ a $2 \mu \mathrm{g} / \mathrm{mL}$ para $1^{a}$ infecção e 0,01 a $2 \mu \mathrm{g} / \mathrm{mL}$ para $2^{a}$ infecção) e dos dispositivos apresentados na literatura, o que fortalece seu uso para a detecção da NS1 em seus estágios iniciais da doença. Além disto, o dispositivo montado com aptâmeros possui características inovadoras, visto que ainda não se encontram trabalhos na literatura. Ao ser submetido com outra molécula da Dengue (Proteína E), o aptassensor desenvolvido se mostrou seletivo na detecção da NS1. 


\section{CAPÍtulo}

\section{BIOSSENSOR CAPACITIVO}

Entre os tipos de biossensores, os capacitivos têm chamado grande atenção nos últimos anos devido à alta sensibilidade. Desta forma, a plataforma impedimétrica foi modificada para realização de medidas de capacitância. Neste capítulo serão abordados os métodos utilizados para funcionalização da SAM e a avaliação da performance do biossensor como uma plataforma capacitiva.

\subsection{Espectroscopia de capacitância eletroquímica}

A Espectroscopia Capacitância Eletroquímica utiliza o modo não-faradaico para aquisição do sinal, onde não há um marcador redox externo, de forma que as análises das variações ocorridas na capacitância interfacial são devidas à remoção de moléculas de água e íons da superfície do eletrodo após a ligação com o analito alvo.

Conforme descrito por Santos et al. [57], a imersão dos eletrodos em uma solução sem cargas redox e a subsequente aplicação de um potencial causa uma orientação das cargas carregadas e dos dipolos na interface eletrodo/solução, gerando novamente uma capacitância de dupla camada elétrica, aumentado a sensibilidade do sistema para quaisquer mudanças interfaciais [56].

A resposta do modelo capacitivo segue as equações 2.30 e 2.31 descritas na seção 2.1.2.2, onde ocorre a conversão do sinal impedimétrico real (Z') e imaginário (-Z”) nos sinais capacitivos reais (C') e imaginários (C"). Por ser um sistema não-faradaico, as medidas são realizadas em meio PBS (pH 7,4), e os valores de capacitância são analisados a partir da máxima fase $\left(^{\circ}\right)$ encontrada para cada 
eletrodo (Figura 5.1a). Este sinal implica que para determinada frequência $(\omega)$, é possível obter o máximo de sinal do efeito capacitivo [93, 94] . A Figura 5.1 a ilustra um gráfico de fase em função do logaritmo da frequência com sua amplitude máxima em $1,7 \mathrm{~Hz}$, indicando uma fase de aproximadamente $86^{\circ}$. Neste valor de frequência da máxima fase serão analisados os dados de capacitância em função das diferentes concentrações de NS1 (Figura 5.1b).
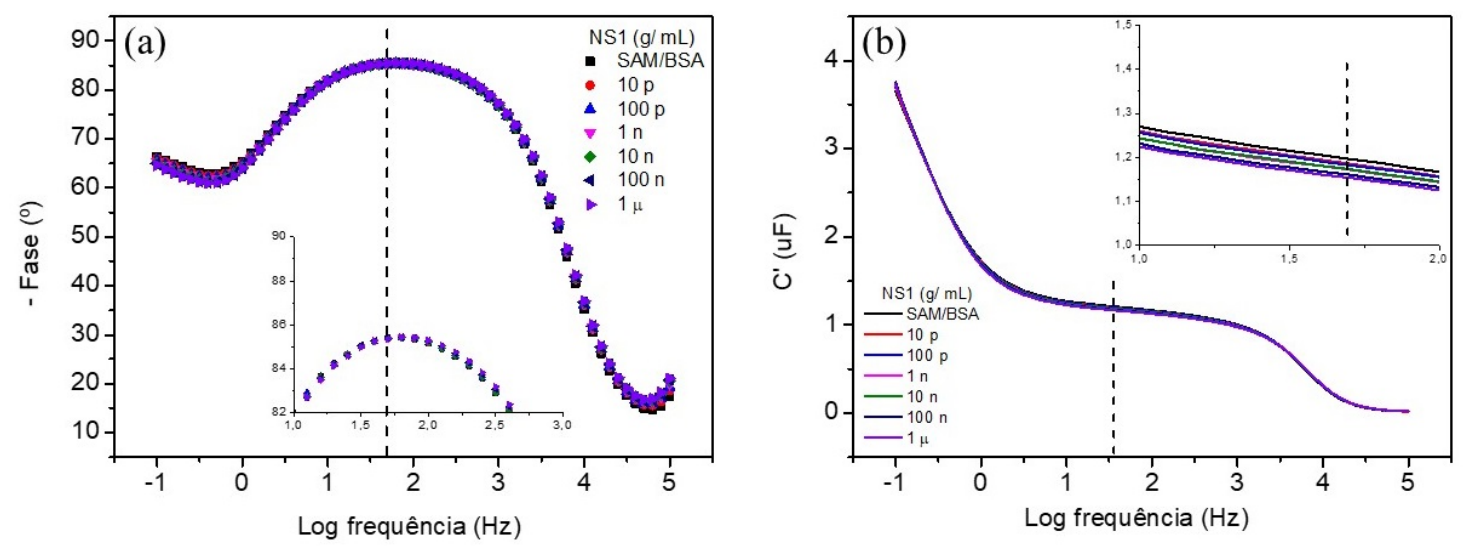

Figura 5.1: Representação esquemática dos (a) Ângulos de fase em função da frequência obtidos pela EIS; (b) dados de capacitância obtidos para diferentes concentraçôes de NS1 (10 pg para $1 \mu \mathrm{g} / \mathrm{mL}$ ).

É possível notar na Figura 5.1b que a capacitância do sistema decresce quase linearmente em função do aumento da concentração de NS1, indicando que a interação da proteína com o aptâmero altera as propriedades dielétricas da interface, realocando os íons solvatados e as moléculas de água adsorvidas na superfície [96], pois os processos cinéticos e termodinâmicos das reações redox interfaciais são fortemente afetadas pela natureza do meio qual elas ocorrem.

\subsubsection{Funcionalização da SAM}

A funcionalização da SAM no modelo capacitivo é possível pela adição do 6-(Ferrocenil)hexanotiol (FCC) como carga confinada. Umas das propriedades desta molécula é a presença de dois estados redox: um estado natural e outro estado oxidado. Por ser um complexo organometálico, o FCC possui propriedades hidrofóbicas, sendo muito utilizado como marcador em meios não aquosos [97]. Ao ser adicionado em meios aquosos, ocorre uma dominância do processo difusional na 
solução, levando o ferroceno próximo à superfície do ouro. Ao se aproximar do ouro, a ligação S-H é favorecida [98], de forma que a molécula de FCC se reorganiza na superfície.

Em contato com a superfície e na presença de um potencial, o centro redox do ferroceno se oxida, acumulando cargas na interface do eletrodo e consequentemente aumentando seu valor capacitivo [99], sendo capaz de gerar assim uma alta taxa de transferência de elétrons entre a interface e a superfície [100]. Assim, a primeira otimização realizada se baseia em analisar o tempo necessário para o FCC se adsorver e se reorganizar. Para isso, duas formas de co-imobilização e "backfilling" foram montadas: a primeira solução continha aptâmeros e FCC (1 mM, 10\% etanol) a uma proporção de 1:150 em tampão Selex, sendo realizado um "backfilling"apenas com MCH (1 mM 10\% etanol); e a segunda continha aptâmeros e MCH (1 mM, $10 \%$ etanol) em uma proporção de 1:150, sendo feito um "backfilling"com FCC (1 mM, 10\% etanol). Ambas soluções de co-imobilização foram depositadas no eletrodo por 18 horas, e o "backfilling" foi realizado em sequência por 1 hora. Após este processo, os eletrodos foram bloqueados com BSA $(0,1 \%)$ em PBS e foram adicionadas diferentes concentrações de NS1 com BSA. A Figura 5.2 ilustra os resultados em variação de capacitância pelas diferentes concentrações de NS1.

A adsorção de moléculas alcanotioladas na superfície do eletrodo de ouro apresentam dois processos cinéticos distintos: uma primeira etapa de adsorção rápida, onde as moléculas se aproximam da superfície, com poucos minutos de duração; e uma etapa lenta, onde ocorre a reorganização das moléculas na superfície até que atinjam sua angulação ideal, podendo demorar várias horas [76]. Para superfície com diferentes moléculas alcanotioladas, parâmetros como interações entre estas cadeias e até o tamanho da mesma podem influenciar na sua velocidade da adsorção inicial, onde moléculas menores adsorvem mais rapidamente que as maiores e estas por sua vez, se estabilizam mais rápidas que as menores [67, 95, 98].

Como as moléculas de FCC e aptâmeros possuem a mesma quantidade de cadeias de alcanotióis (não levando em consideração as sequências oligos do aptâmero e o a molécula de ferro confinada), seus tempos de adsorção entre si são iguais, necessitando apenas de um tempo maior para sua reorganização e estabilização (interação de Van der Waals). Na aplicação do potencial, os centros confinados 


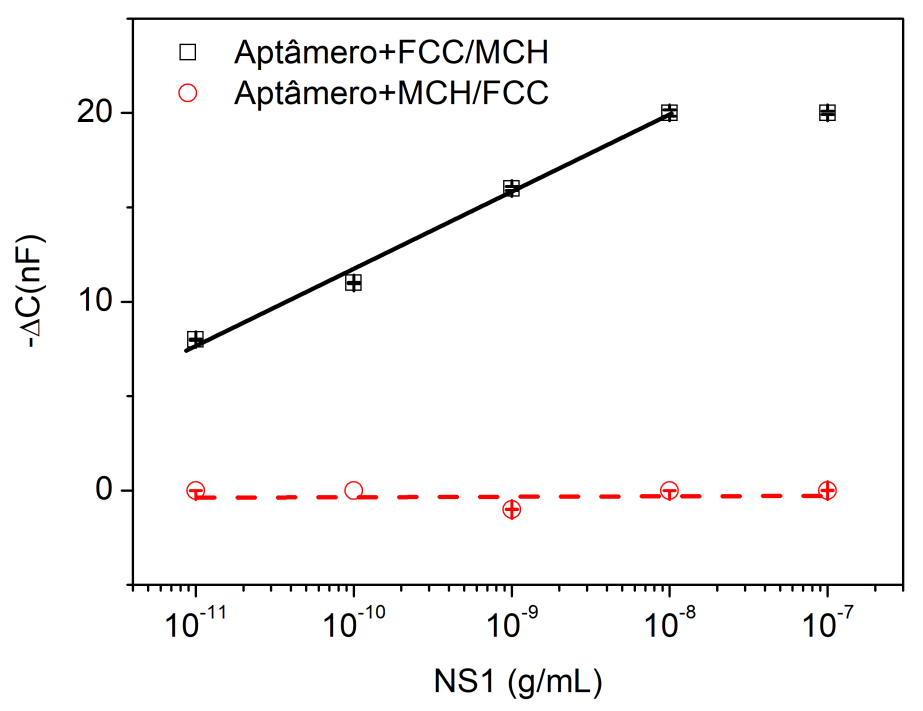

Figura 5.2: Variação na capacitância $(-\Delta C)$ em função das concentrações de NS1 para as duas formas distintas de co-imobilização e backfilling: Aptâmero + FCC com backfilling de $M C H$ (quadrados pretos e abertos); Aptâmero + MCH com backfilling de FCC (círculo aberto e vermelhos). As linhas pretas e tracejadas não são um ajuste, são um guia. ${ }^{*} O s$ erros foram obtidos pelo desvio padrão das amostras e, devido à sua grandeza não houve como apresentá-los no gráfico

estão oxidados e carregados, de forma que a adição da molécula alvo reduz sua carga, alterando assim seus valores capacitivos. Na Figura 5.2 é possível observar uma alteração no sinal capacitivo do sistema que ficou com ferroceno por 18 horas, enquanto o sistema que recebeu as moléculas por 1 horas não apresentou um sinal visível.

\subsection{Potencial aplicado - OCP vs $\mathrm{E}_{1 / 2}$}

De acordo com Marques et al., o uso de cargas confinadas redox como ferroceno só apresenta seu sinal máximo em um potencial ou energia capaz de promover o processo de ativação redox da mesma [58]. Para isso, é necessário a aplicação de um processo de voltametria cíclica conforme descrito na seção 2.1.2.3 para o cálculo deste potencial máximo, o potencial de meia onda $\left(\mathrm{E}_{i n}\right)$.

Os eletrodos foram colocados em uma solução eletrolítica PBS $(\mathrm{pH} 7,4)$ e foi aplicada uma velocidade de varredura de $50 \mathrm{mV} / \mathrm{s}$ no intervalo 0,7 a $-0,2 \mathrm{~V}$ 
(vs $\mathrm{Ag} / \mathrm{AgCl}$ ) para um total de 10 ciclos. A Figura 5.3a ilustra os resultados obtidos para o segundo (I) e para o último ciclo (II). O pico superior em $+0,35$ - + 0,40 V corresponde ao pico de oxidação do ferroceno enquanto o pequeno pico inferior representa algum processo de redução da SAM, não sendo atribuído ao FCC pois o mesmo não possui características de reversibilidade [101]. A mudança das amplitudes dos picos do $2^{\circ}$ para o $10^{\circ}$ ciclo se deve principalmente a lenta transferência de elétrons da molécula para a superfície [102, 101] e a formação de espécies carregadas [103].

Como processos irreversíveis não possuem o pico de redução, é necessário o uso da equação 5.1 para o cálculo de um novo potencial de meia onda para estes processos $\left(\mathrm{E}_{1 / 2}\right)[104]$ :

$$
E_{1 / 2}=0,85 . I_{p}
$$

Onde $I_{p}$ é o potencial do pico de oxidação onde a corrente é máxima (descontados os efeitos capacitivos). Pela equação 5.1 foi encontrado um potencial de $0,32 \mathrm{~V}$, pelo menos duas vezes maior que os potenciais de circuito aberto (OCP) obtidos para cada eletrodo individualmente $(90$ - $150 \mathrm{mV})$. Para cada tipo de potencial, os eletrodos foram imersos em diferentes concentrações de NS1 com BSA conforme ilustrado pela Figura 5.3b.

A Figura 5.3b mostra que a aplicação do potencial $\mathrm{E}_{p / 2}$ encontrado gerou um comportamento não linear na resposta do sistema em comparação com os obtidos na aplicação do OCP. As respostas obtidas pelo $\mathrm{E}_{p / 2}$ mostraram um sinal mais intenso em comparação com o de circuito aberto, sendo este atribuído ao bloqueio das cargas acumuladas pela oxidação do FCC na adição de NS1. Por meio desta Figura, o uso do OCP se mostrou mais favorável na otimização e o desenvolvimento de um sistema mais estável.

\subsection{Otimização da proporção entre aptâmero e FCC}

Auletta et al. relata que a proporção entre FCC e outro alcanotiol influencia na interação dos centros eletroativos redox: uma proporção menor de FCC pode gerar centros isolados e sem qualquer ação na SAM; entretanto, uma quantidade 

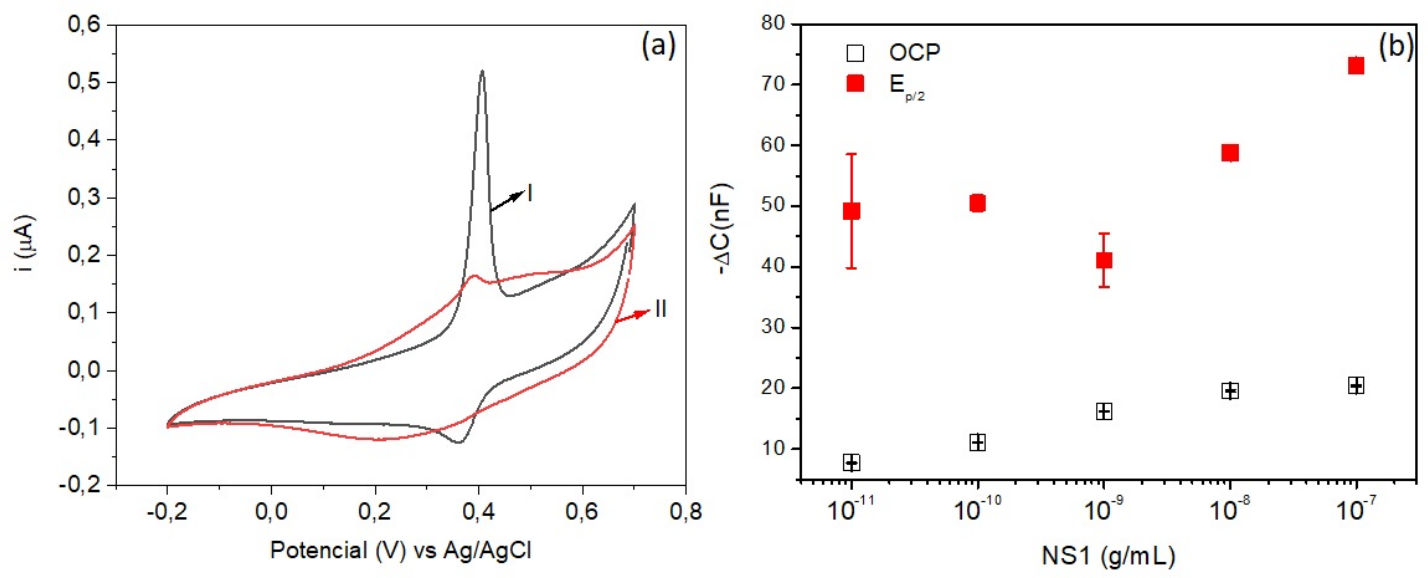

Figura 5.3: Resultados do (a) Voltamograma cíclico da SAM com FCC e aptâmeros, (I) $1^{\circ}$ ciclo, (II) o $10^{\circ}$ ciclo. A taxa de varredura foi de $50 \mathrm{mV} / \mathrm{s}$ em PBS (pH 7,4); (b) Variação na capacitância $(-\Delta C)$ em função das concentraçôes de NS1 para os potenciais de circuito aberto (OCP) (quadrado vermelho sólido) e o de meia onda ( $\left.E_{p / 2}\right)$ (quadrado preto aberto).

maior de FCC pode interferir na oxidação de outras moléculas nas proximidades, afetando a resposta do sistema [102]. Conforme descrito pela seção 4.2, o estudo das proporções entre a co-imobilização de aptâmeros e o espaçador (neste caso, o FCC) é de vital importância na otimização do biossensor. Os eletrodos foram submetidos a diferentes proporções de ambas moléculas: 1:10, 1:50, 1:100, 1:150, 1:200 seguindo o protocolo otimizado da seção 5.1.1. Após o bloqueio da superfície de ouro com BSA, fixou-se os valores de OCP para cada eletrodo e foi adicionado uma concentração de $100 \mathrm{pg} / \mathrm{mL}$ de NS1 com BSA. A Figura 5.4 ilustra as variações em capacitância em função das proporções de aptâmeros e o total de moléculas tioladas presente na SAM.

Na Figura 5.4 é possível observar que para a concentração de NS1 adicionada, a proporção 1:150 apresentou a maior variação de carga com aproximadamente 12 nF e sendo, portanto, a otimização da melhor densidade de aptâmeros e FCC para a montagem da SAM do modo capacitivo.

\subsection{Curva analítica}

Com a otimização dos processos de co-imobilização, do potencial aplicado e da proporção entre aptâmeros e FCC, construiu-se o teste de curva analítica. Neste, 


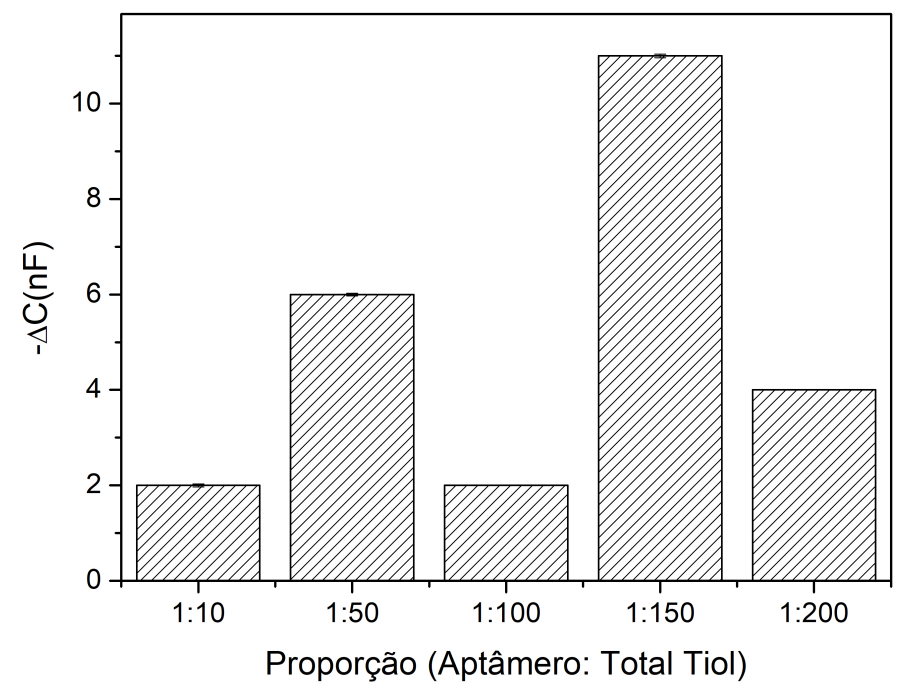

Figura 5.4: Variação de $-\Delta C(n F)$ em função das densidades de superfícies (1:10, 1:50, 1:100, 1:150, e 1:200) para $100 \mathrm{pg} / \mathrm{mL}$ de NS1. As linhas em vermelho no meio das colunas se referem aos erros estatísticos de cada concentração e proporção.

variou-se as concentrações de NS1 de $10 \mathrm{pg}$ a $1 \mu \mathrm{g} / \mathrm{mL}$ para dois meios: o primeiro em tampão PBS $(\mathrm{pH} 7,4)+$ BSA $(0,1 \%)$ e o segundo para soro humano comercial sem diluição. A Figura 5.5 ilustra os resultados obtidos para a NS1 em meio de PBS. A linha pontilhada representa a regressão linear pelas equações 4.1 e 4.2 da seção 4.4 e os resultados obtidos exibem um LoD de 121,8 pg/mL com uma sensibilidade de $3 \mathrm{nF}$ por década, ambos parâmetros obtidos com $\mathrm{R}^{2}=0,96$ (Tabela 5.1). Ao se comparar os LoD obtidos com os apresentados na literatura nos últimos 5 anos (Tabela 4.2) para as técnicas capacitivas, o dispositivo desenvolvido apresentou uma capacidade de detecção maior que os mesmos.

A Figura 5.6 ilustra os resultados obtidos para a NS1 diluída em soro humano comercial. Assim, como na regressão obtida na Figura 4.3, o uso do soro tem como consequência a deposição de outras biomoléculas na SAM, gerando um processo de saturação na última concentração utilizada. Neste sistema, a faixa linear corresponde de $10 \mathrm{pg}$ a $100 \mathrm{ng} / \mathrm{mL}$, gerando um LoD de 6,24 pg/mL e uma sensibilidade de $4 \mathrm{nF}$ por década, com $\mathrm{R}^{2}=0,95$ (Tabela 5.1). A baixa concordância destes valores experimentais com ajuste linear nos levou à busca de outro modelo que pudesse também descrever o sistema. Reich et al. descreve que a equação de 
Tabela 5.1: Parâmetros obtidos pela regressão linear e pelo cálculo do limite de detecção para a $E C E$.

\begin{tabular}{c|cc}
\hline & $\begin{array}{c}\text { Tampão PBS }+ \text { BSA } \\
(0,1 \%)\end{array}$ & $\begin{array}{c}\text { Soro Humano } \\
\text { comercial }\end{array}$ \\
\hline Faixa Linear & $10 \mathrm{pg}-1 \mu \mathrm{g} / \mathrm{mL}$ & $10 \mathrm{pg}-100 \mathrm{ng} / \mathrm{mL}$ \\
$\mathrm{R}^{2}$ & 0,96 & 0,95 \\
LoD & $121,8 \mathrm{pg} / \mathrm{mL}$ & $6,24 \mathrm{pg} / \mathrm{mL}$ \\
Sensibilidade & 3 & 4 \\
(nF por década) & & $5,94.10^{-6 * *}$ \\
RSS* & $4,34.10^{-6 *}$ &
\end{tabular}

* Média do desvio padrão calculado por todos os pontos da curva analítica ** Média do desvio padrão calculado pelos os pontos dentro da faixa linear da curva analítica

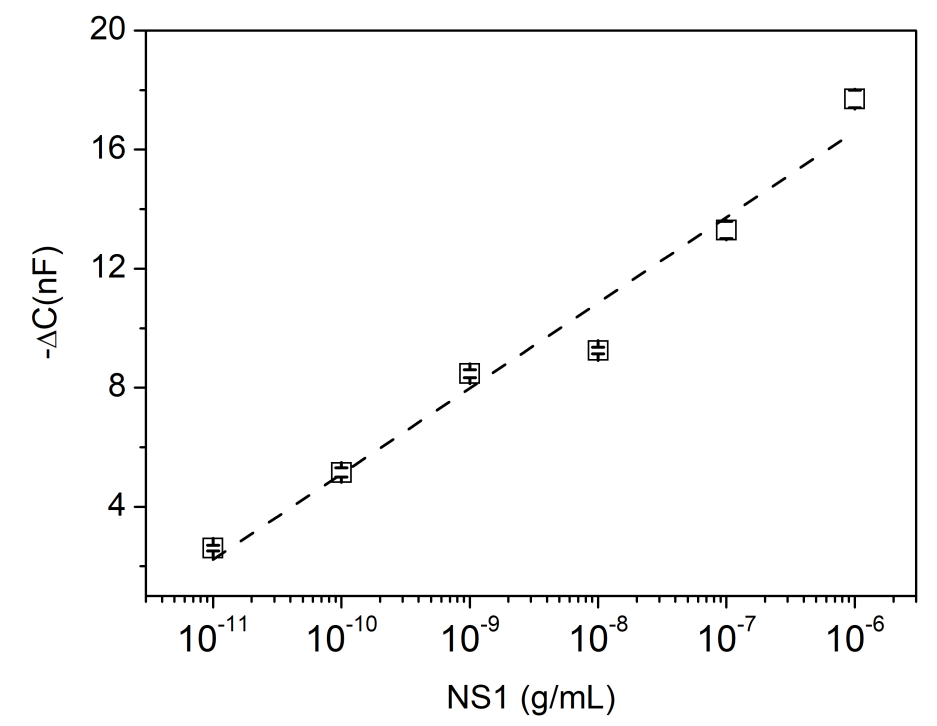

Figura 5.5: Variação da capacitância $-\Delta C(n F)$ em função das concentrações de NS1 em tampão.

Hill (equação 5.2 é capaz de modelar plataformas que utilizam algum componente biológico [105]. A imagem em detalhe dentro da Figura 5.6 mostra este modelamento da equação 5.2 com os dados experimentais $\left(R^{2}=0,99\right)$. 


$$
Y=\Delta C_{\min }+\frac{\left(\Delta C_{m x}-\Delta C_{\min }\right)[X]^{h}}{k^{h}-[X]^{h}}
$$

Sendo $\Delta$ Cmin a mínima capacitância obtida, $\Delta$ Cmáx a máxima capacitância, h o coeficiente de Hill, k a constante de Michaelis e [X] a concentração do analito alvo.

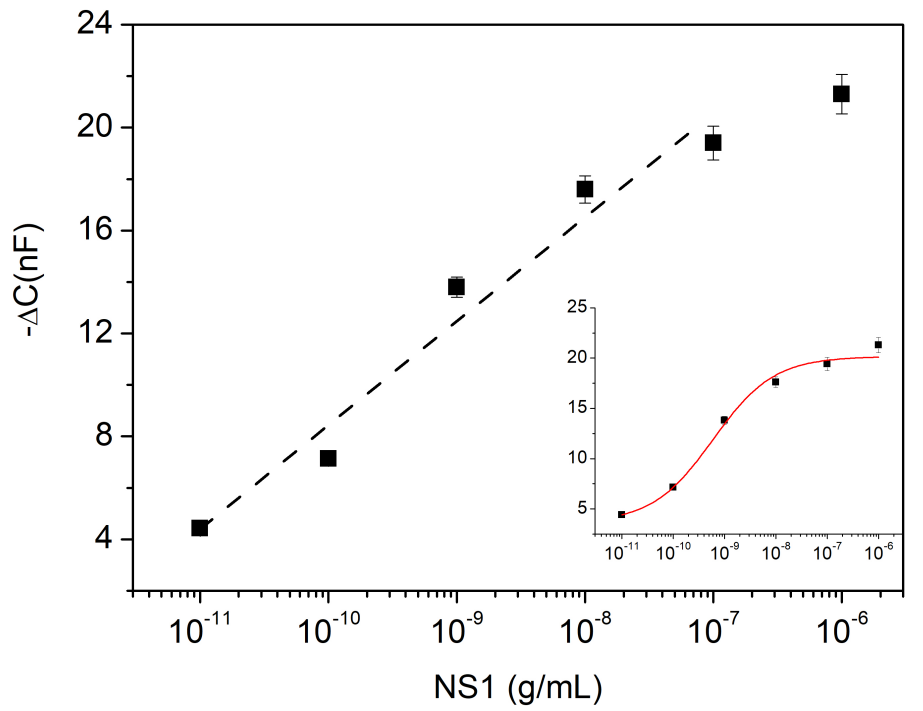

Figura 5.6: Variação da capacitância $-\Delta C(n F)$ em função das concentrações de NS1 em soro comercial humano 100\%. A linha tracejada representa a regressão linear. Em detalhe, a linha continua representa o modelo de Hill para os mesmos dados.

Shraim et al. descreve que esse tipo de função sigmoide é uma possível evidência de cooperatividade de forma que uma molécula de aptâmeros influência na afinidade dos outros aptâmeros ao redor [106]. Ozer et al. também reporta esse tipo de modelo onde, a imobilização de um alvo pode aumentar a densidade de superfície das moléculas alvo até um certo ponto limite que permite que o ligante interaja até de forma inespecífica com outros alvos [107]. Ambos autores descrevem que esse tipo de modelo ainda não traz informações como o LoD e sensibilidade, necessitando de mais estudos para comprovar tais aspectos. 


\subsection{Controle Negativo}

Assim como na seção 4.5, o teste de controle negativo foi realizado para o modelo capacitivo. Para este teste, foi utilizado novamente a proteína E. Os eletrodos modificados com aptâmeros e FCC foram expostos a uma concentração de $1 \mathrm{ng} / \mathrm{mL}$ das proteínas NS1 e E diluídas em Soro comercial por 30 minutos. A Figura 5.7 ilustra os resultados obtidos para cada tipo de alvo.

É possível observar que a NS1 apresenta a maior variação de capacitância (aprox. $14 \mathrm{nF}$ ) em comparação com a proteína $\mathrm{E}(8 \mathrm{nF})$, gerando uma mudança significativa entre ambos sinais $(6 \mathrm{nF})$. Estes resultados corroboram com os apresentados na figura 4.4, na qual o aptâmero utilizado possui um alto grau de especificidade.

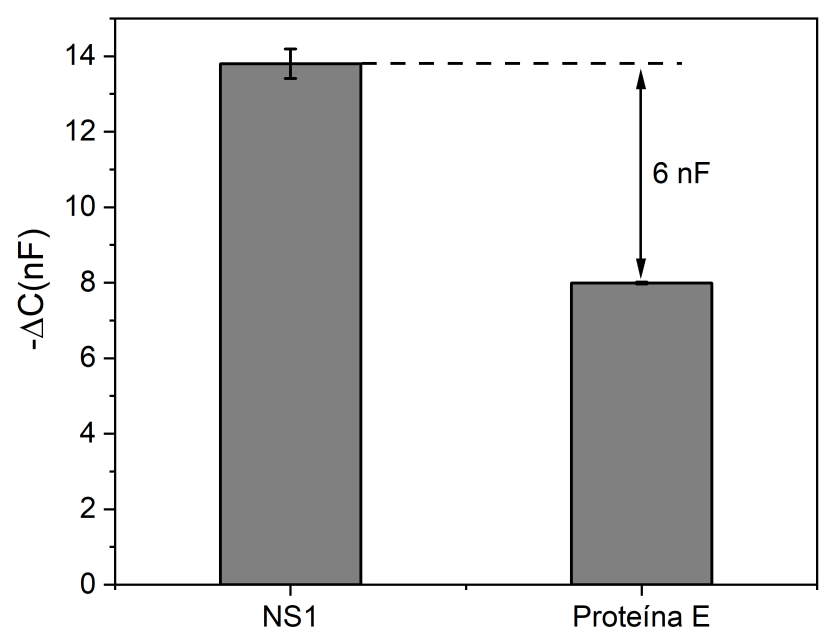

Figura 5.7: Controle negativo. Variação do $-\Delta C(n F)$ em função da proteína alvo: NS1 e a proteína $E$ em uma concentração de $1 \mathrm{ng} / \mathrm{mL}$ diluídas em soro.

\subsection{Conclusões parciais}

A caracterização de aptassensores pela espectroscopia de capacitância eletroquímica mostrou que uso do FCC na funcionalização da SAM possui forças de interação S-H maiores que as de adsorção. Ao se estabilizar, o ferroceno gera 
um acúmulo de cargas que vai decaindo conforme ocorre a interação da NS1 com o aptâmero.

Por ser um sistema mais sensível às alterações de superfície, a ECE mostrou uma estabilização melhor com seu próprio potencial (OCP) em comparação com o potencial de meia onda $\left(\mathrm{E}_{p / 2}\right)$ obtido pela voltametria cíclica. Dentre as proporções entre aptâmeros e FCC, o valor 1:150 mostrou-se como a melhor distribuição de ambas moléculas e consequentemente o maior sinal capacitivo.

Com todas as otimizações anteriores, a plataforma apresentou o melhor limite de deteç̧ão, 121,8 e 6,62 pg/mL (PBS e Soro humano comercial, respectivamente), em comparação com a literatura. Esses valores obtidos estão abaixo da faixa clínica $\left(0,04\right.$ a $2 \mu \mathrm{g} / \mathrm{mL}$ para $1^{a}$ infecção e 0,01 a $2 \mu \mathrm{g} / \mathrm{mL}$ para $2^{a}$ infecção), ou seja, é possível detectar a NS1 com a ECE também em seus estágios iniciais. Como no sistema impedimétrico, o modelo capacitivo estudado mostrou um alto grau de seletividade ao ser submetido com a proteína E, também produzida pelo vírus da Dengue. 


\section{Capítulo}

\section{CONCLUSÕES GERAIS}

O presente trabalho buscou desenvolver um biossensor label-free com aptâmeros para detectar a proteína NS1, expressa na infecção por Dengue. Aptâmeros são cadeia de DNA sintéticas produzidas para se ligar com proteínas com grande afinidade e especificidade. A caracterização foi realizada através das técnicas de voltametria cíclica, microscopia de força atômica, espectroscopia de impedância eletroquímica e pela espectroscopia de capacitância eletroquímica.

A plataforma foi otimizada primeiramente nos protocolos de imobilização, incluindo a limpeza do eletrodo, preparo e co-imobilização do aptâmero com o espaçador, tampões, estabilidade da monocamada e a quantificação da densidade superficial. A área efetiva do eletrodo de ouro foi estimada pela limpeza eletroquímica e foram obtidos valores entre 1,6 e 1,8, representando uma superfície policristanila estável e reprodutível. Um tempo maior (40 minutos) para o enovelamento do aptâmero combinado com tampão SELEX, se mostrou a melhor configuração para a formação da SAM, do controle da densidade de superfície e da reprodutibilidade.

O uso da proteína de soro bovino (BSA) em um tampão PBS em pH 7,4 se mostrou de extrema importância na estabilização da NS1 e para o bloqueio da SAM, de forma a diminuir a incidências das interações não específicas. Na configuração do equipamento, o uso do potencial de circuito aberto (OCP) se mostrou necessário para a amplificação do sinal. A melhor densidade de superfície (1:150) foi obtida pela espectroscopia de impedância eletroquímica, bem como todo protocolo de otimização de imobilização em conjunto com a voltametria cíclica.

$\mathrm{Na}$ caracterização pela microscopia de força atômica foi possível observar a 
mudança da rugosidade da superfície na adição do espaçador, na formação da SAM e da adição da proteína alvo. Com todas essas otimizações, construiu-se uma curva de calibração pelo método impedimétrico, onde o limite de detecção foi de 1,29, 0,12 e $1,22 \mathrm{pg} / \mathrm{mL}$ para os meios PBS, PBS + soro humano comercial (50\%) e soro humano $100 \%$, respectivamente. Estes valores foram abaixo dos encontrados na literatura, o que torna este dispositivo apto para detecção de Dengue em seus estágios iniciais. O controle negativo mostrou que a plataforma é seletiva na detecção da NS1.

O desenvolvimento de uma plataforma capacitiva foi possível através da adição do ferroceno. A otimização desta técnica engloba o tipo de potencial aplicado e a densidade de superfície. Neste caso, o potencial de circuito aberto (OCP) provou ser capaz de manter a estabilidade da SAM. O estudo desta distribuição de cargas demostrou uma densidade de superfície entre aptâmeros e FCC ideal (1:150).

Com as otimizações obtidas para o modelo capacitivo, construiu-se uma curva analítica com os limites de detecções de 121,8 e 6,24 pg/mL para os meios de PBS e soro humano comercial sem diluição. Em comparação com os valores obtidos na literatura, o aptassensor capacitivo desenvolvido neste trabalho possui o menor limite de detecção, podendo detectar a NS1 de forma seletiva nos estágios iniciais, como no modelo impedimétrico.

O uso de aptâmeros no desenvolvimento de biossensores aliados às técnicas eletroquímicas apresentaram resultados promissores na detecção da proteína NS1 da Dengue, bem como baixos limites de detecção. Os resultados obtidos neste trabalho permitem a adaptação do dispositivo para modelos miniaturizados "point-in-care". 


\section{REFERÊNCIAS $^{1}$}

[1] HOLBROOK, M. Historical perspectives on flavivirus research. Viruses, v. 9, n. 5, p. 97, 4 2017. ISSN 1999-4915.

[2] INFORME epidemiológico do SUS. v. 8, p. 29, 1999.

[3] BARRETO, M. L.; TEIXEIRA, M. G. Dengue no brasil: situação epidemiológica e contribuições para uma agenda de pesquisa. Estudos Avançados, v. 22, n. 64, p. 53-72, 12 2008. ISSN 0103-4014.

[4] CAVAlCANTI, L. P. d. G. et al. Surveillance of deaths caused by arboviruses in brazil: from dengue to chikungunya. Memórias do Instituto Oswaldo Cruz, v. 112, n. 8, p. 583-585, 8 2017. ISSN 0074-0276.

[5] ORGANIZATION, W. H. Global strategy for dengue prevention and control, 2012-2020. Geneva, Switzerland: World Health Organization, 2012. OCLC: 810089448. ISBN 978-92-4-150403-4. Disponível em: $<$ http://apps.who.int/iris/bitstream/10665/75303/1/9789241504034_eng.pdf $>$.

[6] STANAWAY, J. D. et al. The global burden of dengue: an analysis from the global burden of disease study 2013. The Lancet. Infectious Diseases, v. 16, n. 6, p. 712-723, 2016. ISSN 1474-4457. PMID: 26874619 PMCID: PMC5012511.

[7] GUZMAN, M. G. et al. Dengue: a continuing global threat. Nature Reviews Microbiology, v. 8, n. 12supp, p. S7-S16, 12 2010. ISSN 1740-1526, 1740-1534.

[8] HASAN, S. et al. Dengue virus: A global human threat: Review of literature. Journal of International Society of Preventive 86 Community Dentistry, v. 6, n. 1, p. 1-6, 2016. ISSN 2231-0762. PMID: 27011925 PMCID: PMC4784057.

\footnotetext{
${ }^{1}$ De acordo com a Associação Brasileira de Normas Técnicas. NBR 6023.
} 
[9] GURUGAMA, P. et al. Dengue viral infections. Indian Journal of Dermatology, v. 55, n. 1, p. 68-78, 2010. ISSN 0019-5154. PMID: 20418983 PMCID: PMC2856379.

[10] NARAYANAN, M. et al. Dengue fever epidemic in chennai a study of clinical profile and outcome. Indian Pediatrics, v. 39, n. 11, p. 1027-1033, 11 2002. ISSN 0019-6061. PMID: 12466573.

[11] ALCON, S. et al. Enzyme-linked immunosorbent assay specific to dengue virus type 1 nonstructural protein ns1 reveals circulation of the antigen in the blood during the acute phase of disease in patients experiencing primary or secondary infections. Journal of Clinical Microbiology, v. 40, n. 2, p. 376-381, 2 2002. ISSN 0095-1137.

[12] PARKASH, O.; SHUEB, R. Diagnosis of dengue infection using conventional and biosensor based techniques. Viruses, v. 7, n. 10, p. 5410-5427, 10 2015. ISSN 1999-4915.

[13] EDEling, M. A.; DIAMOND, M. S.; FREMONT, D. H. Structural basis of flavivirus ns1 assembly and antibody recognition. Proceedings of the National Academy of Sciences, v. 111, n. 11, p. 4285-4290, 3 2014. ISSN 0027-8424, 1091-6490.

[14] CHAMBERS, T. J. et al. Flavivirus genome organization, expression, and replication. Annual Review of Microbiology, v. 44, p. 649-688, 1990. ISSN 0066-4227. PMID: 2174669.

[15] MACKENZIE, J. M.; JONES, M. K.; YOUNG, P. R. Immunolocalization of the dengue virus nonstructural glycoprotein ns1 suggests a role in viral rna replication. Virology, v. 220, n. 1, p. 232-240, 6 1996. ISSN 0042-6822. PMID: 8659120.

[16] FIGUEIREDO, A. et al. Electrical detection of dengue biomarker using egg yolk immunoglobulin as the biological recognition element. Scientific Reports, v. 5, n. 1, 7 2015. ISSN 2045-2322. [Online; accessed 2018-01-15]. Disponível em: $<$ http://www.nature.com/articles/srep07865>. 
[17] HALSTEAD, S. B. Pathogenesis of dengue: Dawn of a new era. F1000Research, v. 4, p. 1353, 11 2015. ISSN 2046-1402.

[18] HALSTEAD, S. B. Dengue. Lancet (London, England), v. 371, n. 9599, p. $1644-52,2008$.

[19] HALSTEAD, S. B. Pathogenesis of dengue: challenges to molecular biology. v. 239 , p. 7 .

[20] BLACKSELL, S. D. et al. Comparison of seven commercial antigen and antibody enzyme-linked immunosorbent assays for detection of acute dengue infection. Clinical and Vaccine Immunology, v. 19, n. 5, p. 804-810, 5 2012. ISSN 1556-6811, 1556-679X. PMID: 22441389.

[21] RATHAKRISHNAN, A.; SEKARAN, S. D. New development in the diagnosis of dengue infections. Expert Opinion on Medical Diagnostics, v. 7, n. 1, p. 99-112, 1 2013. ISSN 1753-0059. PMID: 23530846.

[22] KONG, Y. Y. et al. Rapid detection, serotyping and quantitation of dengue viruses by taqman real-time one-step rt-pcr. Journal of Virological Methods, v. 138, n. 1-2, p. 123-130, 12 2006. ISSN 0166-0934. PMID: 17000012.

[23] NUNES, M. R. T. et al. Evaluation of an immunoglobulin m-specific capture enzyme-linked immunosorbent assay for rapid diagnosis of dengue infection. Journal of Virological Methods, v. 171, n. 1, p. 13-20, 1 2011. ISSN 0166-0934.

[24] PAL, S. et al. Multicountry prospective clinical evaluation of two enzyme-linked immunosorbent assays and two rapid diagnostic tests for diagnosing dengue fever. Journal of Clinical Microbiology, v. 53, n. 4, p. 1092-1102, 4 2015. ISSN 0095-1137, 1098-660X. PMID: 25588659.

[25] PAL, S. et al. Evaluation of dengue ns1 antigen rapid tests and elisa kits using clinical samples. PLOS ONE, v. 9, n. 11, p. e113411, 11 2014. ISSN 1932-6203.

[26] WANG, S. M.; SEKARAN, S. D. Evaluation of a commercial sd dengue virus ns1 antigen capture enzyme-linked immunosorbent assay kit for early diagnosis of 
dengue virus infection. Journal of Clinical Microbiology, v. 48, n. 8, p. 2793-2797, 8 2010. ISSN 0095-1137, 1098-660X. PMID: 20573879.

[27] HERMANN, L. L. et al. Evaluation of a dengue ns1 antigen detection assay sensitivity and specificity for the diagnosis of acute dengue virus infection. PLOS Neglected Tropical Diseases, v. 8, n. 10, p. e3193, 10 2014. ISSN 1935-2735.

[28] V., H. U. P. Advances in biosensors: Principle, architecture and applications. J Appl Biomed, v. 12, n. 1, p. 1-15, 2014.

[29] CAVAlCANTI, I. T. et al. A label-free immunosensor based on recordable compact disk chip for early diagnostic of the dengue virus infection. Biochemical Engineering Journal, v. 67, p. 225-230, 8 2012. ISSN 1369-703X.

[30] DIAS, A. C. M. S. et al. A sensor tip based on carbon nanotube-ink printed electrode for the dengue virus ns1 protein. Biosensors and Bioelectronics, v. 44, p. 216-221, 6 2013. ISSN 0956-5663.

[31] WU, T.-Z. et al. Piezoelectric immunochip for the detection of dengue fever in viremia phase. Biosensors and Bioelectronics, v. 21, n. 5, p. 689-695, 112005. ISSN 0956-5663.

[32] KASSIM, F. M. et al. Use of dengue ns1 antigen for early diagnosis of dengue virus infection. The Southeast Asian Journal of Tropical Medicine and Public Health, v. 42, n. 3, p. 562-569, 5 2011. ISSN 0125-1562. PMID: 21706934.

[33] TELES, F. S. R. R. Biosensors and rapid diagnostic tests on the frontier between analytical and clinical chemistry for biomolecular diagnosis of dengue disease: a review. Analytica Chimica Acta, v. 687, n. 1, p. 28-42, 2 2011. ISSN 1873-4324. PMID: 21241843.

[34] WONG, W. R. et al. Serological diagnosis of dengue infection in blood plasma using long-range surface plasmon waveguides. Analytical Chemistry, v. 86, n. 3, p. 1735-1743, 2 2014. ISSN 0003-2700.

[35] BHALLA, N. et al. Introduction to biosensors. Essays In Biochemistry, v. 60, n. 1, p. 1-8, 6 2016. ISSN 0071-1365, 1744-1358. 
[36] LELAND C. Clark Jr. (1918-2005) - ScienceDirect. [Online; accessed 2018-01-30]. Disponível em: <https://www.sciencedirect.com/science/article/pii/S0956566305004094?via\%3Dihub>.

[37] SCHELLER, F. W. et al. Research and development in biosensors. Current Opinion in Biotechnology, v. 12, n. 1, p. 35-40, 2 2001. ISSN 09581669.

[38] SCHELlER, F. et al. Biosensors: Fundamentals, applications and trends. Sensors and Actuators B: Chemical, v. 4, n. 1-2, p. 197-206, 5 1991. ISSN 09254005.

[39] FANG, A.; NG, H. T.; LI, S. F. Y. A high-performance glucose biosensor based on monomolecular layer of glucose oxidase covalently immobilised on indium?tin oxide surface. Biosensors and Bioelectronics, v. 19, n. 1, p. 43-49, 10 2003. ISSN 09565663.

[40] CHEN, C. et al. Recent advances in electrochemical glucose biosensors: a review. $R S C$ Advances, v. 3, n. 14, p. 4473, 2013. ISSN 2046-2069.

[41] WANG, P.; LIU, Q. (Ed.). Cell-based biosensors: principles and applications. Norwood, MA: Artech House, 2009. (Engineering in science \& biology). OCLC: ocn430839125. ISBN 978-1-59693-439-9.

[42] MEHROTRA, P. Biosensors and their applications: A review. Journal of Oral Biology and Craniofacial Research, v. 6, n. 2, p. 153-159, 5 2016. ISSN 22124268.

[43] ALHADRAMI, H. A. Biosensors: Classifications, medical applications, and future prospective: Classification, applications, and prospects of biosensors. Biotechnology and Applied Biochemistry, v. 65, n. 3, p. 497-508, 5 2018. ISSN 08854513.

[44] CECCHETTO, J. et al. An impedimetric biosensor to test neat serum for dengue diagnosis. Sensors and Actuators B: Chemical, v. 213, p. 150-154, 72015. ISSN 09254005.

[45] JOLLY, P. et al. Highly sensitive dual mode electrochemical platform for microrna detection. Scientific Reports, v. 6, n. 1, 12 
2016. ISSN 2045-2322. [Online; accessed 2018-01-31]. Disponível em: $<$ http://www.nature.com/articles/srep36719>.

[46] MOHAnty, S.; KOUGIAnOS, E. Biosensors: a tutorial review. IEEE Potentials, v. 25, n. 2, p. 35-40, 3 2006. ISSN 0278-6648.

[47] ATKINS, P.; JONES, L. Princípios de química. 5. ed. [S.l.]: bookman. ISBN 978-1-4292-1955-6.

[48] TICIANELli, E. A.; GONZALEZ, E. R. Eletroquímica. 2. ed. Edusp: [s.n.]. ISBN 85-314-0424-X.

[49] BOCKIS, J. O.; REDDY, A. K. N.; GAMBOA-ALDECO, M. Modern Electrochemistry 2A. [S.l.]: Kluwer Academic Publishers. ISBN 0-306-46166-8.

[50] THEVENOT, D. R. et al. Electrochemical biosensors: recommended de?nitions and classi?cation. p. 11, 2001.

[51] BARD, A. J.; FAULKNER, L. R. Electrochemical Methods: Fudamentals and applications. $2^{\circ}$. ed. [S.1.]: John Wiley \& Sons, INC.

[52] KEIGHLEY, S. D. et al. Optimization of dna immobilization on gold electrodes for label-free detection by electrochemical impedance spectroscopy. Biosensors and Bioelectronics, v. 23, n. 8, p. 1291-1297, 3 2008. ISSN 09565663.

[53] ROCHA, P. R. F. et al. Electrochemical noise and impedance of au electrode/electrolyte interfaces enabling extracellular detection of glioma cell populations. Scientific Reports, v. 6, p. 34843, 10 2016. ISSN 2045-2322.

[54] GóES, M. S. et al. A dielectric model of self-assembled monolayer interfaces by capacitive spectroscopy. Langmuir, v. 28, n. 25, p. 9689-9699, 6 2012. ISSN 0743-7463, 1520-5827.

[55] YUAN, X.-Z. et al. Electrochemical Impedance Spectroscopy in PEM Fuel Cells. London: Springer London, 2010. DOI: 10.1007/978-1-84882-846-9. ISBN 978-1-84882-845-2. Disponível em: $<$ http://link.springer.com/10.1007/978-1-84882-846-9>. 
[56] FERNANDES, F. C. B. et al. Label free redox capacitive biosensing. Biosensors and Bioelectronics, v. 50, p. 437-440, 12 2013. ISSN 09565663.

[57] SANTOS, A. Fundamentals and applications of impedimetric and redox capacitive biosensors. Journal of Analytical $\&$ Bioanalytical Techniques, S7, n. 012, 2014. ISSN 21559872. [Online; accessed 2018-07-06].

[58] MARQUES, S. M. U. et al. Sensitive label-free electron chemical capacitive signal transduction for d-dimer electroanalysis. Electrochimica Acta, p. 946-952, 11 2015. ISSN 0013-4686.

[59] FONSECA, I.; PROENçA, L.; CAPELO, S. A voltametria cíclica e de varrimento linear unidirecional: suas potencialidades na caraterização de processos de corrosão. Corrosão e Protecção de Materiais, v. 34, n. 1, p. 12-21, 6 2015. ISSN 0870-1164.

[60] SILVA, d. A. C. N. Estudo de superfícies inteligentes para desenvolvimento de nanobiossensores, dissertação (mestrado em materiais funcionais e polímeros de fontes renováveis). 4 2014. [Online; accessed 2018-12-02]. Disponível em: $<$ https://repositorio.ufscar.br/handle/ufscar/1179>.

[61] FERREIRA, A. A. P.; YAMANAKA, H. Microscopia de força atômica aplicada em imunoensaios. Química Nova, v. 29, n. 1, p. 137-142, 2 2006. ISSN 0100-4042.

[62] OLIVEIRA, R. R. L. D. et al. Measurement of the nanoscale roughness by atomic force microscopy: Basic principles and applications. Atomic Force Microscopy - Imaging, Measuring and Manipulating Surfaces at the Atomic Scale, 3 2012. [Online; accessed 2018-12-02].

[63] HAMMOND, J. L. et al. Electrochemical biosensors and nanobiosensors. Essays In Biochemistry, v. 60, n. 1, p. 69-80, 6 2016. ISSN 0071-1365, 1744-1358.

[64] SONG, S. et al. Aptamer-based biosensors. TrAC Trends in Analytical Chemistry, v. 27, n. 2, p. 108-117, 2 2008. ISSN 01659936. 
[65] TOMBELli, S.; MINUNNI, M.; MASCINI, M. Aptamers-based assays for diagnostics, environmental and food analysis. Biomolecular Engineering, v. 24, n. 2, p. 191-200, 6 2007. ISSN 1389-0344. PMID: 17434340.

[66] JOLLY, P.; ESTRELA, P.; LADOMERY, M. Oligonucleotide-based systems: Dna, micrornas, dna/rna aptamers. Essays In Biochemistry, v. 60, n. 1, p. 27-35, 6 2016. ISSN 0071-1365, 1744-1358.

[67] SANTOS-ALVAREZ, N. de-los et al. Modified-rna aptamer-based sensor for competitive impedimetric assay of neomycin b. Journal of the American Chemical Society, v. 129, n. 13, p. 3808-3809, 4 2007. ISSN 0002-7863. PMID: 17355135.

[68] JOLLY, P.; FORMISANO, N.; ESTRELA, P. Dna aptamer-based detection of prostate cancer. Chemical Papers, v. 69, n. 1, 1 2015. ISSN 1336-9075. [Online; accessed 2018-01-18].

[69] LEE, K. H.; ZENG, H. Aptamer-based elisa assay for highly specific and sensitive detection of zika ns1 protein. Analytical Chemistry, v. 89, n. 23, p. 12743-12748, 12 2017. ISSN 0003-2700, 1520-6882.

[70] BENITES, T. A. et al. Effects of surface roughness on properties of passivation of self-assembled organic monolayers. Química Nova, 2014. ISSN 0100-4042. [Online; accessed 2018-05-23]. Disponível em: <http://www.gnresearch.org/doi/10.5935/0100-4042.20140241>.

[71] KLEINJUNG, F. et al. High-affinity rna as a recognition element in a biosensor. Analytical Chemistry, v. 70, n. 2, p. 328-331, 1998.

[72] SANTOS-ÁLVAREZ, N. de-los et al. Aptamers as recognition elements for label-free analytical devices. TrAC Trends in Analytical Chemistry, v. 27, n. 5, p. 437-446, 5 2008. ISSN 01659936.

[73] SYAHIR, A. et al. Label and label-free detection techniques for protein microarrays. Microarrays, v. 4, n. 2, p. 228-244, 4 2015. ISSN 2076-3905. PMID: 27600222 PMCID: PMC4996399. 
[74] JARZABEK, G.; BORKOWSKA, Z. On the real surface area of smooth solid electrodes. Electrochimica Acta, v. 42, n. 19, p. 2915 - 2918, 1997. ISSN 0013-4686.

[75] CARVAlhal, R. F.; FREIRE, R. S.; KUBOTA, L. T. Polycrystalline gold electrodes: A comparative study of pretreatment procedures used for cleaning and thiol self-assembly monolayer formation. Electroanalysis, v. 17, n. 14, p. 1251-1259, 2004. ISSN 1521-4109.

[76] ULMAN, A. Formation and structure of self-assembled monolayers. Chemical Reviews, v. 96, n. 4, p. 1533-1554, 1 1996. ISSN 0009-2665, 1520-6890.

[77] O'BRIEN, E. P.; BROOKS, B. R.; THIRUMALAI, D. Effects of ph on proteins: Predictions for ensemble and single molecule pulling experiments. Journal of the American Chemical Society, v. 134, n. 2, p. 979-987, 1 2012. ISSN 0002-7863. PMID: 22148729 PMCID: PMC3262061.

[78] S., H. B. Y. A. On the ph dependence of protein stability. Journal of Molecular Biology, v. 231, n. 2, p. 459-474, 5 1993. ISSN 0022-2836.

[79] J. MCCAMMON J. A., G. M. K. A. Prediction of ph-dependent properties of proteins. Journal of Molecular Biology, v. 238, n. 3, p. 415-436, 5 1994. ISSN 0022-2836.

[80] CHURA-CHAMBI, R. M. et al. Protein refolding based on high hydrostatic pressure and alkaline ph: Application on a recombinant dengue virus ns1 protein. PLoS ONE, v. 14, n. 1, 1 2019. ISSN 1932-6203. PMID: 30682103 PMCID: PMC6347194. Disponível em: <https://www.ncbi.nlm.nih.gov/pmc/articles/PMC6347194/>.

[81] PIERANGELI, M. A. P. et al. Efeito da força iônica da solução de equilíbrio sobre a adsorção/dessorção de chumbo em latossolos brasileiros. Pesquisa Agropecuária Brasileira, v. 36, n. 8, p. 1077-1084, 8 2001. ISSN 0100-204X.

[82] STEEL, A. B.; HERNE, T. M.; TARLOV, M. J. Electrostatic interactions of redox cations with surface-immobilized and solution dna. Bioconjugate Chemistry, v. 10, n. 3, p. 419-423, 5 1999. ISSN 1043-1802. 
[83] CHEN, H.-R.; LAI, Y.-C.; YEH, T.-M. Dengue virus non-structural protein 1: a pathogenic factor, therapeutic target, and vaccine candidate. Journal of Biomedical Science, v. 25, n. 1, 122018. ISSN 1423-0127. [Online; accessed 2018-07-04]. Disponível em: $<$ https://jbiomedsci.biomedcentral.com/articles/10.1186/s12929-018-0462-0>.

[84] MULLER, D. A. et al. Structure of the dengue virus glycoprotein non-structural protein 1 by electron microscopy and single-particle analysis. Journal of General Virology, v. 93, n. 4, p. 771-779, 4 2012. ISSN 0022-1317, 1465-2099.

[85] SIRIWARDANA, K. et al. Studying the effects of cysteine residues on protein interactions with silver nanoparticles. The journal of physical chemistry. C, Nanomaterials and interfaces, v. 119, n. 5, p. 2910-2916, 2015. ISSN 1932-7447. PMID: 26207157 PMCID: PMC4507288.

[86] SHRIVASTAVA, A.; GUPTA, V. B. Methods for the determination of limit of detection and limit of quantitation of the analytical methods. Chronicles of Young Scientists, v. 2, n. 1, p. 21, 1 2011. ISSN 2229-5186.

[87] BEYKAL, B. et al. Influence of surface charge on the rate, extent, and structure of adsorbed bovine serum albumin to gold electrodes. Journal of Colloid and Interface Science, v. 460, p. 321-328, 12 2015. ISSN 0021-9797.

[88] ARMBRUSTER, D. A.; PRY, T. Limit of blank, limit of detection and limit of quantitation. The Clinical Biochemist Reviews, v. 29, n. Suppl 1, p. S49-S52, 8 2008. ISSN 0159-8090. PMID: 18852857 PMCID: PMC2556583.

[89] KANG, Y. et al. Effect of disulfide bond reduction on bovine serum albumin-stabilized emulsion gel formed by microbial transglutaminase. Journal of Food Science, v. 68, n. 7, p. 2215-2220, 9 2003. ISSN 0022-1147.

[90] LIM, J. M. et al. An electrochemical peptide sensor for detection of dengue fever biomarker ns1. Analytica Chimica Acta, v. 1026, p. 109-116, 10 2018. ISSN 0003-2670. 
[91] WASIK, D.; MULCHANDANI, A.; YATES, M. V. Salivary detection of dengue virus ns1 protein with a label-free immunosensor for early dengue diagnosis. Sensors, v. 18, n. 8, p. 2641, 82018.

[92] SANTOS, A.; BUENO, P. R.; DAVIS, J. J. A dual marker label free electrochemical assay for flavivirus dengue diagnosis. Biosensors and Bioelectronics, v. 100, p. 519-525, 2 2018. ISSN 09565663.

[93] CECCHETTO, J. et al. The capacitive sensing of ns1 flavivirus biomarker. Biosensors and Bioelectronics, v. 87, p. 949-956, 1 2017. ISSN 09565663.

[94] SINAWANG, P. D. et al. Electrochemical lateral flow immunosensor for detection and quantification of dengue ns1 protein. Biosensors and Bioelectronics, v. 77, p. 400-408, 3 2016. ISSN 0956-5663.

[95] H. PALOMARES-JEREZ F., V. J. N. The membrane-active regions of the dengue virus proteins c and e. Biochimica et Biophysica Acta (BBA) Biomembranes, v. 1808, n. 10, p. 2390-2402, 10 2011. ISSN 0005-2736.

[96] ROWE, G. K.; CREAGER, S. E. Redox and ion-pairing thermodynamics in self-assembled monolayers. Langmuir, v. 7, n. 10, p. 2307-2312, 10 1991. ISSN 0743-7463.

[97] FEITOZA, B. R. S. Ciclometalados de paládio(ii) contendo ligantes n- e p- doadores bidentados: síntese, caracterização e estudos biológicos.dissertação de mestrado. 2 2019. [Online; accessed 2019-11-13]. Disponível em: $<$ https://repositorio.unesp.br/handle/11449/181136>.

[98] CASERO, E. et al. Electrochemically triggered reaction of a surface-confined reagent: Mechanistic and eqcm characterization of redox-active self-assembling monolayers derived from 5,5?-dithiobis(2-nitrobenzoic acid) and related materials. Langmuir, v. 15, n. 1, p. 127-134, 1 1999. ISSN 0743-7463.

[99] MARCHANTE, E. et al. An electrically driven and readable molecular monolayer switch based on a solid electrolyte. 10 2015. [Online; accessed 2019-11-13]. Disponível em: $<$ https://zenodo.org/record/3504527\#.Xcyd01dKjIU>. 
[100] RIVERA, I. M.; CABRERA, C. R. Mass measurements of ferrocene adsorption at gold films with the electrochemical quartz crystal microbalance. Journal of The Electrochemical Society, v. 140, n. 3, p. L36-L38, 1 1993. ISSN 0013-4651, 1945-7111.

[101] KARADAG, M. et al. Modified gold surfaces by 6-(ferrocenyl)hexanethiol/dendrimer/gold nanoparticles as a platform for the mediated biosensing applications. Materials science $\&$ engineering. $C$, Materials for biological applications, v. 33, n. 2, p. 634-640, 2013.

[102] AulettA, T.; VEGGEL, F. C. J. M. van; Reinhoudt, D. N. Self-assembled monolayers on gold of ferrocene-terminated thiols and hydroxyalkanethiols. Langmuir, v. 18, n. 4, p. 1288-1293, 2 2002. ISSN 0743-7463, $1520-5827$.

[103] SANDFORD, C. et al. A synthetic chemist's guide to electroanalytical tools for studying reaction mechanisms. Chemical Science, v. 10, n. 26, p. 6404-6422, 2019.

[104] FRY, A. J. Synthetic Organic Electrochemistry. [S.1.]: John Wiley \& Sons, 1989. ISBN 978-0-471-63396-9.

[105] REICH, P. et al. Development of an impedimetric aptasensor for the detection of staphylococcus aureus. International Journal of Molecular Sciences, v. 18, n. 11, 11 2017. ISSN 1422-0067. PMID: 29160851 PMCID: PMC5713450.

[106] SHRAIM, A. S. et al. Developing and characterization of chemically modified rna aptamers for targeting wild type and mutated c-kit receptor tyrosine kinases. Journal of Medicinal Chemistry, p. acs.jmedchem.9b00868, 8 2019. ISSN 0022-2623, 1520-4804.

[107] OZER, A. et al. Density-dependent cooperative non-specific binding in solid-phase selex affinity selection. Nucleic Acids Research, v. 41, n. 14, p. 7167-7175, 8 2013. ISSN 1362-4962. PMID: 23737446 PMCID: PMC3737557. 


\section{APÊNDICE}

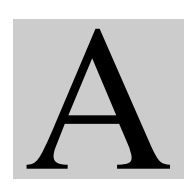

\section{Microscopia DE ForÇA ATÔMICA}

A Tabela A.1 mostra os resultados dos outros parâmetros de rugosidade obtidos pela técnica de microscopia de força atômica. Em todos estes parâmetros é possível constatar as mudanças causadas pela adição da SAM e da NS1 na superfície do eletrodo.

Tabela A.1: Resultados dos parâmetros obtidos pela AFM para cada etapa desenvolvida no eletrodo de ouro

\begin{tabular}{c|ccccc}
\hline & $\begin{array}{c}\text { Resolução } \\
\left(\mu \mathrm{m}^{2}\right)\end{array}$ & $\begin{array}{c}\text { Rugosidade } \\
\text { máxima } \\
\left(R_{y}\right)(\mathrm{nm})\end{array}$ & $\begin{array}{c}\text { Profundidade } \\
\text { máxima }\end{array}$ & $\begin{array}{c}\text { Rugosidade } \\
\text { total }\end{array}$ & $\begin{array}{c}\text { Rugosidade } \\
\text { quadrática média }\end{array}$ \\
\hline Limpo & 2,5 & 58,37 & 68,79 & 127,16 & 11,76 \\
MCH & 2,5 & 30,61 & 26,50 & 57,11 & 6,14 \\
Limpo & 1,0 & 50,07 & 63,11 & 113,18 & 12,37 \\
MCH & 1,0 & 25,22 & 15,61 & 40,83 & 5,09 \\
SAM & 1,0 & 22,72 & 20,23 & 42,94 & 6,30 \\
SAM/NS1 & 1,0 & 36,32 & 34,98 & 71,30 & 8,35 \\
\hline
\end{tabular}




\section{APÊNDICE}

\section{Circuito Elétrico Equivalente}

A Tabela B.1 mostra os resultados obtidos do ajuste dos dados pelo circuito equivalente de Randles modificado com CPE.

Nesta tabela é possível notar algumas características da plataforma impedimétrica:

- $R_{c t}$ : o aumento do valor da resistência à transferência de carga com a concentração de NS1 indica a interação da proteína com a SAM.

- $R_{s}$ : os valores da resistência da solução eletrolítica apresentaram poucas variações $( \pm 13 \Omega)$. As maiores mudanças se devem principalmente à adição do soro humano.

- CPE: assim como a resistência da solução, os valores obtidos da capacitância de fase constante se alteraram na adição do soro. Essa mudanças se devem ao fato do soro possuir uma composição diferente do tampão PBS.

- W: os valores da impedância de Warburg se mantivarem quase constante, com variações mínimas $\left( \pm 14 \cdot 10^{-4} \Omega\right)$.

- $\chi^{2}$ : os valores do qui-quadrado apresentam um aumento relacionado principalmemte à adição de componentes na superfície do eletrodo, como uma maior concentração de NS1 e o uso do soro. 
Tabela B.1: Resultados dos parâmetros do circuito de Randles obtidos para a curva analítica da EIE.

\begin{tabular}{|c|c|c|c|c|c|c|c|c|}
\hline Tampão PBS & & & & & & & & \\
\hline $\begin{array}{c}\text { NS1 } \\
(\mathrm{g} / \mathrm{mL}) \\
\end{array}$ & $\begin{array}{c}R_{c t} \\
(K \Omega)\end{array}$ & $\begin{array}{l} \pm R_{c t} \\
(\mathrm{~K} \Omega)\end{array}$ & $\begin{array}{l}R_{s} \\
(\Omega)\end{array}$ & $\begin{array}{c} \pm R_{s} \\
(\Omega)\end{array}$ & $\begin{array}{c}\text { CPE } \\
\left(10^{-7} \text { Mho }\right) \\
\end{array}$ & $\begin{array}{c} \pm \mathrm{CPE} \\
\left(10^{-8} \mathrm{Mho}\right)\end{array}$ & $\begin{array}{c}\text { W } \\
\left(10^{-4} \Omega\right)\end{array}$ & $\chi^{2}$ \\
\hline $1,0.10^{-11}$ & 3,74 & 0,02 & 129 & 1,42 & 2,04 & 0,81 & 3,49 & 0,07 \\
\hline $1,0.10^{-10}$ & 3,90 & 0,03 & 130 & 1,78 & 2,47 & 0,88 & 3,47 & 0,08 \\
\hline $1,0.10^{-9}$ & 3,88 & 0,03 & 129 & 1,59 & 1,91 & 0,77 & 3,49 & 0,09 \\
\hline $1,0.10^{-8}$ & 4,04 & 0,04 & 130 & 1,59 & 2,09 & 0,88 & 3,44 & 0,09 \\
\hline $1,0.10^{-7}$ & 4,09 & 0,04 & 130 & 1,64 & 2,10 & 0,92 & 3,43 & 0,10 \\
\hline $1,0.10^{-6}$ & 4,16 & 0,04 & 130 & 1,67 & 2,10 & 0,92 & 3,47 & 0,10 \\
\hline \multicolumn{9}{|l|}{ Soro $50 \%$} \\
\hline $1,0.10^{-11}$ & 2,97 & 0,03 & 135 & 2,10 & 1,81 & 1,24 & 3,53 & 0,14 \\
\hline $1,0.10^{-10}$ & 3,11 & 0,03 & 133 & 2,22 & 1,82 & 1,31 & 3,46 & 0,13 \\
\hline $1,0.10^{-9}$ & 3,22 & 0,04 & 134 & 2,33 & 1,84 & 1,36 & 3,49 & 0,13 \\
\hline $1,0.10^{-8}$ & 3,29 & 0,04 & 134 & 2,37 & 1,85 & 1,39 & 3,46 & 0,17 \\
\hline $1,0.10^{-7}$ & 3,32 & 0,04 & 132 & 2,41 & 1,87 & 1,45 & 3,48 & 0,18 \\
\hline $1,0.10^{-6}$ & 3,41 & 0,04 & 133 & 2,45 & 1,90 & 1,48 & 3,46 & 0,19 \\
\hline \multicolumn{9}{|l|}{ Soro $100 \%$} \\
\hline $1,0.10^{-11}$ & 3,12 & 0,03 & 142 & 2,14 & 1,78 & 1,24 & 3,37 & 0,13 \\
\hline $1,0.10^{-10}$ & 3,17 & 0,03 & 137 & 2,26 & 1,81 & 1,32 & 3,38 & 0,15 \\
\hline $1,0.10^{-9}$ & 3,27 & 0,04 & 141 & 2,37 & 1,80 & 1,34 & 3,35 & 0,16 \\
\hline $1,0.10^{-8}$ & 3,36 & 0,04 & 139 & 2,43 & 1,86 & 1,42 & 3,30 & 0,17 \\
\hline $1,0.10^{-7}$ & 3,45 & 0,04 & 141 & 2,49 & 1,86 & 1,43 & 3,30 & 0,17 \\
\hline $1,0.10^{-6}$ & 3,46 & 0,04 & 139 & 2,53 & 1,88 & 1,47 & 3,30 & 0,18 \\
\hline
\end{tabular}




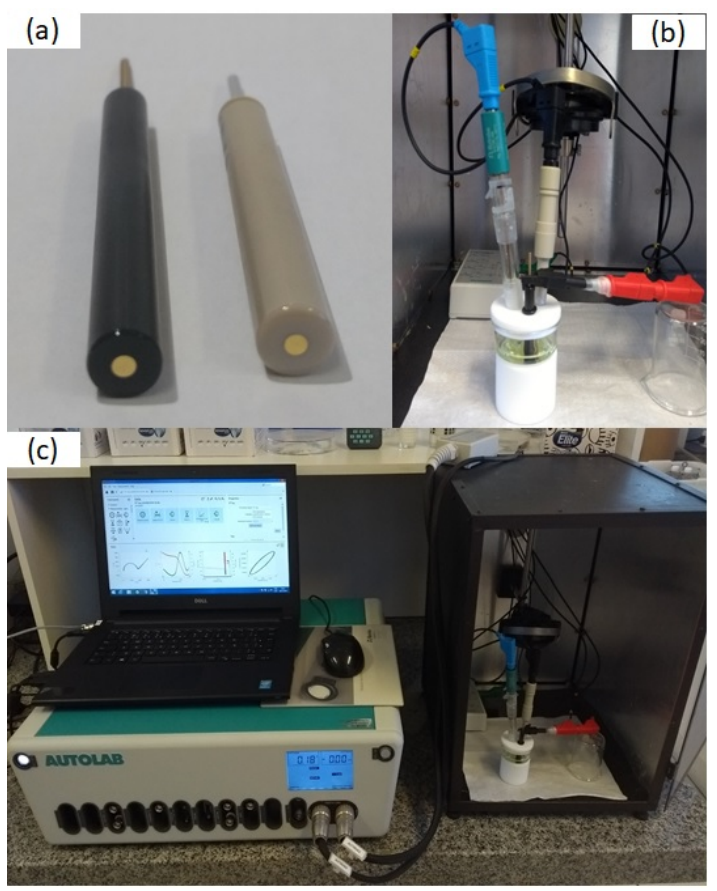

Figura B.1: Imagens do sistema montado: Eletrodo de trabalho (a); Célula eletroquímica (b); Plataforma de detecção (c).

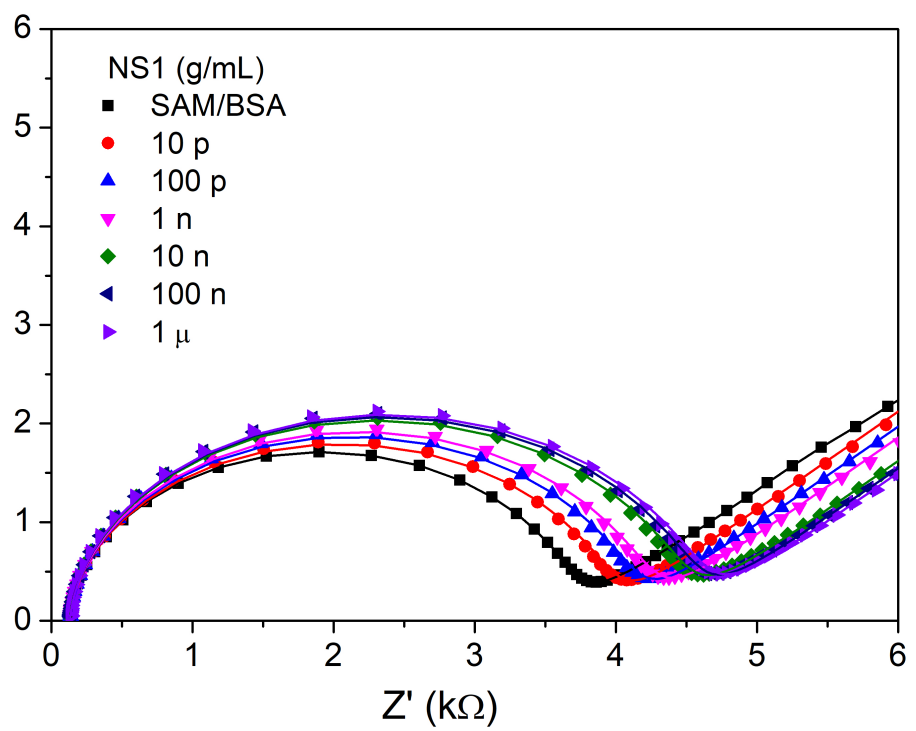

Figura B.2: Diagrama de Nyquist e o ajuste do circuito de Randles para a construção da curva analítica da EIE. 